\title{
UNITED STATES CONTRIBUTIONS TO THE SECOND INTERNATIONAL INDIAN OCEAN EXPEDITION (US IIOE-2)
}

\author{
Final \\ (23 October 2018)
}

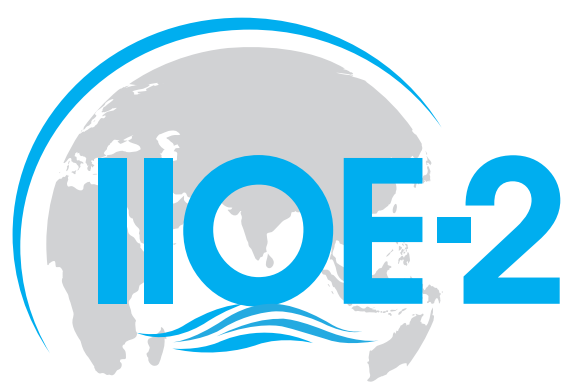

2nd International

Indian Ocean

Expedition

琶US Steering Committee

Hood, R. R., L. M. Beal, H. M. Benway, C. L. Chandler, V. J. Coles, G. A. Cutter, H. J. B. Dick, A. Gangopadhyay, J. I. Goes, S. E. Humphris, M. R. Landry, K. G. Lloyd, M. J. McPhaden, R. Murtugudde, B. Subrahmanyam, R. D. Susanto, L. D. Talley, J. D. Wiggert, C. Zhang (Eds.) 


\section{Preface}

The purpose of this document is to motivate and coordinate U.S. participation in the Second International Indian Ocean Expedition (IIOE-2) by outlining a core set of research priorities that will accelerate our understanding of geologic, oceanic, and atmospheric processes and their interactions in the Indian Ocean. These research priorities have been developed by the U.S. IIOE-2 Steering Committee based on the outcomes of an interdisciplinary Indian Ocean science workshop held at the Scripps Institution of Oceanography on September 11-13, 2017. The workshop was attended by 70 scientists with expertise spanning climate, atmospheric sciences, and multiple subdisciplines of oceanography. Workshop participants were largely drawn from U.S. academic institutions and government agencies, with a few experts invited from India, China, and France to provide a broader perspective on international programs and activities and opportunities for collaboration. These research priorities also build upon the previously developed International IIOE-2 Science Plan and Implementation Strategy. Outcomes from the workshop are condensed into five scientific themes: Upwelling, inter-ocean exchanges, monsoon dynamics, inter-basin contrasts, marine geology and the deep ocean. Each theme is identified with priority questions that the U.S. research community would like to address and the measurements that need to be made in the Indian Ocean to address them.

U.S. IIOE-2 research will significantly advance our knowledge of this under-sampled, yet heavily populated basin, providing an important scientific contribution to the larger international effort, and helping to create a lasting legacy on which future research can build. We encourage U.S. scientists from all relevant fields to collaborate and pursue new projects that address some of these key research questions.

US IIOE-2 Steering Committee (and contributing authors*), 2018:

Hood, R. R., L. M. Beal, H. M. Benway*, C. L. Chandler*, V. J. Coles*, G. A. Cutter, H. J. B. Dick, A. Gangopadhyay*, J. I. Goes, S. E. Humphris*, M. R. Landry, K. G. Lloyd, M. J. McPhaden, R. Murtugudde*, B. Subrahmanyam, R. D. Susanto, L. D. Talley, J. D. Wiggert, C. Zhang

Please cite as follows:

Hood, R. R., Beal, L. M., Benway, H. M., Chandler, C. L., Coles, V. J., Cutter, G. A., Dick, H. J. B., Gangopadhyay, A., Goes, J. I., Humphris, S. E, Landry, M. R., Lloyd, K. G., McPhaden, M. J., Murtugudde, R., Subrahmanyam, B., Susanto, R. D., Talley, L. D., Wiggert, J. D., Zhang, C. (2018) United States Contributions to the Second International Indian Ocean Expedition (US IIOE-2), 2018-08-02, DOI:10.1575/1912/10510, https://hdl.handle.net/1912/10510, 65 pp. 


\section{Acknowledgements}

This document has been compiled and edited based on contributions from the following individuals:

Anika Arora, Karl Banse, Chandranath Basak, Lisa Beal, Nina Bednarsek, Abderrahim Bentamy, Heather Benway, Subramanyam Bulusu, Antonio Busalacchi, Cynthia Chandler, James Cochran, Victoria Coles, Gregory Cutter, Eric D'Asaro, Andrew Delman, Henry Dick, Kyla Drushka, Eurico D'Sa, Richard Feely, Severine Fournier, Avijit Gangopadhyay, Catherin Garcia, Lata Gawade Velip, Chellappan Gnanaseelan, Joaquim Goes, Steven Goldstein, Ed Gorecki, Raleigh Hood, Xiaoyue Hu, Susan Humphris, Thomas Kilpatrick, Kolluru Krishna, Michael Landry, Alyse Larkin-Swartout, Tony Lee, Timothy Liu, Karen Lloyd, Michael Lomas, Alison MacDonald, Amala Mahadevan, John Marra, Adam Martiny, Michael McPhaden, Viviane Menezes, James Moffett, Raghu Murtugudde, Robert Pinkel, Rachel Pinker, Jill Reisdorf, Laure Resplandy, Isabella Rosso, V.V.S.S. Sarma, Hyodae Seo, Rui Shi, Janet Sprintall, Gowtham Subbarao, Dwi Susanto, James Swift, Lynne Talley, Veronica Tamsitt, Amit Tandon, Maria Vernet, Dongxiao Wang, He Wang, Peter Webster, Jerry Wiggert, Xiaosu Xie, Nan Zang, Chidong Zhang, Lei Zhou.

We thank the following organizations and programs for financial contributions, support and endorsement: the U.S. National Oceanic and Atmospheric Administration; the U.S. Ocean Carbon and Biogeochemistry program funded by the National Science Foundation and the National Aeronautics and Space Administration; the NASA Physical Oceanography Program; Scripps Institution of Oceanography; and the Indo-US Science and Technology Forum. 


\section{Table of Contents}

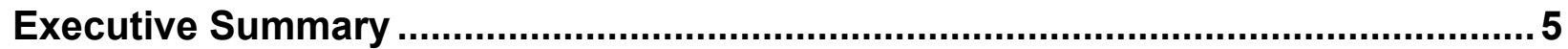

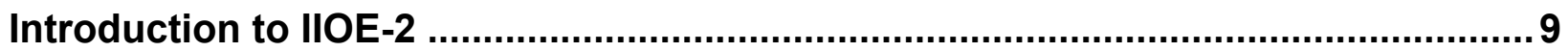

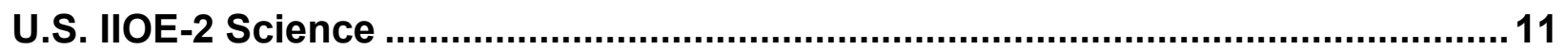

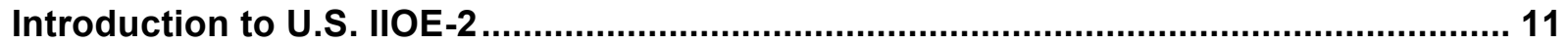

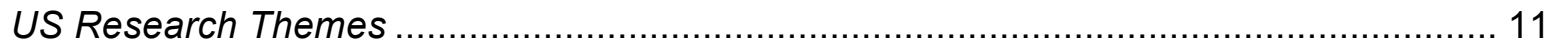

Theme 1: Physical, Biogeochemical and Ecological Dynamics of the Seychelles-Chagos

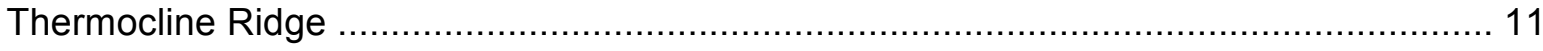

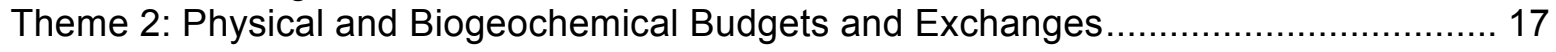

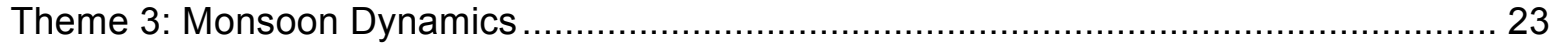

Theme 4: Physical, Biogeochemical and Ecological Contrasts Between the Arabian Sea

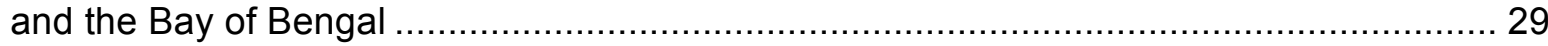

Theme 5: Marine Geology and Deep Ocean Biogeochemistry and Ecology ................... 37

5A) Crustal genesis, mantle processes, hydrothermal activity and the deep biosphere at the

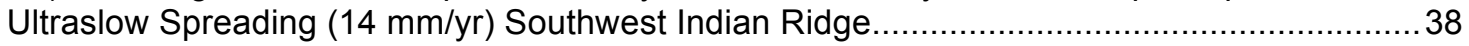

5B) Deep subsurface sediments of the Bengal and Indus Fans ...................................... 41

5C) Regional tectonics of the Northern Indian Ocean ........................................................ 43

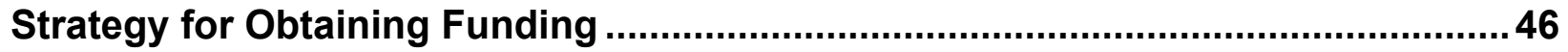

Training, Education and Outreach ...................................................................... 48

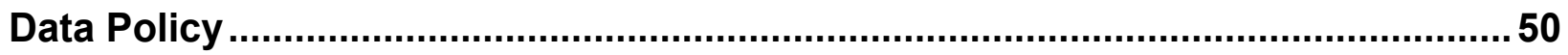

Leveraging and Coordination ............................................................................51

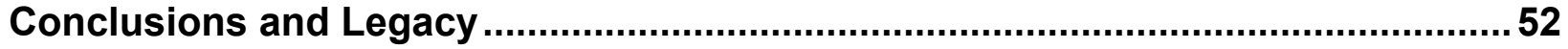

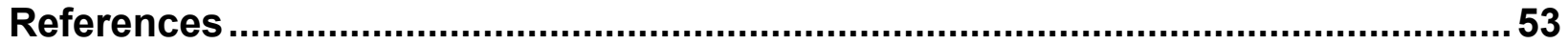

APPENDIX. ACRONYMS

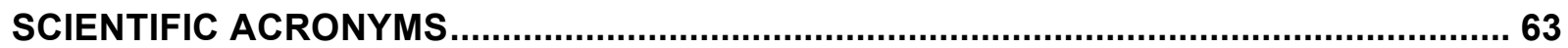

PROJECT, PROGRAM AND ORGANIZATIONAL ACRONYMS .................................... 64 


\section{Executive Summary}

The overarching goals of the second International Indian Ocean Expedition (IIOE-2) are to advance understanding of the geologic, oceanic, and atmospheric processes that drive climate, monsoon dynamics, extreme events, marine biogeochemical cycles, and ecosystems in the Indian Ocean. This understanding is required to predict the impacts of climate change, pollution, and increased fish harvesting on the Indian Ocean and its human populations, as well as the influence of the Indian Ocean on other components of the Earth System. Other goals of IIOE-2 include helping to build research capacity and improving availability and accessibility of oceanographic data from the region. Data, resources, and new understanding are fundamental to policy makers for the development of sustainable coastal zones, ecosystems, and fisheries management strategies in countries bordering Indian Ocean.

A Science Plan and an Implementation Strategy for IIOE-2 has already been developed by the international community, with sponsorship from the Intergovernmental Oceanographic Commission (IOC) and the Scientific Committee on Oceanic Research (SCOR). The international Science Plan is very broad, articulating many important scientific questions as potential research foci for national and international studies in the Indian Ocean. Planning and execution of contributions to IIOE-2 is well-underway in several countries.

To promote the development of a set of U.S. Indian Ocean research priorities that can leverage IIOE-2 activities a workshop was convened at the Scripps Institution of Oceanography on September 11-13, 2017, sponsored by the Ocean Carbon Biogeochemistry (OCB), the National Aeronautics and Space administration (NASA) Physical Oceanography program, the National Oceanic and Atmospheric Administration (NOAA), Scripps Institution of Oceanography (SIO), and the Indo-US Science and Technology Forum (IUSSTF). The goal of this workshop was to generate specific recommendations that articulate potential U.S.-led contributions to IIOE-2. Five priority research themes emerged:

Theme 1: Physical, Biogeochemical and Ecological Dynamics of the Seychelles-Chagos Thermocline Ridge (SCTR)

- What is the relative importance of local versus remote forcing on the threedimensional circulation of SCTR and how does this forcing vary on intraseasonal, seasonal, and interannual time scales?

- How do physical processes and related biogeochemical factors affect the seasonal cycle of primary productivity, the microbial food web and ecosystem dynamics?

- Is the prey of large tuna in the SCTR supported by advection and convergence from adjacent ocean waters or from local upwelling of nutrients that enhances primary and secondary productivity?

- Alternatively, could the presence of large numbers of tuna schools in the SCTR be related to spawning? 
Theme 2: Physical and Biogeochemical Budgets and Exchanges

- How does the Indian Ocean heat budget vary over timescales from seasonal to decadal?

- What is the role of the subtropical gyre, of the shallow and deep overturning cells, of mode water formation, and of the Indonesian Throughflow and the Agulhas system in basin-wide heat and nutrient budgets and their changes?

- How are the Indian Ocean heat and nutrient budgets linked to decadal variability of sea surface temperature, sea level, primary productivity and food web dynamics?

Theme 3: Monsoon Dynamics

- How do the multi-scale ocean dynamics and air-sea interactions in the tropical Indian Ocean influence variability and predictability of the monsoon on subseasonal to seasonal timescales?

- What are the root causes of biases and errors in key tropical regions in the stateof-the-art climate and Earth system models?

- What are the dominant low-frequency natural variability patterns and timescales in the Indian Ocean? How are the low-frequency phenomena in the Indian Ocean affected by the response in the Southern and Pacific oceans to global warming?

Theme 4: Physical, Biogeochemical, and Ecological Contrasts Between the Arabian Sea and Bay of Bengal

- What controls the source variability, local ventilation, biological oxygen demand, and biological and biogeochemical impacts of the two Northern Indian Ocean oxygen minimum zones (OMZs)?

- Are the Northern Indian Ocean OMZs uniquely sensitive to climate change? How will climate change impact the OMZs and, in particular, the interactions between monsoon intensity and timing, increased anthropogenic nutrients and carbon inputs, low oxygen and acidification?

- What are the spatial and temporal extents of nutrient limitations in the northern Indian Ocean? How do these limitations impact the microbial food web and primary production that fuels biological oxygen demand?

Theme 5: Marine Geology and Deep-Ocean Biogeochemistry and Ecology

- What controls the local and regional variability of mid-ocean ridge basalt and ridge tectonics at the ultraslow spreading Southwest Indian Ridge, and how does this reflect mantle prehistory? How is the rock-hosted subsurface biosphere at the Southwest Indian Ridge impacted by mantle below ocean crust in magmatic segments?

- How does chemical exchange during hydrothermal circulation at the Southwest Indian Ridge affect the biogeochemistry and microbial ecology of the deep Indian Ocean water column and subsurface biosphere? How do different rock substrates affect the nature and composition of hydrothermal mineral deposits? 
- Do potentially high microbial cell numbers in the Bengal and/or Indus fans alter global estimates of the size of the marine deep subsurface biosphere? How do subsurface microbial populations respond to long-term exposure to elevated organic matter content in an anoxic environment?

- How did the diffuse plate boundary starting from the Central Indian Ridge to the Sunda subduction zone evolve? How and where are micro-continents like Elan Bank and Southern Kerguelen Plateau split from the Indian subcontinent? What is the structure and evolution of the $85^{\circ} \mathrm{E}$ Ridge? What is the nature of crust beneath the Bangladesh Margin?

\section{Strategy for Obtaining Funding}

The funding model for U.S. IIOE-2 will follow that for the ongoing GEOTRACES program (a collaborative multi-national program to investigate the global marine biogeochemical cycles of trace elements and their isotopes): Coordinated proposals will be submitted to both private and federal funding agencies. The U.S. IIOE-2 Steering Committee will help motivate and coordinate proposal development and submission.

Scientists pursuing research under Theme 1 should participate in the ongoing South Korean and U.S. bilateral planning process that is focused on the Seychelles-Chagos Thermocline Ridge, with potential proposal submissions to U.S. federal agencies (NSF, NOAA and NASA) anticipated in 2019.

Scientists pursuing research related to Theme 2 are encouraged to contact the U.S. IIOE-2 Steering Committee for help coordinating collaborations, proposal development, and submission. Relevant units within NSF include the Physical and Chemical Oceanography programs. Relevant units within NOAA include the Office of Oceanic and Atmospheric Research and the Climate Program Office.

Scientists pursuing research related to Theme 3 should formulate proposals for submission to NSF's Atmospheric and Geospace Sciences, Earth Sciences, and Physical Oceanography programs. Submissions to NOAA's Office of Oceanic and Atmospheric Research and the Climate Program Office, and also to NASA's Earth Science Division are also encouraged. Opportunities for ONR funding can be ascertained by contacting the relevant program managers.

Theme 4 is particularly relevant to OCB, which is supported by the NSF Chemical and Biological Oceanography programs and NASA's Ocean Biology and Biogeochemistry program. Scientists pursuing research related to Theme 4 are encouraged to contact the US IIOE-2 Steering Committee for help coordinating collaborations. Coordinated proposal submissions in 2018 and 2019 are strongly encouraged.

Scientists pursuing research related to Theme 5 should formulate proposals for submission to NSF's Marine Geology and Geophysics and Chemical and Biological Oceanography programs. The U.S. IIOE-2 Steering Committee will establish a subcommittee dedicated to motivating and coordinating proposal submissions under this theme. 
Scientists are also encouraged to seek funding to support U.S. IIOE-2 research through private sources, for example, the Moore Foundation and the Schmidt Ocean Institute.

It is important to emphasize that U.S. proposals that do not fall under the five U.S. research themes should also be considered for funding as part of U.S. IIOE-2.

\section{Training, Education and Outreach}

U.S. IIOE-2 projects should include training, education and outreach components that build on collaborative expertise and physical resources from within and outside the Indian Ocean region. These components might also be linked to ongoing capacity development programs in the Indian Ocean. IOC, SCOR and POGO (Partnership for Observation of the Global Oceans) are pursuing a variety of international training, education, and outreach activities under IIOE-2 that could be leveraged by U.S.-funded efforts.

Through these efforts, U.S. participants in IIOE-2 can help build research capacity in Indian Ocean rim nations and promote the long-term sustainability of this capacity.

\section{Leveraging and Coordination}

U.S. IIOE-2 will build upon past and ongoing U.S.-funded research programs such as the ONR-funded ASIRI (Air-Sea Interaction Regional Initiative), MISO-BOB (Oceanic Control of Monsoon Intra-seasonal Oscillations in the Tropical Indian Ocean and the Bay of Bengal) and NASCar (Northern Arabian Sea Circulation-autonomous research) projects, the NOAA-funded Research Moored Array for African-Asian-Australian Monsoon Analysis and Prediction (RAMA) mooring array measurements in the tropical and subtropical Indian Ocean, and the NSF-funded Agulhas System Climate Array (ASCA) in the southwestern Indian Ocean. U.S. IIOE-2 will also leverage International programs such as the Indian Ocean Observing System (IndOOS), GEOTRACES, the Global Ocean Ship-Based Hydrographic Investigations Program (GO-SHIP), the International Ocean Discovery Program (IODP) and InterRidge (an international organization that promotes interdisciplinary, international studies of oceanic spreading centers). Each of these programs has a significant U.S. component. U.S. IIOE-2 will also take full advantage of satellite measurements that can help characterize physical and biological variability in the ocean and on adjacent landmasses.

Coordination among U.S.-funded efforts and with other national and international activities will be vital to the success of U.S. IIOE-2. This coordination will be facilitated by the U.S. IIOE-2 Steering Committee, and by US representation on the international IIOE-2 Steering Committee.

\section{Conclusions and Legacy}

Promotion, coordination, and integration of oceanographic, atmospheric and geologic research in the Indian Ocean by US IIOE-2 will advance knowledge of this undersampled, highly populated basin, leveraging, and contributing to, the larger international 
effort. The U.S. research foci on upwelling, inter-ocean exchanges, monsoon dynamics, inter-basin contrasts, and marine geology and the deep ocean will significantly expand the scope of the international IIOE-2 effort, helping to create a lasting legacy on which improved understanding, predictability, and sustainable management strategies can build. Products and partnerships that emerge from U.S. research activities will inform future planning of regional and basin-wide programs, and international collaborations. In the global context, U.S. IIOE-2 will facilitate the development of scientific infrastructure and human resources in Indian Ocean rim countries, while also inspiring a new generation of U.S. scientists to be experts of the Indian Ocean and its role in the global ocean and earth system.

\section{Introduction to IIOE-2}

More than 50 years ago the Scientific Committee on Ocean Research and the Intergovernmental Oceanographic Commission of UNESCO identified that the Indian Ocean was one of the least studied ocean basins. To address this gap in knowledge, SCOR and IOC motivated one of the greatest oceanographic expeditions of all time, the International Indian Ocean Expedition (IIOE). The IIOE was a 6-year expedition (19601965) with forty-six research vessels participating under fourteen different national flags. IIOE proved to be a remarkable success, providing much of the scientific foundation for our modern understanding of the Indian Ocean. However, the Indian Ocean remains one of the most poorly sampled regions of the world ocean. Today, more than one quarter of the world's population lives in the Indian Ocean region (Alexander et al., 2012), and the populations of most Indian Ocean rim nations are increasing rapidly. These increases give rise to multiple stressors in both coastal and open-ocean environments. Combined with warming and acidification due to global climate change, regional stressors are resulting in loss of biodiversity in the Indian Ocean and changes in the phenology and biogeography of many species. These pressures have generated an urgent need to understand and predict changes in the Indian Ocean, but the measurements and knowledge needed to take on these challenges are lacking. In response, SCOR, IOC and IOGOOS (Indian Ocean Global Ocean Observing System) have motivated a second International Indian Ocean Expedition (IIOE-2). An international Science Plan (Hood et al., 2015) and an Implementation Strategy (IPC, 2015) have been developed for IIOE-2, and national research initiatives are wellunderway in several countries.

The overarching goals of IIOE-2 are to advance understanding of the interactions among geologic, oceanic, and atmospheric processes that give rise to the complex physical dynamics of the Indian Ocean region, and determine how these dynamics affect climate, extreme events, marine biogeochemical cycles, ecosystems, and human populations. This understanding is needed to predict the impacts of climate change, pollution, and increased fish harvesting on the Indian Ocean and its surrounding nations, as well as the influence of the Indian Ocean on other components of the Earth System. New understanding is also fundamental to policy makers for the development of sustainable coastal zone, ecosystem, and fisheries management strategies. Other 
goals of IIOE-2 include helping to build research capacity and improving availability and accessibility of oceanographic data from the region.

The IIOE-2 Science Plan is very broad, including atmospheric, oceanographic and geologic research that extends from coastal environments to the deep ocean and trophic levels ranging from bacteria and phytoplankton to top predators and humans. The Plan is structured around six scientific themes (see Table 1). Each theme includes a set of questions that need to be addressed to improve understanding of the physical forcing that drives variability in marine biogeochemical cycles, ecosystems, and fisheries in the Indian Ocean, and to develop the capacity to predict how this variability will impact human populations in the future. It is anticipated that national contributions will focus on specific aspects of the international plan and/or complement and expand its scope. Planning and execution of national contributions to IIOE-2 is well-underway in several countries.

\section{Table 1: IIOE-2 International Science Plan Research Themes}

\begin{tabular}{|c|c|}
\hline Theme 1: Human Impacts & $\begin{array}{l}\text { How are human-induced ocean stressors impacting the biogeochemistry and ecology of the } \\
\text { Indian Ocean? How, in turn, are these impacts affecting human populations? }\end{array}$ \\
\hline $\begin{array}{l}\text { Theme 2: Boundary current } \\
\text { dynamics, upwelling variability } \\
\text { and ecosystem impacts }\end{array}$ & $\begin{array}{l}\text { How are marine biogeochemical cycles, ecosystem processes and fisheries in the Indian } \\
\text { Ocean influenced by boundary currents, eddies and upwelling? How does the interaction } \\
\text { between local and remote forcing influence these currents and upwelling variability in the } \\
\text { Indian Ocean? How have these processes and their influence on local weather and climate } \\
\text { changed in the past and how will they change in the future? }\end{array}$ \\
\hline $\begin{array}{l}\text { Theme 3: Monsoon Variability } \\
\text { and Ecosystem Response }\end{array}$ & $\begin{array}{l}\text { What factors control present, past and future monsoon variability? How does this variability } \\
\text { impact ocean physics, chemistry and biogeochemistry in the Indian Ocean? What are the } \\
\text { effects on ecosystems, fisheries and human populations? }\end{array}$ \\
\hline $\begin{array}{l}\text { Theme 4: Circulation, climate } \\
\text { variability and change }\end{array}$ & $\begin{array}{l}\text { How has the atmospheric and oceanic circulation of the Indian Ocean changed in the past } \\
\text { and how will it change in the future? How do these changes relate to topography and } \\
\text { connectivity with the Pacific, Atlantic and Southern oceans? What impact does this have on } \\
\text { biological productivity and fisheries? }\end{array}$ \\
\hline $\begin{array}{l}\text { Theme 5: Extreme events and } \\
\text { their impacts on ecosystems and } \\
\text { human populations }\end{array}$ & $\begin{array}{l}\text { How do extreme events in the Indian Ocean impact coastal and open-ocean ecosystems? } \\
\text { How will climate change impact the frequency and/or severity of extreme weather and } \\
\text { oceanic events, such as tropical cyclones and tsunamis in the Indian Ocean? What are the } \\
\text { threats of extreme weather events, volcanic eruptions, tsunamis, combined with sea level } \\
\text { rise, to human populations in low-lying coastal zones and small island nations of the Indian } \\
\text { Ocean region? }\end{array}$ \\
\hline $\begin{array}{l}\text { Theme 6: Unique geological, } \\
\text { physical, biogeochemical, and } \\
\text { ecological features of the Indian } \\
\text { Ocean }\end{array}$ & $\begin{array}{l}\text { What processes control the present, past, and future carbon and oxygen dynamics of the } \\
\text { Indian Ocean and how do they impact biogeochemical cycles and ecosystem dynamics? How } \\
\text { do the physical characteristics of the southern Indian Ocean gyre system influence the } \\
\text { biogeochemistry and ecology of the Indian Ocean? How do the complex tectonic and } \\
\text { geologic processes, and topography of the Indian Ocean influence circulation, mixing and } \\
\text { chemistry and therefore also biogeochemical and ecological processes? }\end{array}$ \\
\hline
\end{tabular}




\section{U.S. IIOE-2 Science}

\section{Introduction to U.S. IIOE-2}

The U.S. IIOE-2 Steering Committee was formed in mid-2015 to promote, coordinate, and implement a U.S. component of IIOE-2. To develop and articulate potential U.S.-led contributions, the committee convened an interdisciplinary Indian Ocean science workshop at the Scripps Institution of Oceanography on 11-13 September 2017. This workshop was attended by 70 scientists, mostly from U.S. academic institutions and government agencies, but also from India, China and France. Workshop presentations were focused on highlighting new research activities, as well as existent and upcoming observing and modeling tools that could motivate U.S. research in the Indian Ocean. Subsequent discussions focused on prioritizing the measurement of important Indian Ocean phenomena and improved process understanding.

The overarching goals of the U.S. contribution to IIOE-2 are synonymous with the international effort: To advance our understanding of geologic, oceanic and atmospheric processes, and determine how they affect climate, extreme events, monsoon dynamics, marine biogeochemical cycles, ecosystems, and human populations.

Five research themes emerged from the U.S. Indian Ocean science workshop. Each theme includes a set of core scientific questions and the measurements necessary to address them.

\section{US Research Themes}

\section{Theme 1: Physical, Biogeochemical and Ecological Dynamics of the Seychelles-Chagos Thermocline Ridge}

\section{Introduction}

The Seychelles-Chagos Thermocline Ridge (SCTR, Vialard et al., 2009) is characterized by upwelling, a shallow thermocline, and a thin mixed layer $(\sim 30 \mathrm{~m})$. As a result, sea surface temperatures and air-sea fluxes over the SCTR are highly sensitive to local and remote forcing on seasonal to interannual timescales (Hermes and Reason, 2008; Yokoi et al., 2008; McPhaden and Nagura, 2014). The ridge spans the southwestern tropical Indian Ocean in the latitude band $5-15^{\circ} \mathrm{S}$ (Fig. 1.1) and is sustained by cyclonic wind stress curl. Its northern edge marks the southernmost latitudes of monsoon-driven flow in the Indian Ocean, to the south of which a steadier trade wind regime prevails (Fig. 1.1). The Intertropical Convergence Zone is located over the SCTR during boreal winter and migrates northward to the Indian subcontinent as the year progresses, where it is the source of heavy precipitation during the summer monsoon. 


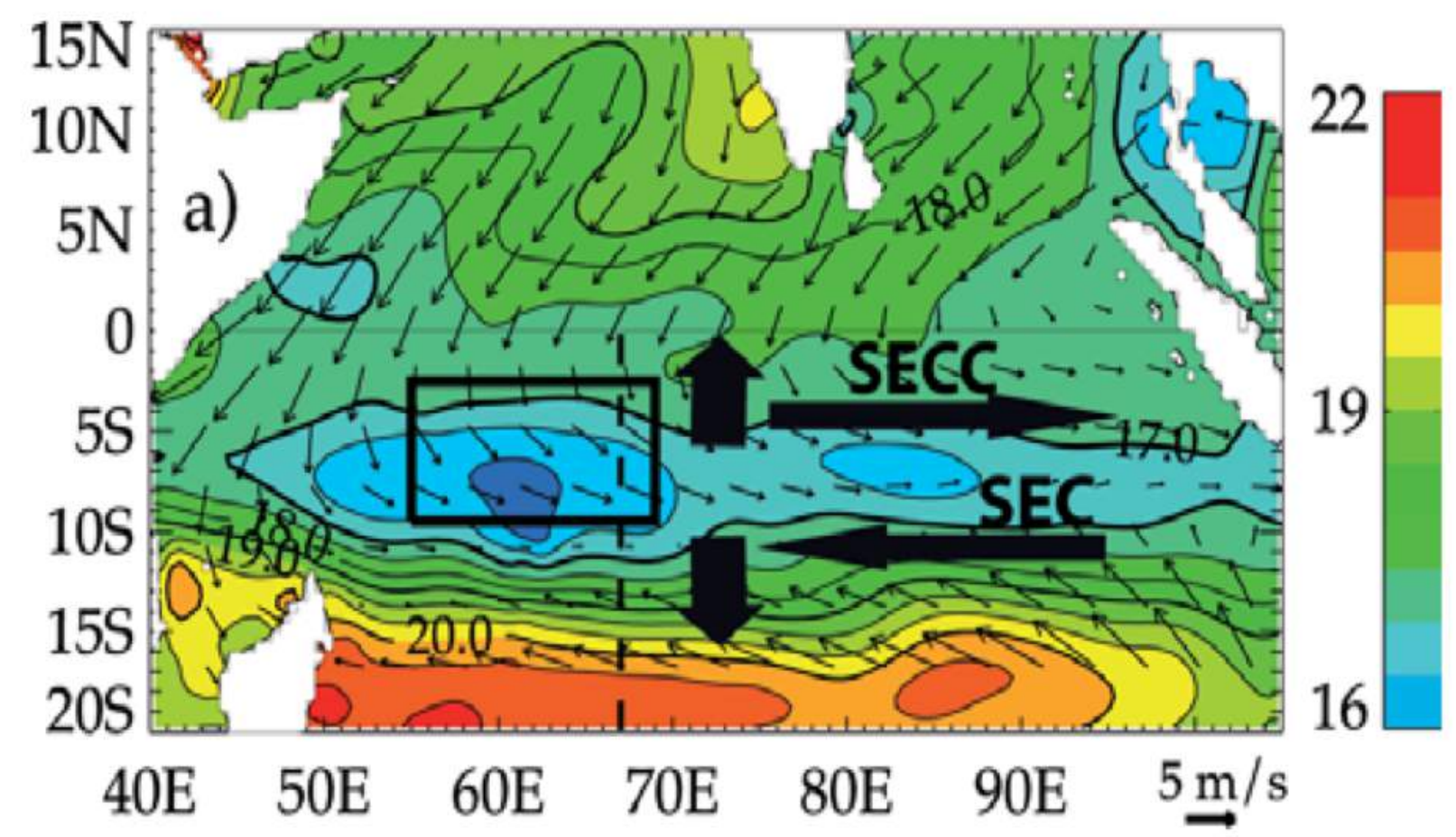

Figure 1.1: Climatological surface winds and 0-300-m average ocean temperature in JanFeb. The thick black arrows indicate the surface flow induced by wind that promotes upwelling and leads to the SCTR formation. The arrows marked SEC and SECC indicate the south equatorial current and south equatorial countercurrent. Adapted from Figure 1 in Vialard et al. (2009), Copyright American Meteorological Society. Used with permission.

Upwelling along the SCTR affects sea surface temperature (SST, Fig. 1.2), biogeochemistry (Fig. 1.2), and fisheries (Fig. 1.3), and drives strong ocean-atmosphere coupling. Unlike in the Pacific and Atlantic oceans, upwelling centers in the monsoondominated Indian Ocean are found in off-equatorial regions because the mean winds along the equator are westerly instead of easterly (Wang and McPhaden, 2017). The SCTR is the most geographically extensive and persistent of these upwelling regions, which include the Somali coast, the Sri Lankan Dome, and the coastal zone off Sumatra and Java. These regions form the ascending branch of the Indian Ocean shallow overturning cell, which is balanced by subduction in the Southern Hemisphere subtropical gyre. Horizontal flow circulates cyclonically around the SCTR, with the westward South Equatorial Current (SEC) to the south and the eastward South Equatorial Countercurrent (SECC) to the north (Fig. 1.1). The SEC carries most of the Indonesian Throughflow (ITF) forming a conduit from the Pacific Ocean towards the Atlantic Ocean via the Agulhas Current.

Intraseasonal to interannual SST variations are strong in the SCTR because the shallow mixed layer is sensitive to changes in air-sea heat fluxes, upwelling, vertical mixing, and horizontal advection (Foltz et al., 2010). On intraseasonal time scales SST responds to and feeds back on the Madden-Julian Oscillation (MJO) (Vialard et al., 2008), which intensifies over this region (Zhang and Ling 2017). On interannual timescales, large SST variations are associated with the Indian Ocean Dipole (IOD; Saji et al., 1999; 
Webster et al., 1999). These year-to-year SST variations affect both the frequency of tropical storms in the southwestern Indian Ocean (Xie et al., 2002a,b) and Indian summer monsoon rainfall (Izumo et al., 2008). The tuna fishery is well developed in the SCTR region (Fig. 1.3); however, during positive IOD events when upwelling weakens, tuna migrate eastward, presumably towards more favorable foraging grounds off Java and Sumatra (Fig. 1.3, Robinson et al., 2010).
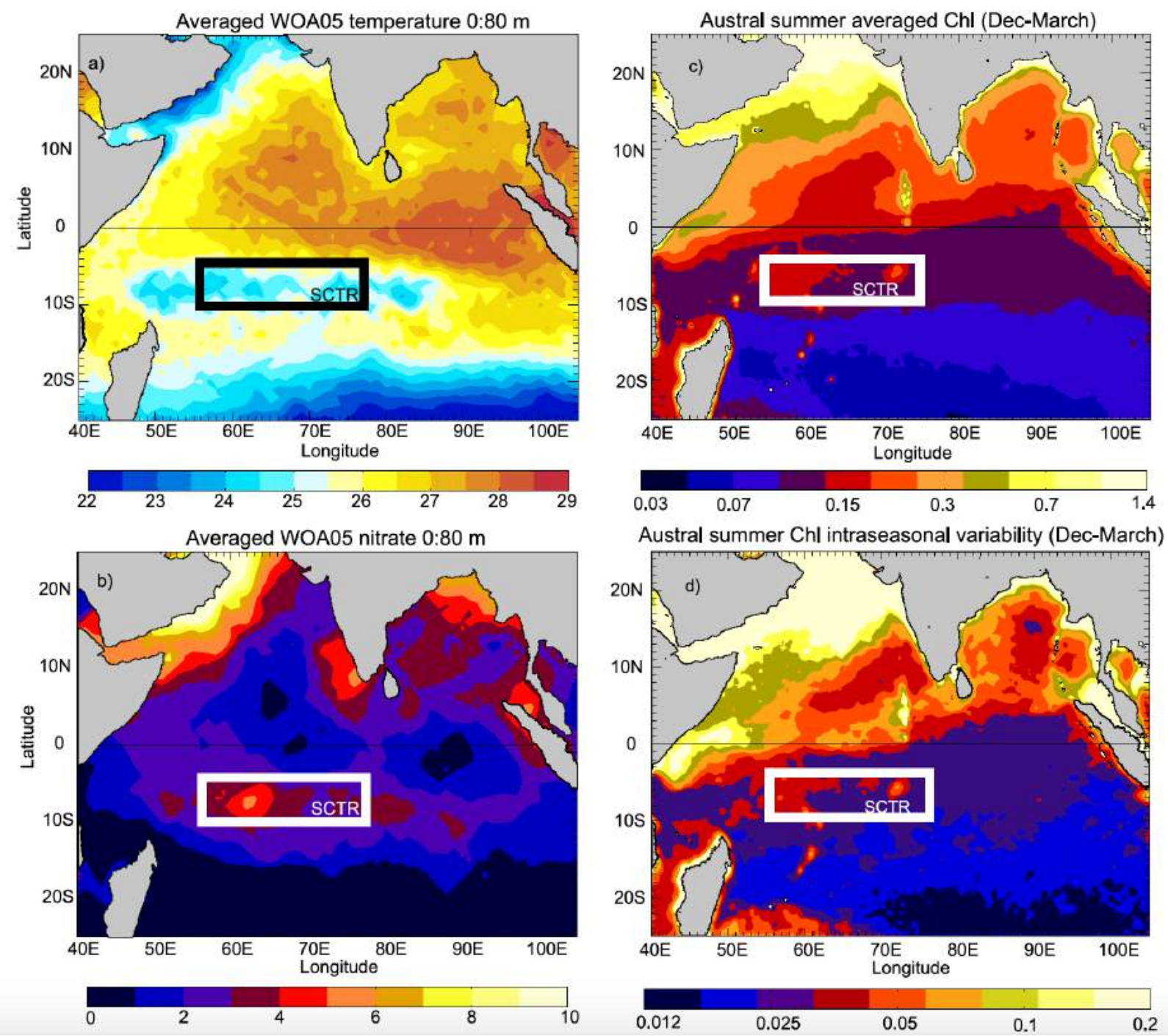

Austral summer Chl intraseasonal variability (Dec-March)

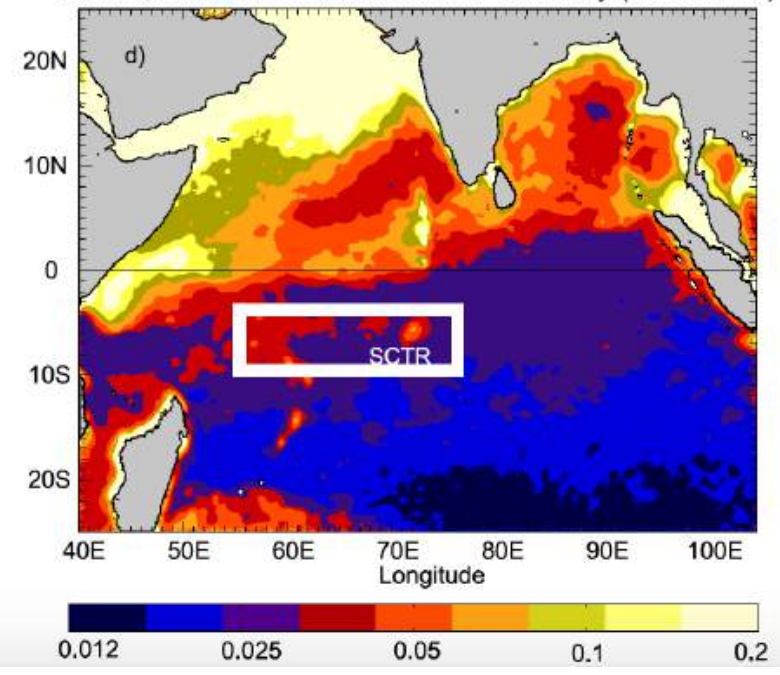

Figure 1.2 Annual WOA05 (a) temperature and (b) nitrate concentration (in mmol $\mathrm{N} \mathrm{m}^{\wedge}-3$ ) averaged between the surface and $80 \mathrm{~m}$ in the Indian Ocean. (c) SeaWiFS seasonal mean during austral summer (December-March) ( $\left.\mathrm{mg} \mathrm{m}^{\wedge}-3\right)$. (d) Intraseasonal variability of SeaWiFS Chl during austral summer estimated by the averaged RMS of $\left(\mathrm{Chl}-\mathrm{Chl}^{*}\right)$ between December and March of years 1998-2007. Figure 1 from Resplandy et al. (2009). Used with permission from John Wiley and Sons, Inc.

Observational studies have documented concentrated tuna fishing activities at locations where surface phytoplankton blooms had been observed in satellite observations 2-3 weeks previously (Fonteneau et al. 2008), demonstrating a strong connection between the food webs that respond to SCTR blooms and the prey required by large tuna. In contrast, biogeochemical modeling results indicate that neither phytoplankton biomass 
nor carbon export from the euphotic zone change significantly in response to seasonal and interannual variability of the SCTR thermocline depth (Resplandy et al., 2009). These contrasting results represent a paradox in the current understanding of ecological dynamics in the SCTR upwelling region, which can neither be so subtle as to produce no biogeochemical signals from the episodic nutricline intrusions into surface waters, nor so strong and efficient as to produce an almost instantaneous population response of the large long-lived prey that tuna consume.
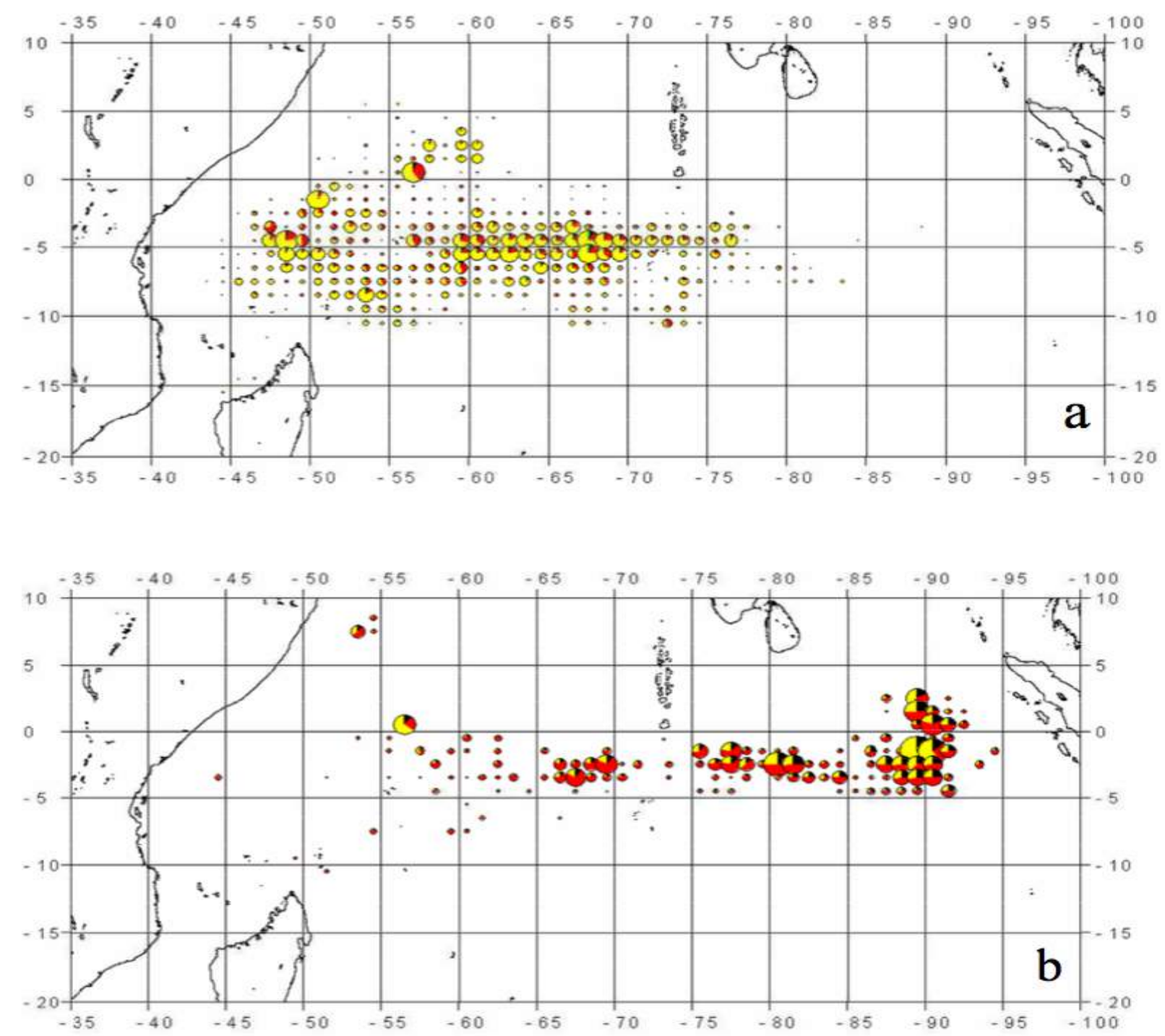

Figure 1.3: Tuna catch in the Indian Ocean during the 1997/1998 IOD event (bottom panel) compared to catch in normal years (top panel). From Robinson et al. (2010), Copyright InterResearch 2010.

\section{Scientific Motivation}

The SCTR is a phenomenon that is unique to the Indian Ocean - a consequence of the meridional asymmetry in the Indian Ocean circulation that arises as a result of monsoon 
forcing. This feature strongly influences atmospheric convection in both the Indian and Pacific oceans via initiation of the MJO and also creates an important foraging ground for tuna. Yet the current understanding of the dominant physics of SCTR variability is poor and the biogeochemical and ecological dynamics are completely unknown. Moreover, sea level has been falling (Han et al., 2010) and the thermocline shoaling (Alory et al., 2007) in the SCTR region in association with a trend towards rising SSTs in the Indian Ocean since the 1960s. These trends are likely due to changes in atmospheric circulation in response to anthropogenic greenhouse gas forcing (Dong et al., 2014). How future global warming may affect the sensitivity of the SCTR and its impacts on weather variability, marine biogeochemistry, and fisheries is uncertain. Three challenging scientific issues need to be addressed: 1) the dynamics of the SCTR and its interaction with the atmosphere require targeted observational and modeling studies in order to better predict how the SCTR and its impact on weather and climate in the Indian and Pacific oceans will change in the future; 2) a first-order characterization of the biogeochemical and ecological dynamics of the SCTR is needed, along with an understanding of how forcing at intraseasonal, seasonal, and interannual timescales affects higher trophic levels; and 3) development of predictive models is required for understanding how ecosystem functioning and fisheries will respond to changes in the physical environment and to future climate change.

\section{Societal Relevance}

Through strong ocean-atmosphere coupling, the SCTR influences the frequency of tropical storms in the southwestern Indian Ocean and Indian summer monsoon rainfall. SCTR variability also affects regional biogeochemistry and fisheries. Recent yellowfin tuna stock assessments indicate that this fishery is subject to overfishing, driven by unsustainable catches and low recruitment levels, as estimated by models (IOTC, 2017). However, these assessments are not informed by an understanding of the food web dynamics of the SCTR. Hence, observations focused on the physical, biogeochemical, and ecological dynamics of the SCTR are needed to better predict tropical storms, MJO, and monsoon rainfall, and to elucidate the connection between the marine food web and the prey required by large tuna in order to improve management of the fishery. These studies will provide greater insight into how the SCTR influences weather, the marine ecosystem and, ultimately, fisheries and human populations around the Indian Ocean rim.

\section{Scientific Questions}

The U.S. IIOE-2 research strategy on the Seychelles-Chagos Thermocline Ridge should involve coordinated interdisciplinary studies that focus on the following fundamental questions to advance the integrated understanding of the physical, biogeochemical, and ecological dynamics of the region. What is the relative importance of local versus remote wind stress forcing on the three-dimensional circulation of SCTR and its interaction with the atmosphere, and how does this forcing vary on intraseasonal, seasonal, and interannual timescales? What are the rates of upwelling in the Seychelles-Chagos Thermocline Ridge, and how does this upwelling affect SST, nutrient supply, species composition and productivity of the lower food web, 
nutrient, carbon cycling and budgets, and higher trophic levels (especially the tuna fishery)?

There is a pronounced seasonal cycle of Chl-a in the SCTR, with a maximum in August at a time when SST is at its coldest and wind speeds are highest. However, this is the time of year when the mixed layer, thermocline, and presumably the nutricline, are deepest. The seasonally cool SSTs are related to enhanced wind-driven vertical mixing. How do physical processes and related biogeochemical factors affect the subseasonal to seasonal variability of primary productivity, the microbial food web and ecosystem dynamics? How will global warming affect stratification and upwelling in the SCTR, and what will its impacts be on sea level, SST, nutrient and carbon budgets, ocean acidification and ecosystems in the region?

A specific focus is needed on improving understanding of the SCTR food web dynamics and higher trophic level responses. Is the prey required by large tuna in the SCTR supported by local upwelling of nutrients that enhances primary and secondary productivity? Or does the thermocline ridge act to concentrate larger prey that are transported to the area from adjacent ocean regions, making them available to top predators at higher densities? Alternatively, could the presence of large numbers of tuna schools in the SCTR be related to spawning?

\section{Implementation}

Addressing scientific questions in the SCTR will benefit from a variety of satellite measurements, including those for Sea Surface Temperature (SST), Sea Surface Salinity (SSS), sea level, winds, ocean color, and rainfall. Complementing these satellite data are measurements from the Indian Ocean Observing System (IndOOS) for temperature, salinity, velocity, air-sea fluxes of heat, fresh water and momentum, surface air pressure, and biogeochemical measurements (chlorophyll fluorescence, particle backscatter, $\mathrm{pCO}_{2}$ and air-sea $\mathrm{CO}_{2}$ flux, $\mathrm{pH}$ ). An IndOOS Decadal Review, which was led by the CLIVAR/GOOS (Climate Variability and Predictability / Global Ocean Observing System) Indian Ocean Regional Panel and will be published in early 2019, will recommend expanded deployment of biogeochemical sensors on the RAMA (McPhaden et al., 2009) moorings and expanded biogeochemical Argo deployments in the Indian Ocean basin. Research vessels, including those servicing RAMA moorings, could provide platforms for specialized measurements to test hypotheses related to SCTR variability and its impacts on climate, ecosystems and fisheries. Forced ocean models will also be valuable for studies of physical and coupled biophysical processes in the SCTR. Coupled climate models can be used to address recent and future trends in the region under various greenhouse gas forcing scenarios.

Focused U.S.-led research cruises are needed to conduct critical, multi-disciplinary measurements to address the scientific questions outlined above. Shipboard studies that address existing measurement deficiencies in upper ocean (500 meters) physical processes related, for example, to atmospheric forcing variability (wind speed profiles, air temperature and humidity), air-sea interaction (heat and momentum flux) and upperocean mixing (temperature and salinity, and microstructure profiles), can help provide insight into the relative importance of local versus remote wind-stress forcing on the 
three-dimensional circulation of SCTR. Shipboard studies can also help constrain estimates of upwelling in the SCTR and the impacts of upwelling on SST (3-dimensional Acoustic Doppler Current Profiler (ADCP) velocity and hydrographic surveys that include nutrient, trace metal and chlorophyll/pigment measurements). In addition, shipboard studies should be motivated to address the hypothesis that the thermocline ridge may function as a concentration center for larger prey that are transported to the area from adjacent ocean regions (primary production and export variability, and trophic transfer). In this regard, large stocks of mesopelagic fish are thought to occur in the Arabian Sea to the north of the SCTR and off Somalia to the west (Kinzer et al., 1993; Tsarin and Boltachev, 2006), but have not been assessed systematically in the region, as they could be, for example, by trawl surveys combined with modern acoustic measurements. Shipboard experimental studies that address the measurement deficiencies in primary production, nutrient, trace metal and light responses and limitations, new production and carbon export, microbial community structure, food-web dynamics, carbonate system parameters and biogeochemical process indices are also needed to develop and validate regional models that can assess the relative importance of in situ productivity versus transport mechanisms in explaining the system's unique coupling to higher trophic levels, the implications of SCTR dynamics to Indian Ocean biogeochemistry and their potential vulnerabilities to climate change. Behavioral and spawning/larval studies are also needed to determine whether or not the presence of large numbers of tuna schools in the SCTR could be related to spawning (e.g., net tows to determine presence/absence of tuna larvae).

\section{Theme 2: Physical and Biogeochemical Budgets and Exchanges}

\section{Introduction}

The redistribution of heat away from the equator and towards the poles by the oceans is an important component of the climate system, acting to moderate Earth's climate on a global scale. In the Indian Ocean, meridional heat export has been estimated to be greater than in any other region (Fig. 2.1; Lumpkin \& Speer, 2008; Hernández-Guerra \& Talley, 2016), due in large part to the low-latitude geography of the basin and to the tropical influx of heat from the Pacific. Moreover, the heat content of the Indian Ocean has increased more rapidly than in any other ocean basin over the past twenty years (e.g. Cheng et al., 2017). However, the handful of available estimates of the Indian Ocean heat budget are subject to large uncertainty (e.g., Hernández-Guerra \& Talley, 2016) and do not capture variability on any time scale; hence, it is difficult to predict how Indian Ocean heat content will change in the future.

The heat budget of the Indian Ocean is dominated by a tropical inflow of warm water from the Pacific via the Indonesian Seas (Fig. 2.2), by the warm Agulhas Current and its leakage into the Atlantic (Fig. 2.3), and by shallow and deep overturning cells, related to subduction of mode waters near the subtropical front and to upwelling of Antarctic Bottom Waters. The Indian Ocean exports a large amount of heat that balances heat loss in both the Southern and Atlantic oceans as part of the global thermohaline circulation (Fig. 2.1; Talley, 2013). Convergence and divergence of heat within the 
Indian basin (Bryden \& Beal, 2001; Lumpkin \& Speer, 2007; Han et al., 2014) affects ocean heat content (Roberts et al., 2017), stratification, and sea level. In turn, these physical changes in the ocean can influence the atmosphere and extreme weather through surface fluxes and dynamical coupling. They also influence the marine food web, due to concomitant changes in the oceanic exchanges of nutrients (Ayers et al., 2014) and due to the effect of temperature and stratification on upper ocean nutrient and oxygen levels (Roxy et al., 2016).

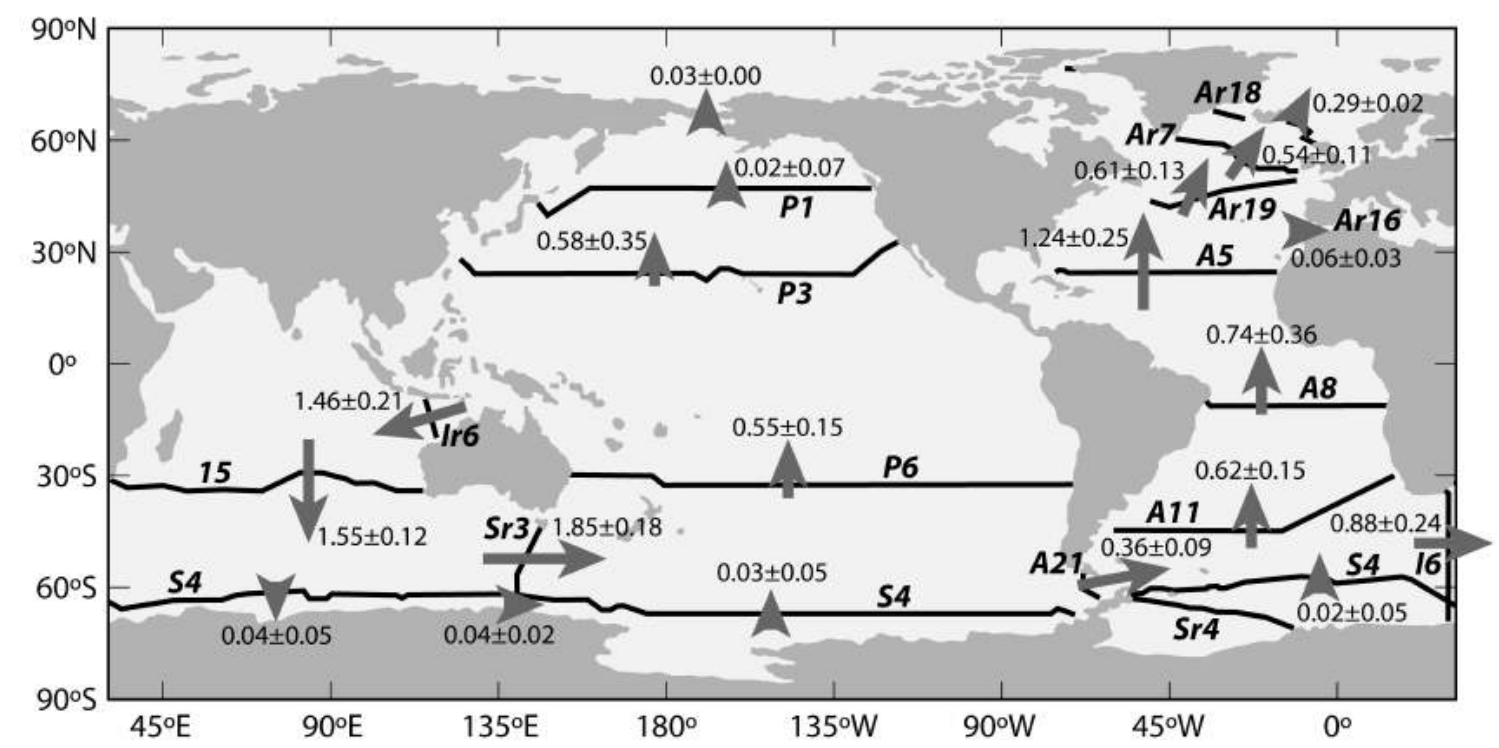

Figure 2.1: Global meridional heat flux estimates (in petawatts) showing the strongest heat transport in the south Indian Ocean. From Lumpkin and Speer (2007), Copyright American Meteorological Society. Used with permission.

Although the Indian Ocean occupies only $12 \%$, areally, of global ocean, it has accounted for more than one quarter of global ocean heat gain over the last twenty years (Cheng et al. 2017). Warming is basin-wide (Han et al., 2014), but is largest in the southerly reaches of the basin, within the Agulhas system (Wu et al., 2012) and along the subtropical front (Alory et al., 2007). In the tropics, this rapid warming, and a related increase in stratification, has led to reduced nutrient levels and a decline in primary productivity (Roxy et al. 2016). Accelerated warming has been attributed to a multidecadal increase in the Trade winds and resultant shoaling and strengthening of the Indonesian Throughflow (Sprintall et al., 2014; Lee et al., 2015) and also to a strengthening trend in the Westerlies and concomitant spin-up of the Southern Hemisphere super-gyre, although the Agulhas Current does not seem to have strengthened (Cai et al., 2007; Beal \& Elipot, 2016; Yang et al., 2016). At the same time, the export of heat from the Indian Ocean may have doubled, coinciding with a shift in the shallow overturning transport to lower densities (Hernández-Guerra \& Talley, 2016). 
In the long term, simulations suggest that the Indonesian Throughflow is expected to weaken with climate change from a reduction of bottom water inflow to the Pacific (Sen Gupta et al., 2016), and Agulhas leakage is expected to strengthen (Biastoch \& Böning, 2013) due to continued strengthening of the Westerlies. The influence of these anthropogenic changes on the nutrient and heat budgets is unclear. The Indonesian Throughflow is an important source of nutrients to the Indian Ocean, and its long-term decline may influence primary productivity in the eastern Indian Ocean upwelling regions (Ayers et al., 2014).

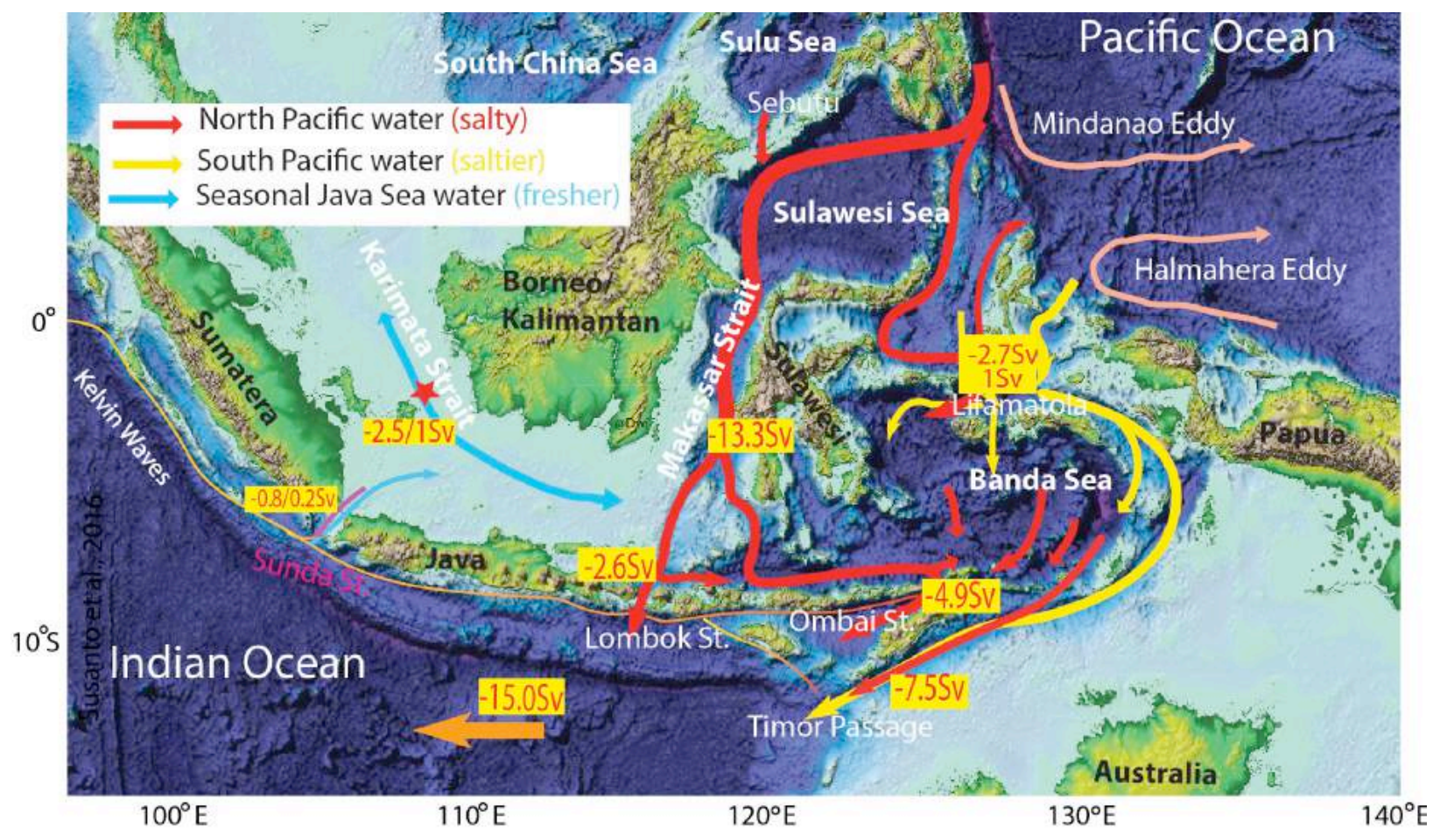

Figure 2.2: Indonesian throughflow pathways and mean transport. The number represents annual mean transports in Sv $\left(1 \mathrm{~Sv}=1 \times 10^{\wedge} 6 \mathrm{~m}^{\wedge} 3 / \mathrm{s}\right)$, except for the Sunda and Karimata Straits, which represent the seasonal mean transports. Negative values denote transport toward the Indian Ocean. Adapted from Figure 1 in Susanto et al. (2016). Used with permission from the Oceanography Society.

There exist a handful of estimates of the basin-wide Indian Ocean heat budget, largely based on three hydrographic surveys $(1987,2002,2009)$ along the open southern boundary of the basin $\left(\sim 32^{\circ} \mathrm{S}\right)$ combined with contemporary estimates of the Agulhas Current and a time-mean Indonesian Throughflow (e.g., Robbins \& Toole, 1997; Lumpkin \& Speer, 2007; McDonagh et al., 2008; Hernández-Guerra \& Talley, 2016). Estimates vary widely. Averaging them all for a mean and standard deviation, the Indian Ocean gains heat from the atmosphere at a rate of $0.47 \pm 0.328 \mathrm{PW}$ and the southward export of heat is $1.2 \pm 0.47 \mathrm{PW}$. The partitioning of the heat flux between the shallow (gyre) and deep overturning cells is unclear, with some estimates suggesting an equal contribution and others suggesting dominance of the shallow overturning cell. The Agulhas Current has a mean strength of $70 \mathrm{~Sv}$ at $32^{\circ} \mathrm{S}$ and $84 \mathrm{~Sv}$ at $34^{\circ} \mathrm{S}$ (Bryden et al., 2005; Beal et al., 2015) and its variability is thought to have the strongest influence on heat export from the Indian Ocean. Agulhas rings, which represent about $\sim 50 \%$ of 
Agulhas leakage (e.g., Loveday et al., 2015), have been estimated to carry $0.07 \mathrm{PW}$ of heat into the Atlantic (Souza et al., 2011). The Indonesian Throughflow is characterized by rigorous vertical mixing which produces characteristically low stratification (e.g., Nagai and Hibiya, 2015), with an average transport of $15 \mathrm{~Sv}$ at $17.6^{\circ} \mathrm{C}$ (Vranes et al., 2002; Sprintall et al., 2014) and a nutrient flux of about $1.5 \times 10^{11} \mu \mathrm{mol} \mathrm{N} \mathrm{s}{ }^{-1}$ (Ayers et al., 2014).
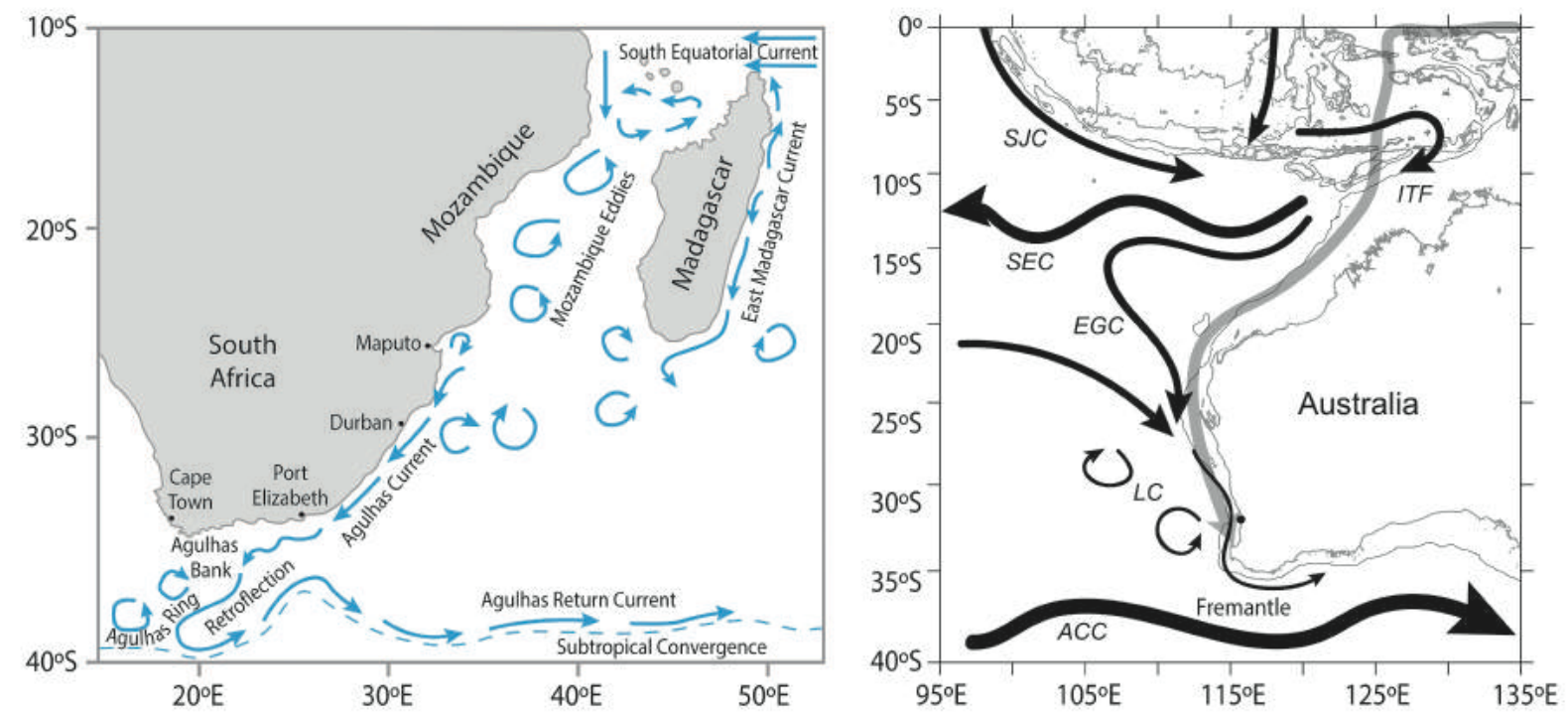

Figure 2.3: Left panel: Source waters, eddies and coastal flow of the Agulhas Current (from Lutjeharms and Bornman, 2010; Creative Commons Attribution 2.5 South Africa). Right panel: Leeuwin Current (from Feng et al., 2003; used with permission from John Wiley \& Sons, Inc.)

Interannual variability of the Agulhas Current and Indonesian Throughflow (and for the latter, its nutrient flux) is about $10-20 \%$ of their mean strengths and each can be attributed, in part, to the El Niño Southern Oscillation (Sprintall \& Révelard, 2014; Susanto \& Song, 2015). Variability of the basin-wide heat and nutrient budgets and their dependence on Agulhas and Indonesian exchanges, and on the shallow overturning cell, is unknown at any time scale.

\section{Scientific Motivation}

While continuous observations of the tropical Indian Ocean, led by RAMA, have undergone a step change over the last ten years, observations of the subtropical Indian Ocean are comparatively slim, aside from the Argo program, and this is where US IIOE2 can contribute. Our hypothesis is that while zonal patterns of upper ocean heat content dominate interannual climate variability over the tropical Indian Ocean, more meridional modes, related to exchanges of heat by the subtropical gyre and its shallow overturning at the open boundaries of the basin, will be important for climate over the Indian Ocean at decadal and multidecadal time scales (Lee et al., 2015; Yang et al., 2016). This hypothesis is, in part, analabous with decadal climate modes in the Pacific Ocean (e.g., Zhao \& Di Lorenzo, in rev.). Therefore, the variability of the Indian Ocean heat and nutrient budgets, and the relation of these budgets to interocean exchanges associated with the Indonesian Throughflow and the Agulhas Current, as well as to the 
export of southeast Indian mode water, are important to observe and understand so that we can reduce uncertainty in our predictions of future climate variability and change and their impacts on, for instance, marine ecosystems and extreme weather.

\section{Societal Relevance}

The increasing heat content of the Indian Ocean has already led to more extreme weather events, such as the intensification of cyclones (Webster et al., 2005), and to higher sea levels, increasing coastal inundation and erosion for many vulnerable Indian Ocean rim countries and island states. Sea level rise has accelerated along the coasts of India and Australia since the late 1990s and greater than global increases have been estimated along the coasts of Indonesia, Sumatra, Oman, and Madagascar (Han et al., 2010; Watson, 2011). These physical changes in the Indian Ocean will have multifaceted effects on marine organisms and ecosystems (Brierley and Kingsford, 2009). For instance, a $20 \%$ reduction in primary productivity of the western tropical Indian Ocean (Roxy et al., 2016) is putting additional stress on marine ecosystems in a region where oxygen depletion, acidification, and over-fishing has already led to decline (Obura et al., 2017). Funk et al. (2008) predict a 50\% increase in undernourished populations of East Africa owing to long-term decreases in rainfall due to the warming trends over the Indian Ocean. Improving our basic understanding of the basin-wide Indian Ocean heat budget will provide an underpinning for better understanding of its decadal variability and change, and for improved predictions that vulnerable populations can use for the long-term management of their fisheries and coasts.

\section{Scientific Questions}

How does the Indian Ocean heat budget vary over timescales from seasonal to decadal? Based on pioneering measurements of basin-wide heat flux in the North Atlantic (e.g., Johns et al., 2011), it is likely that seasonal changes in Indian Ocean fluxes compare to the uncertainty of the mean from all previous estimates over the last thirty years, such that decadal changes are currently undetectable. Quantifying the variability is the first step towards a basic understanding of the main drivers of the heat budget and towards separating natural and anthropogenic change.

What is the role of the subtropical gyre transport, of meridional overturning associated with mode water formation, and of the Indonesian Throughflow and the Agulhas system in basin-wide heat and nutrient budgets and their changes? These exchanges are thought to dominate Indian Ocean heat content (e.g., Bryden \& Beal, 2001; Han et al., 2014; Lee et al., 2015), but what are the relevant time scales and how does their influence compare to other mechanisms, such as Ekman pumping, heat storage, and eddies? Why is the Indian Ocean warming so fast and when and how will it export that heat? What is the nutrient flux of the Agulhas Current? Can a reduction in the influx of nutrients from the Indonesian Seas adversely impact productivity and/or change microbial food web dynamics of the important fisheries along the eastern boundary?

How are the Indian Ocean heat and nutrient budgets linked to decadal variability of sea surface temperature, sea level, and primary productivity? Unlike in the 
Pacific, patterns of sea surface temperature change are rather uniform across the Indian Ocean, pointing to a potential connection to the basin-scale heat budget (Han et al., 2010; 2014). How closely can we relate surface signals to heat flux variability and to the major exchanges via the shallow meridional overturning cell, Indonesian Throughflow and Agulhas Current? What are the drivers of the decline in primary productivity across the South Indian Ocean (Jena et al., 2013)? How is this decline impacting the marine food web?

\section{Implementation}

Several coordinated elements are necessary to quantify the basin-wide Indian Ocean heat budget: An Indonesian Throughflow observing system, an Agulhas Current observing system, and an observing system along the open southern boundary of the Indian Ocean at mid-latitudes.

For the Indonesian Throughflow there are on-going programs that are currently observing some of the eastern passages of the Indonesian Seas (Indonesia-China, ten moorings; Indonesia-USA-China, two moorings). However, large gaps exist in observations of the outflow. US funding for the Makassar Strait mooring, which has been occupied almost continuously since 2004, comes to an end in 2018 and Australian moorings in Ombai and Timor Passages were recovered in 2015 after deterioration of diplomatic relations with Timor-Leste. Simultaneous moored measurements of velocity and property (temperature, salinity, nutrients) variability in the outflow passages of Lombok, Sape, Ombai and Timor are needed to quantify the Indonesian Throughflow. Measurements in the Timor Passage would leverage existing moorings to the south on the NW Australian shelf. A 35-year, high-density XBT (Expendable Bathythermograph, temperature-depth) line between Australia and Indonesia provides interannual variability of geostrophic Throughflow transport (Liu et al., 2015), yet for decadal time-scales variations in salinity properties need to be taken into account. Observations of nutrient flux are also important because the vertically-mixed Throughflow waters are high in nutrients (Ayers et al., 2014) and are delivered directly into some of the strongest upwelling regions of the Indian Ocean. Efforts would coordinate with two process experiments already underway in the region, the Eastern Indian Ocean Upwelling Research Initiative and the Years of the Maritime Continent.

For the Agulhas Current a pilot mooring array, consisting of seven full-depth moorings and four CPIES, was in place from 2016 to 2018 (South Africa-US-Netherlands, Agulhas System Climate Array) to measure velocity, temperature, and salinity variability. Efforts are needed to redeploy and sustain this array and augment it for measurements of nutrients. A South African glider program provided some complementary measurements of the highly sheared shoreward side of the western boundary jet.

For the open southern boundary of the Indian Ocean, hydrographic end-point moorings positioned in deep water off South Africa and Australia are needed to measure the basin-wide geostrophic transport (McCarthy et al., 2015). The Agulhas array currently provides an end-point mooring in the west. A hydrographic mooring of at least $2000 \mathrm{~m}$ depth should be added to the Australian Leeuwin Current array (Feng et al., 2011) to 
provide the eastern end-point (Fig. 2.3). In the Indian Ocean the deep overturning cellAntarctic Bottom Water to Indian Deep Water-is clearly separated from the intermediate and shallow cells above $2000 \mathrm{~m}$, which are thought to carry most of the heat transport (Talley, 2003; Ferrari and Ferreira, 2011). To capture nutrient transports and the gyre component of the heat transport (Johns et al., 2011) BGC Argo floats should be seeded in the Indian Ocean subtropical gyre. These new measurements will leverage the existing global Argo and surface drifter programs and the GO-SHIP hydrographic section 15, which collects a full suite of biogeochemical properties, including silicates which are a useful constraint on the deep overturning cell (Robbins \& Toole, 1997).

These proposed new observations should be complemented by satellite data (sea surface height, temperature, and ocean color) and numerical models to address the scientific questions above.

\section{Theme 3: Monsoon Dynamics}

\section{Introduction}

The monsoon is the dominant mode of natural variability of the ocean and atmosphere in northern and equatorial regions of the Indian Ocean and over its rim countries (Fig. 3.1). Intra-seasonal monsoon variability is driven by eastward propagation of the Madden-Julian Oscillation during boreal fall and winter (Madden and Julian, 1972, Fig. 3.2), which exhibits northward propagation as well during boreal spring and summer as the Monsoon Intraseasonal Oscillation (MISO, Lawrence and Webster, 2002). There are also 3-7 day oscillations of the monsoon trough (Gadgil, 2003), and 10-20 day oscillations associated with westward moving synoptic-scale disturbances (Chatterjee and Goswami, 2004) and convectively coupled Kelvin and Rossby waves (Wheeler and Kiladis, 1999).

The monsoon remains a grand challenge for forecasts on subseasonal-to-seasonal (S2S) and longer timescales. CMIP5 models fail to capture the observed weakening trend in the Indian summer monsoon (Saha et al. 2014; Sabeerali et al., 2015; Yang et al., 2015), likely due to missing aerosol impacts on land warming or biases in Indian Ocean sea surface temperature. Future projections of the East African and Indian summer monsoon are also unreliable, because of dynamic inconsistencies between models. In the meantime, food, water and energy security of the rim countries are largely dependent on the vagaries of the regional monsoons. The African-AsianAustralian monsoons are an inherently multi-scale system with air-sea interactions spanning from diurnal to decadal and longer timescales, which must be understood through integrated approaches of in situ observations, data analysis, and numerical modeling. All six IIOE-2 scientific themes in the international science plan (Hood et al., 2015) are intimately tied to monsoon dynamics and can be adequately investigated only with advanced understanding of monsoon dynamics and improved monsoon prediction and simulations. 

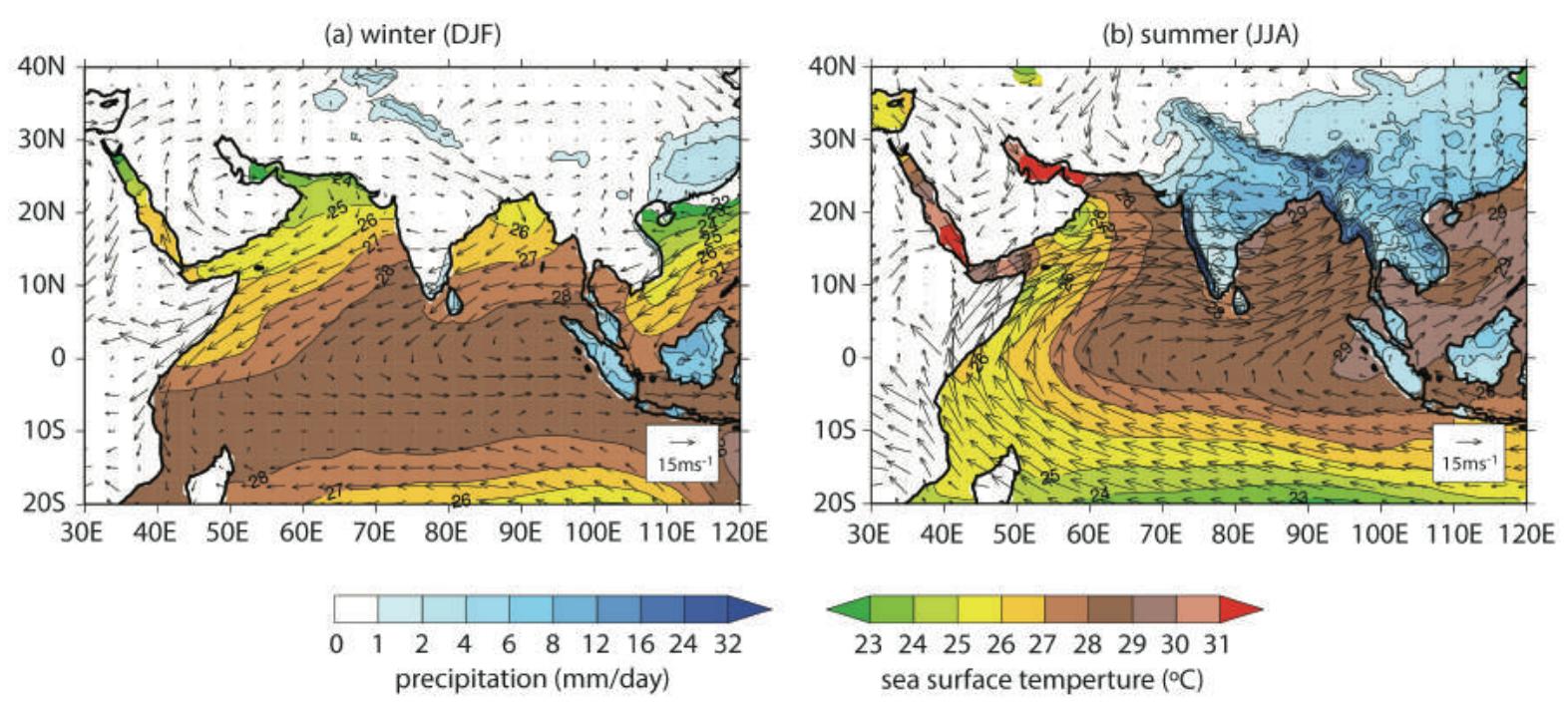

Figure 3.1: Schematic diagram of boreal winter (December-February; left) and summer (JuneAugust; right) daily mean precipitation, sea surface temperature (SST) and winds over the Indian Ocean and adjacent continents (provided by Andrew Turner, Univ. of Reading, UK).

The Indian Ocean is an integral component of tropical-coupled climate variability (Fig. 3.3) with regionally unique characteristics in the Arabian Sea, Bay of Bengal, eastern and western equatorial zones, and the southern tropical and subtropical oceans. In addition to the predominant atmospheric bridges from the Pacific (Lee and McPhaden, 2008) and Atlantic oceans (Zhang and Delworth, 2006) that impact the oceanatmosphere and monsoon dynamics, remote forcing at seasonal-to-interannual and longer timescales are injected into the India Ocean via oceanic pathways such as the Indonesian Throughflow (Fig. 2.2; Zhou et al., 2008a,b; Sprintall and Revelard, 2014). The Indian Ocean is sequestering much of the heat transported via the ITF and played a role in the so-called Global Warming Hiatus (Lee et al., 2015). The greatest challenge as far as the air-sea interactions and the monsoon dynamics are concerned will be to understand this multi-scale system, where high mean SSTs over much of the domain cause even small variations to have disproportionately large impacts on air-sea interactions. The integration of local and remote forcing by this warm ocean at diurnalto-decadal and longer time-scales must be understood within the context of its regional contrasts in natural variability and secular trends and their multi-scale impacts on local air-sea interactions and monsoon dynamics.

\section{Scientific Motivation}

Monsoon dynamics and the Indian Ocean have been the subject of intense research for well over a century, and were a major driver of the original IIOE. Rapid warming of the Indian Ocean (Alory et al., 2007), together with unsolved mysteries of the monsoon as well as new processes and predictive understanding advanced by growing capabilities of monitoring, simulating and predicting the monsoon have maintained the spotlight on this warm ocean. Among others, two challenging scientific issues need to be addressed with urgency: 1) The contrasting physical processes in four dynamically distinct regions of the Indian Ocean need to be better characterized, namely the Arabian Sea (AS), Bay 
of Bengal (BoB), southwestern tropical Indian Ocean (SWTIO) or Seychelles-Chagos Thermocline Ridge (SCTR), and the eastern tropical Indian Ocean (ETIO), and 2) the dynamics of the shallow overturning and of the Agulhas Current and ITF that connect the monsoon-dominant Indian Ocean to adjacent oceans need to be better understood.

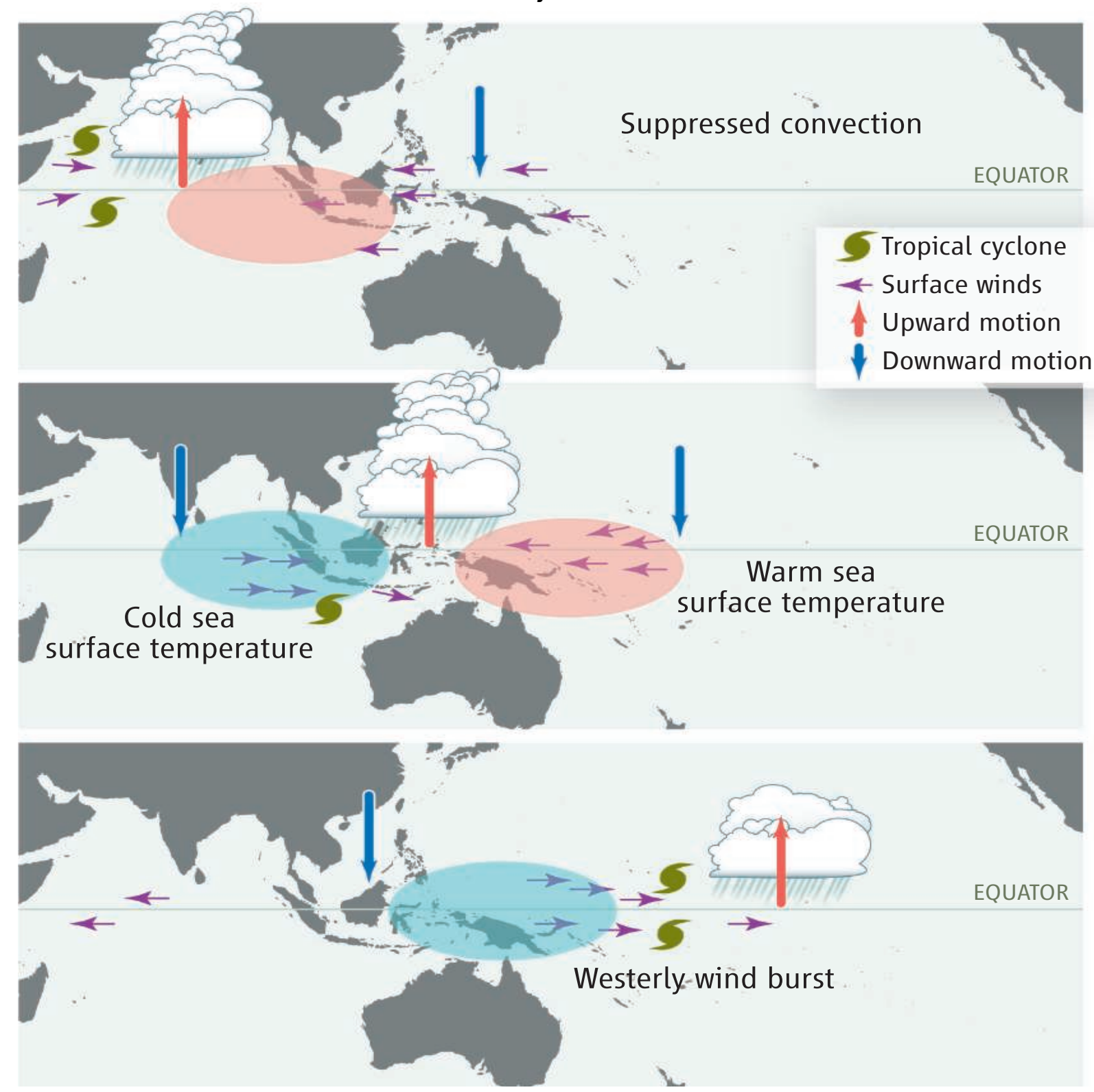

Figure 3.2: Illustration of the Madden-Julian Oscillation. Precipitation first develops in the Indian Ocean and moves eastward with a speed of about $5 \mathrm{~m} \mathrm{~s}^{-1}$. From Hartmann and Hendon 2007. Reprinted with permission from AAAS.

Each of the above four regions (AS, BoB, SCTR, ETIO) is distinct in its warming trends and potential impacts of the warming on local air-sea interactions, biogeochemistry and ecosystems, as well as on the non-local forcing of the regional monsoons at S2S timescales. Natural modes of lower-frequency variability of the Indian Ocean are being modulated via the ITF by Pacific Ocean forcing that includes the Walker and Hadley cell responses and the warming patterns that could be El Niño-like or La Niña-like. The unique geometry of the Southern Ocean allows the warming to penetrate deeper more 
rapidly, which, in turn, is communicated to the tropical Indian Ocean on multi-decadal timescales. The impact of the shallow overturning cell, Agulhas Current, ITF and the meridional overturning circulation (MOC) on the Indian Ocean remains a challenge as far as deciphering their integrated effects on the low-frequency monsoon dynamics in a warming climate.

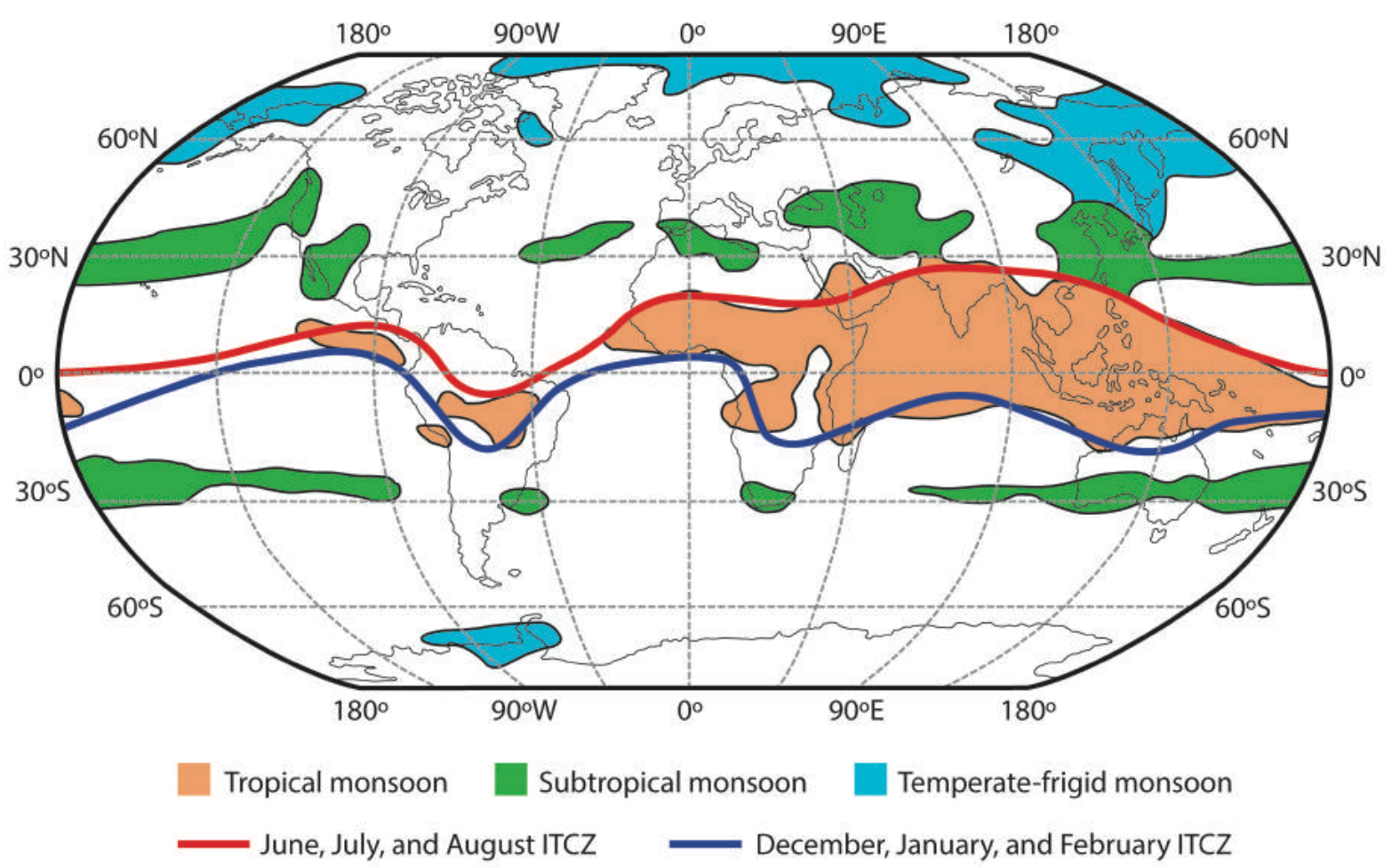

Figure 3.3: The global monsoon distribution, where the Indian Ocean and its rim are under the regime of African-Asian-Australian monsoon (from Li and Zeng, 2003). Reprinted by permission from Springer, Nature, Advances in Atmospheric Sciences, Copyright (2003).

\section{Societal Relevance}

Advanced understanding of monsoon dynamics is the foundation of improved predictions and reliable projections of the monsoons for the Indian Ocean rim countries, which host $25 \%$ of the world's population and remain some of the most vulnerable regions to climate change impacts. With the rapid warming that is expected to continue, the impact on fisheries and marine ecosystems, as well as the source/sink variability of the anthropogenic $\mathrm{CO}_{2}$, are critical scientific challenges. Increasing population density underscores the need to understand and monitor Indian Ocean warming and its feedback to monsoon dynamics and society. Considering that every aspect of the monsoon, including onset, breaks, withdrawal, mean rainfall and extremes, are likely to be altered by global warming (Goswami et al., 2006; Turner and Annamalai, 2012), it is paramount to re-emphasize the dependence of the vast agricultural enterprise on S2S timescales and thus the need for major advancement on process and predictive understanding at these timescales. Monsoon variability on S2S timescales is a potential source of predictability for forecasts beyond two weeks that would lead to 
greater application of science for societal benefit. Accurately representing the role of airsea interaction in MJO initiation over the Indian Ocean is crucial to forecasting its global impacts (Zhang, 2013).

\section{Scientific Questions}

The U.S. IIOE-2 research strategy on monsoon dynamics should focus on the following fundamental questions to advance the integrated observations, modeling, understanding, predictions and projections of the complex multi-scale monsoon system.

Coordinated studies need to be undertaken to examine the contrasts between the four regions identified above (AS, BoB, SCTR, ETIO). What are the regional specificities of the ocean dynamics and air-sea interactions and their dependence on the background states in each region? How do the region-specific multi-scale ocean dynamics and air-sea interactions influence variability and predictability on S2S timescales? What are the root causes of biases and errors in the four regions in the state-of-the-art climate and Earth system models? How is each region responding to anthropogenic forcing and how is each region affecting other region's response and the overall monsoon dynamics at S2S timescales?

In addition, studies need to be undertaken to improve current understanding of the dynamics of the Southern Ocean, MOC, shallow overturning cell, and ITF, and their integrated impacts on the monsoon on decadal and longer timescales. What are the dominant low-frequency natural variability patterns and timescales in the Indian Ocean? How are the low-frequency variabilities in the Indian Ocean affected by the response in the Southern and Pacific oceans to global warming? Is there a natural flushing timescale for the Indian Ocean (i.e., the timescale at which deep and intermediate waters of the incoming MOC are converted to surface water and transported out of the Indian Ocean) and its four regions identified above, and are they being modulated by trends in MOC, shallow overturning cell, and ITF? How are the Southern and Pacific ocean responses translated into the MOC, shallow overturning cell, and ITF variability, and how are MOC, shallow overturning cell, and ITF variability in the Indian Ocean integrating into Indian Ocean warming and sea level change? How would these low-frequency modes and their responses to climate change affect the monsoon?

\section{Implementation}

While each subregion has been a focus of process studies and each can offer a unique return on investment, a focused process study in the SCTR may offer the best opportunity for advancing process and predictive understanding for the monsoon dynamics at S2S timescales (see also Theme 1). The SCTR plays a role in determining the sub-seasonal genesis of MJOs, it plays a role in controlling MISO and monsoon onset, and subseasonal-to-seasonal moisture fluxes (Pathak et al., 2017a,b), and it also plays a role in integrating the local dynamics as well as shallow overturning and ITF forcing on the local background state. New data can be collected from field campaigns, autonomous instruments, and sustained and enhanced IndOOS observations (Fig. 3.4) for detailed processes of upper-ocean mixing, air-sea interactions, and atmospheric 
convection related to the MJO and inter-tropical convergence zone (ITCZ) in this unique tropical mixing bowl.

Indian Ocean Integrated Observing System

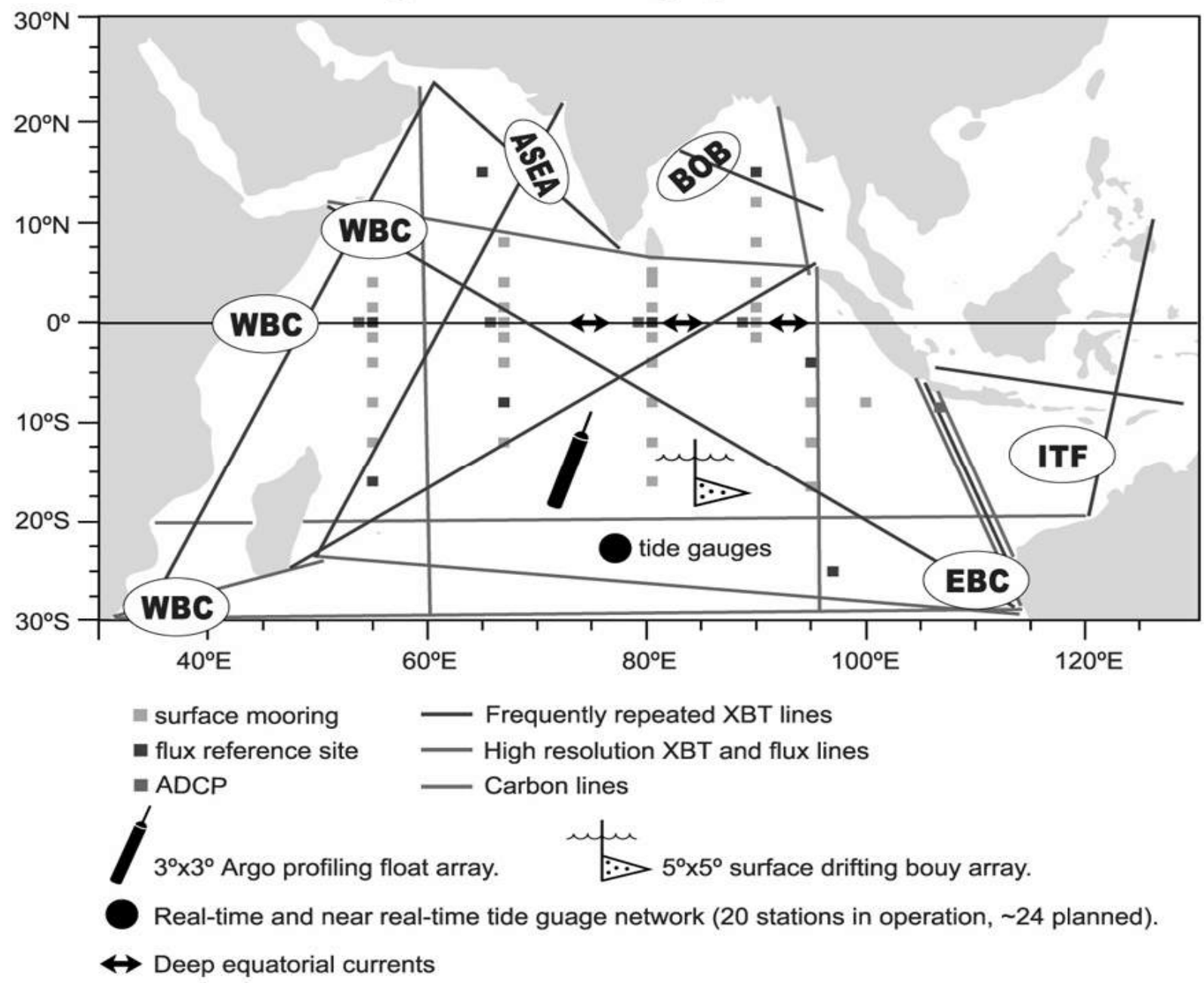

Figure 3.4: An Integrated Observing System for the Indian Ocean.

Existing observations and global data should be synthesized to provide a coherent picture of natural variability at S2S and longer timescales as well as the unique sea level rise signature as an integral of the trends in ITF, shallow overturning and the Walker circulation. Numerical experiments can be designed to understand the S2S variability, including the potential feedbacks from the MJO-driven waves that interact with the ITF and feed back to the SCTR that may, in turn, influence the subsequent MJO initiation in this uniquely multi-scale interaction region (Zhou and Murtugudde, 2009). Studies in this region can also shed light on the model biases in predictions and projections by understanding the SCTR's contribution to the moisture flux to the monsoons and the competition for ocean versus land rainfall and the marine versus continental ITCZ.

Efforts to improve understanding of the dynamics of the Southern Ocean, MOC, and ITF will depend critically on maintaining the zonal lines of RAMA moorings (Fig. 3.4). Additional Observing System Simulation Experiments (OSSE) should be undertaken to 
determine the ideal mooring locations that are needed to help close heat and mass transport budgets at S2S and longer timescales and monitor the Indian Ocean's response to MOC and ITF trends.

Data from several other previous and existing activities can be leveraged to support research related to this theme (e.g., NASCar, MISO-BOB (Oceanic Control of Monsoon Intra-seasonal Oscillations in the Tropical Indian Ocean and the Bay of Bengal), EIOURI (Eastern Indian Ocean Upwelling Research Initiative), IndOOS, and scheduled and planned Indian/Chinese IIOE-2 cruises). There is also a DeepSea proposal planned for submission to the Indian Ministry of Environmental Sciences to establish a GO-SHIPlike line at $6^{\circ} \mathrm{N}$. This line could provide additional valuable atmospheric, oceanic and air-sea exchange data to support research related to monsoon dynamics. Careful diagnostic analysis of CMIP5/6 (Coupled Model Intercomparison Project Phase 5 and 6) simulations could also provide useful information.

\section{Theme 4: Physical, Biogeochemical and Ecological Contrasts Between the Arabian Sea and the Bay of Bengal}

\section{Introduction}

The Arabian Sea and the Bay of Bengal are similar in size, latitude and proximity to the northern land boundary, and both are strongly influenced by monsoonal winds. However, these systems exhibit very different physical, biogeochemical, and ecological characteristics. The most striking differences between the Arabian Sea and the Bay of Bengal stem from their responses to the semi-annually reversing monsoonal winds -the subject of Theme 3. The Southwest Monsoon (SWM) winds over the Arabian Sea are stronger, forming the intense Findlater Jet (Findlater, 1969) that drives strong seasonal upwelling along the coasts of Somalia, Yemen and Oman, as revealed by high chlorophyll concentrations (Fig. 4.1, bottom right) and cool surface temperatures. While the boundary currents in both basins reverse seasonally (Fig. 4.1, middle panels), the chlorophyll-rich filaments, jets and eddies that extend hundreds of kilometers offshore in the western Arabian Sea have no analog in the Bay of Bengal (Fig. 4.1, bottom right). One reason for this difference is that the upwelling-favorable winds that occur along the east coast of India during the SWM (Fig. 4.1, upper right) are much weaker. The surface ocean is also much more stratified in the Bay of Bengal than in the Arabian Sea due to massive freshwater input (see below), which masks coastal upwelling.

Much higher levels of surface kinetic energy result from monsoonal forcing in the Arabian Sea compared to the Bay of Bengal, as evidenced by the strength of the seasonally reversing Somali Current relative to the East Indian Coastal Current. The African coast is an uninterrupted western boundary that permits the cross-equatorial flow of the East African Coastal Current to contribute to the much larger transport of the Somali Current. A similarly sharp contrast in monsoonal forcing occurs during the Northeast Monsoon (NEM), when the air mass interacting with the Arabian Sea originates from the Tibetan Plateau. The combination of this colder, dryer air with a less stratified upper ocean leads to deeper convective mixing in the Arabian Sea than in the 
Bay of Bengal. The net result is that the physical, biological and ecological responses to monsoonal forcing are generally stronger in the Arabian Sea than in the Bay of Bengal.
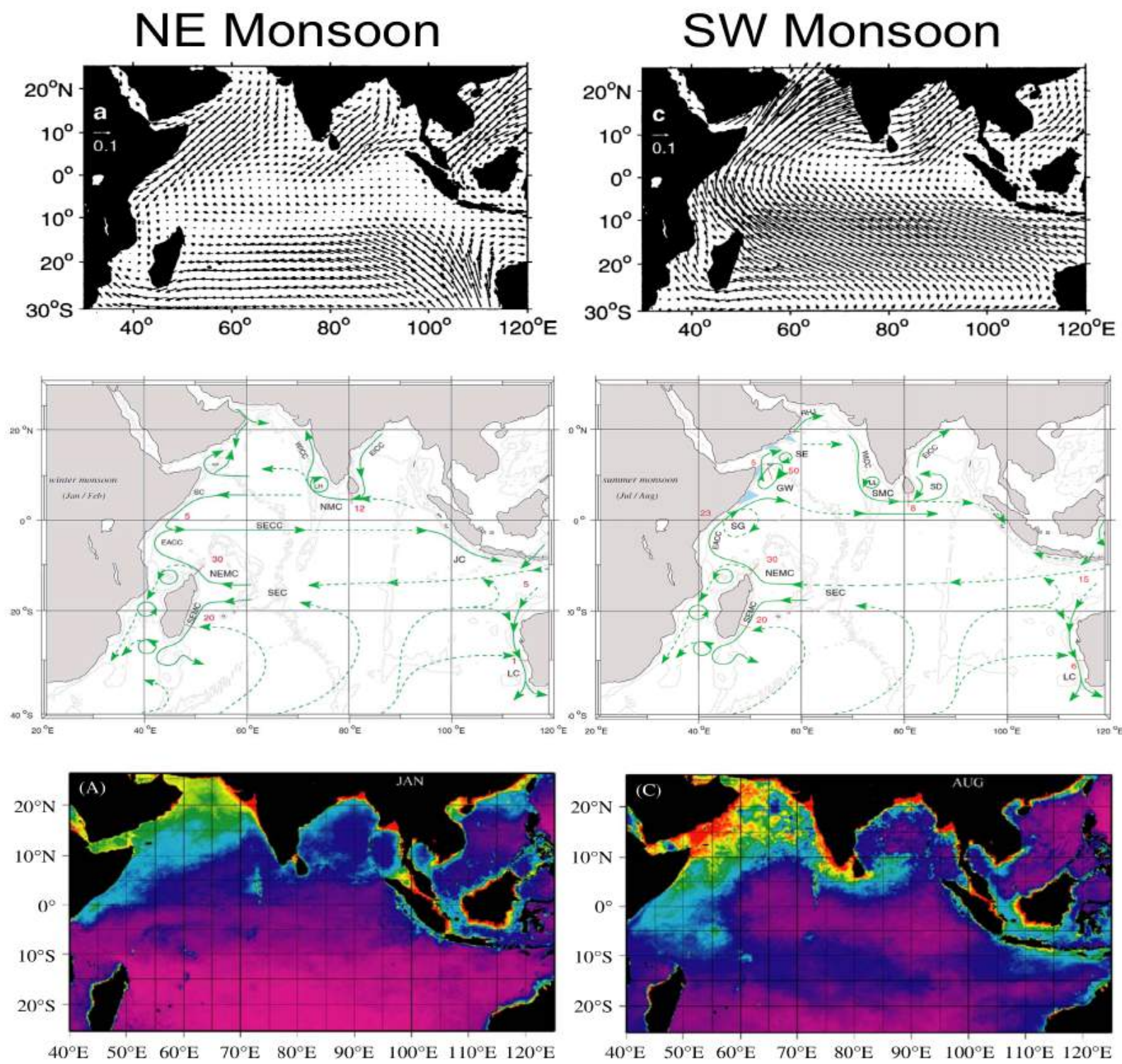

Chl $a\left(\mathbf{m g} / \mathbf{m}^{3}\right)$

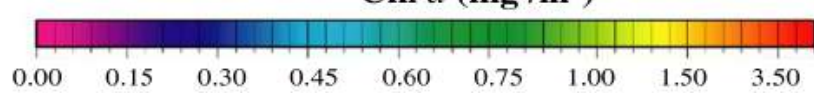

Figure 4.1: Comparison of (upper) winds, (middle) surface ocean circulation, and (bottom) satellite-derived chlorophyll concentration between the (left column) January-February and (right column) July-August periods in the Indian Ocean. The wind and circulation fields are from Schott and McCreary (2001), Copyright (2001). Reproduced with permission from Elsevier. The satellite chlorophyll concentrations are reproduced from Wiggert et al. (2006), Copyright (2006). Reproduced with permission from Elsevier.

As described above, the surface stratification in the two basins differs, with the open ocean surface waters of the Arabian Sea among the world's most saline and the open ocean surface waters of the Bay of the Bengal among the freshest. This salinity contrast reflects differences in both freshwater input from rivers and net evaporation (evaporation minus precipitation, or E-P) (Fig. 4.2). The northern Arabian Sea, including 
the adjacent Red Sea and Persian Gulf, experiences salinification due to evaporative buoyancy flux, whereas the Bay of Bengal is subject to significant freshening from monsoonal precipitation and runoff from major rivers such as the Ganges/Brahmaputra and the Irrawaddy. In the Bay of Bengal, a buoyant low-salinity surface layer greatly inhibits vertical mixing, thus limiting mid-water ventilation and surface expression of weak, wind-driven upwelling along the east coast of India (Kumar et al., 1996). Surface cooling and the net excess of evaporation over combined precipitation and runoff lead to weaker stratification during both the SWM and NEM in the Arabian Sea. The northcentral Arabian Sea is unusual because of semi-annual deepening of the surface mixed layer, resulting from convection and wind stirring in winter (NEM), and extremely strong wind stirring in summer (SWM). Together these forcing regimes lead to the region's unique semi-annual peak in primary production (Lévy et al., 2007).

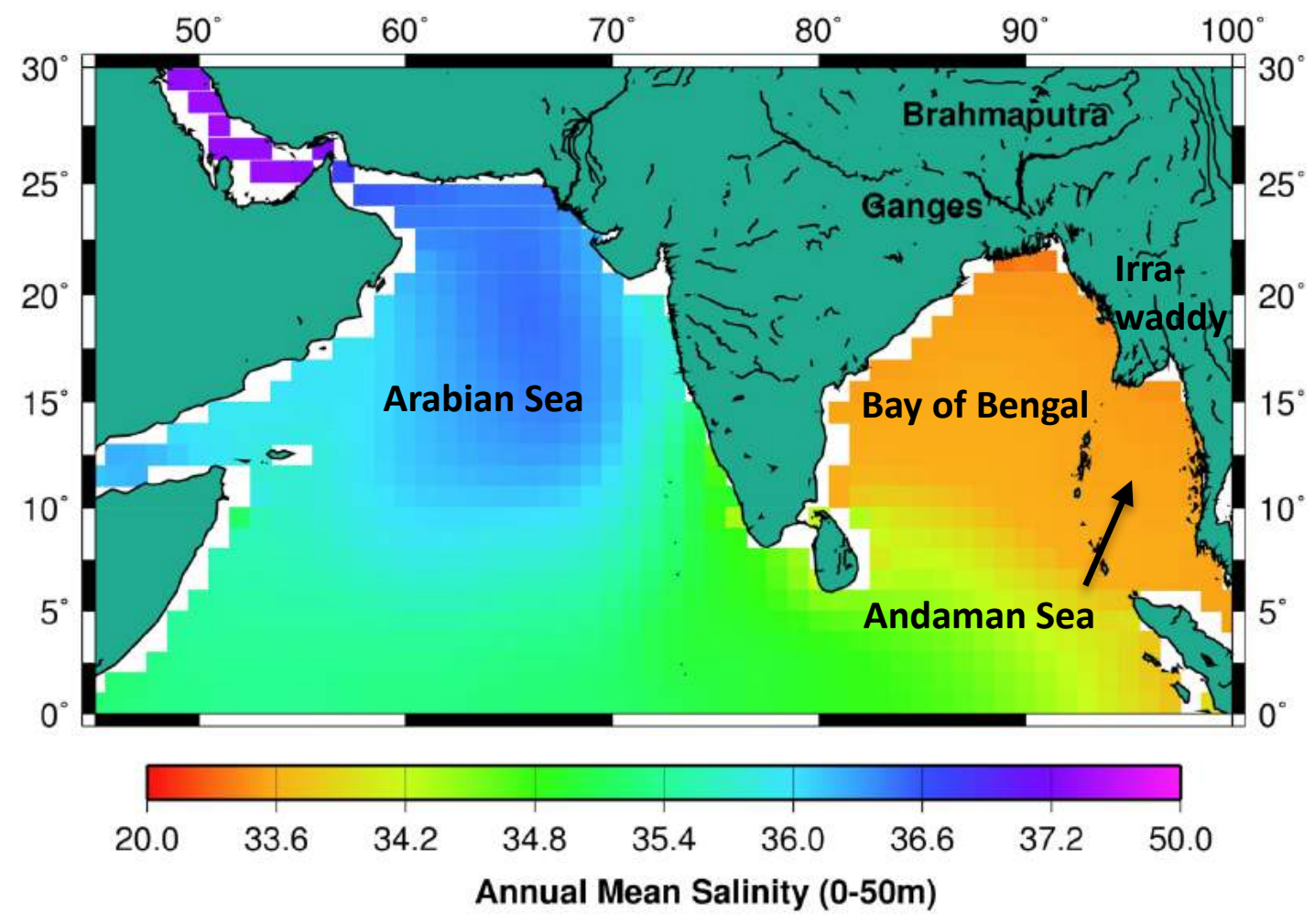

Figure 4.2: Annual mean salinity in the surface waters of the northern Indian Ocean. Data were obtained from the World Ocean Atlas 2001 (Conkright et al., 2002).

Small but critical differences in subsurface oxygen concentrations between the Arabian Sea and the Bay of Bengal (Fig. 4.3) are poorly characterized and understood. Conceptually, for example, higher stratification should lead to a larger oxygen minimum zone in the Bay of Bengal than in the Arabian Sea, in contrast to what is observed. Oxygen is almost completely depleted between about 150 and $600 \mathrm{~m}$ depth in the eastern central Arabian Sea. Respiration of sinking particles derived from coastal upwelling, coupled with slow subsurface water mass ventilation, combine to form this low-oxygen zone, setting the stage for denitrification, where bacteria begin to utilize nitrate as the terminal electron acceptor for respiration, converting it to $\mathrm{N}_{2} \mathrm{O}$ and $\mathrm{N}_{2}$ gas that is then released to the atmosphere (Naqvi, 1987; Codispoti et al., 2001; Ward et al., 
2009). The Arabian Sea OMZ contributes $\sim 20 \%$ to global water-column denitrification (Bange et al., 2000; Codispoti et al., 2001), although there is now debate about the relative contributions of denitrification versus the chemosynthetic anammox (anaerobic ammonium oxidation) reaction to $\mathrm{N}_{2}$ gas production in the Arabian Sea (Ward et al., 2009). $\mathrm{N}_{2} \mathrm{O}$ is also a potent greenhouse gas. The Arabian Sea is estimated to contribute around one-fifth of the total $\mathrm{N}_{2} \mathrm{O}$ emission from the global ocean (Bange et al., 2001), but there are large uncertainties in these estimates as well. This low-oxygen water, which is formed as a result of respiration, is also associated with high $\mathrm{CO}_{2}$ concentrations and, consequently, low pH. In contrast, in the Bay of Bengal, where the mesopelagic dissolved oxygen concentrations are slightly higher, the system remains poised just above the denitrification threshold (Fig. 4.3). Total inorganic carbon and alkalinity are significantly lower in the Bay of Bengal surface layer than in the Arabian Sea due to freshwater dilution. The $\mathrm{pH}$ in the Bay of Bengal OMZ might also be higher, but studies of acidification are generally lacking in this area.

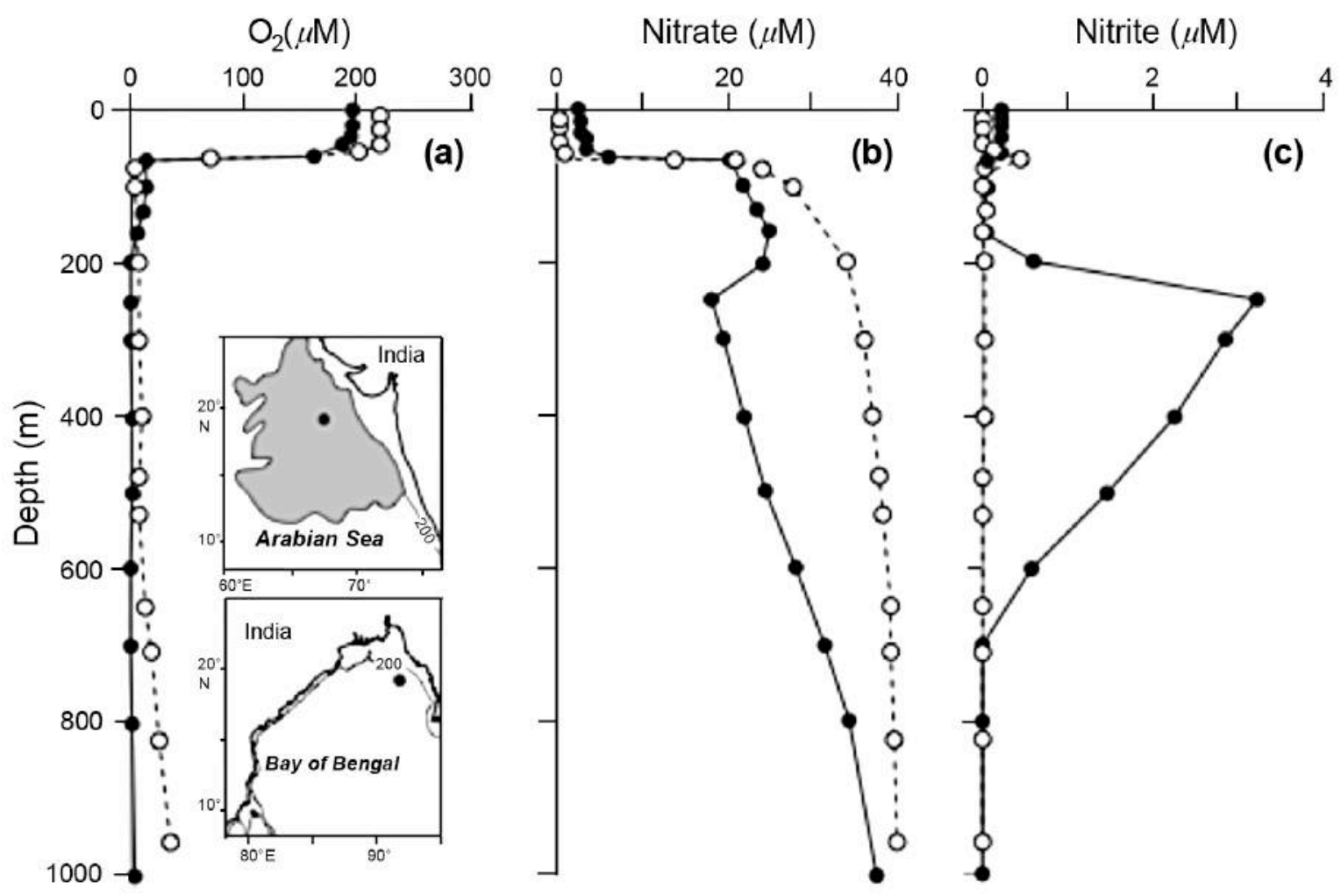

Figure 4.3: Comparison of vertical profiles of (a) oxygen, (b) nitrate and (c) nitrite in the AS (filled circles) and BoB (open circles). Station locations are shown in insets. The AS inset also shows limit of the denitrification zone to the eastern-central basin. Reproduced from Naqvi et al. (2006). Copyright 2006 by the President and Fellows of Harvard University, Harvard University Press.

In the Arabian Sea off the west coast of India, coastal upwelling leads to the incursion of corrosive oxygen-depleted waters onto the continental shelf (Naqvi et al., 2009), with negative consequences for commercially important fisheries. This occurs annually during late summer/autumn in the inner-shelf region north of about $12^{\circ} \mathrm{N}$. Retrospective analyses of subsurface waters suggest that oxygen concentrations are declining in the Indian Ocean, as they are in other ocean basins in response to climate change and global warming (Stramma et al., 2008). It can be expected that these trends, which are 
accompanied by increasing atmospheric and oceanic $\mathrm{CO}_{2}$ concentrations, will lead to the expansion of the OMZs in the northern Indian Ocean, with negative consequences for fisheries and coral reef ecosystems in both the Arabian Sea and the Bay of Bengal (Stramma et al., 2010).

\section{Scientific Motivation}

The striking physical, biogeochemical and ecological contrasts between the Arabian Sea and the Bay of Bengal are fundamentally related to the characteristics of the monsoon wind forcing and the amount of freshwater influx relative to E-P, which differ starkly between the two basins. The greater intensity of oxygen depletion in the Arabian Sea compared to the Bay of Bengal is directly related to this forcing, which gives rise to different balances in oxygen ventilation versus biological oxygen demand, yet these balances are not yet fully understood (McCreary et al., 2013). Moreover, it is very likely that the ventilation and biological oxygen demands are changing in response to global warming, which will potentially have even more profound biogeochemical and ecological consequences in the future (e.g., Goes et al., 2005; Gomes, et al., 2009; 2014; Stramma et al., 2010). To predict the response of these regions to anthropogenic change, three fundamental issues need to be understood: 1) the balances between oxygen ventilation and biological oxygen demand in the Arabian Sea and the Bay of Bengal need to be better quantified, and studies need to be undertaken to determine why they differ, how they have changed in the past, and how they are likely to change in the future; 2) the biogeochemical and ecological consequences of these different balances need to be examined, especially as they relate to the size and the intensity of the OMZs, rates of denitrification, and $\mathrm{N}_{2} \mathrm{O} / \mathrm{N}_{2}$ production, and efforts need to be motivated to determine how these are likely to change in the future; and 3) the potential negative biogeochemical and ecological impacts of the expanding OMZs need to be examined in the Arabian Sea and the Bay of Bengal in both open ocean and coastal environments.

\section{Societal Relevance}

The northern Indian Ocean is warming (Alory et al., 2007), oxygen concentrations are dropping (Stramma et al., 2008), and $\mathrm{CO}_{2}$ concentrations are rising (Takahashi et al., 2002), with associated declines in $\mathrm{pH}$ (Rashid and Akter, 2013). These environmental stressors are among the most important threats facing marine ecosystems today (Gruber, 2011; Halpern et al., 2012). It is already clear that these changes are giving rise to profound negative biogeochemical and ecological consequences, which include changes in both coastal (e.g., McClanahan et al., 2007; Naqvi et al., 2009; Moore et al., 2012) and open-ocean ecosystems (e.g., Gomes et al., 2009; Gomes et al., 2014). It is likely that these negative impacts will manifest even more strongly in the future. Studies of the physical and biogeochemical contrasts between the Arabian Sea and the Bay of Bengal will provide an improved understanding of the physical and biogeochemical dynamics of these two contrasting basins, which provide resources for a quarter of the world's population. This research will provide greater insight into how the multiple stressors of warming, deoxygenation and acidification are changing in the Indian Ocean and, in turn, how they could impact these two contrasting ecosystems and, ultimately, fisheries and human populations around the Indian Ocean rim. 


\section{Scientific Questions}

The northern Indian Ocean OMZs differ substantially from Pacific OMZs due to monsoon-driven flow reversals in the western boundary current, organic matter source regions, and strong variability in freshwater inputs from precipitation, terrigenous runoff, and rivers. It is likely that the balance between the ventilation timescale and local organic matter respiration differs substantially between the Pacific and Indian ocean OMZs. Riverine inputs are particularly important in the Bay of Bengal, where they provide large contributions of dissolved and particulate carbon, nitrogen, phosphorus and sediment. These considerations lead to the following overarching question: What controls the source variability, local ventilation, biological oxygen demand and biological and biogeochemical impact of the two northern Indian Ocean lowoxygen regions?

The northern Indian Ocean has only a very limited subtropical temperate zone because it is bounded to the north at subtropical latitudes by the Eurasian landmass. As a result, the northern Indian Ocean boundary currents do not flow into cooler, subpolar water masses. In contrast with the North Atlantic, the northern Indian Ocean has no source of dense, cold water. The dense water source in the Arabian Sea, which is primarily from the Red Sea (resulting from evaporation and winter cooling), is similar to the Mediterranean Sea's mid-latitude dense water source; both have limited overturning transports and principally impact the ocean through injection of high salinity at middepth. In contrast to the Arabian Sea, these high-salinity mid-depth sources are absent in the Bay of Bengal and are replaced by surface freshwater sources (both riverine and precipitation). How do these influences (lack of northern Indian Ocean dense cold water sources, dense saline sources in the Arabian Sea, and low-density freshwater sources in the Bay of Bengal) contribute to the observed differences in the physical structure, stratification, ventilation, biological oxygen demand, OMZ intensity and microbial food web structure between the Arabian Sea and the Bay of Bengal?

The northern Indian Ocean is subject to strong anthropogenic and climate influences that affect both the physics and the biogeochemistry of the region through modulation of anthropogenic aerosols and climate-induced variability in dust fluxes and surface heat exchange. Are the Northern Indian Ocean OMZs uniquely sensitive to climate change as a result of these strong anthropogenic and climate influences? If so, how will climate change impact the OMZs and, in particular, how will climate change impact the interactions between monsoon wind intensity and timing, increased anthropogenic nutrients and carbon inputs, low oxygen and acidification?

It remains an open question as to why Bay of Bengal oxygen concentrations are higher than they are in the Arabian Sea despite the fact that the Bay of Bengal has lower local surface ventilation and older lower-oxygen source waters. Sediment-water interactions are potentially larger in the Bay of Bengal due to riverine input from the north and the extensive western shelf. Limited data make it challenging to determine whether annual rates of primary production and carbon/nitrogen export differ between the two basins despite likely higher primary production in the Arabian Sea during the SWM. Dust 
deposition is higher in the Arabian Sea, yet there is evidence for iron and silica limitation there from both models (Wiggert et al., 2006; Wiggert and Murtugudde, 2007; Koné et al., 2009; Resplandy et al., 2011) and observations (Moffett et al., 2015). Both basins experience lateral eddy ventilation from boundaries. These considerations lead to the following questions: What physical, chemical, and biological factors differentiate the biological pump in the Arabian Sea and Bay of Bengal? Why are the waters of the Bay of Bengal not as hypoxic/anoxic as the Arabian Sea? What are the global impacts of potential changes in upwelling (source of primary production), source waters (boundary $\mathbf{C}$ and $\mathbf{O}$ fluxes), mixing (vertical $\mathbf{O}$ and $\mathbf{C}$ fluxes), fresh water inputs from rivers (stratification) and sediment fluxes that might influence the spatial extent and activity of the OMZs and lead to changes in the sinks for $\mathrm{NO}_{3}$ and the sources of $\mathrm{N}_{2}$ and $\mathrm{N}_{2} \mathrm{O}$ in the northern Indian Ocean? How are changes in anthropogenic carbon and oxygen influencing the intensity of acidification, dissolution and the increase in alkalinity between the basins? How does OMZ intensity affect coastal ecosystems and fisheries via upwelling? What are the spatial and temporal extents of $\mathrm{Fe}$ and $\mathrm{Si}$ limitations in the northern Indian Ocean? Is the Bay of Bengal Fe- and/or Si-limited as well? How do these limitations impact the microbial food web and primary production that fuels biological oxygen demand?

\section{Implementation}

The processes influencing the northern Indian Ocean OMZs operate on scales that range from synoptic (e.g., submesoscale eddies and air-sea coupling, which are impacted by climate-driven variation in synoptic intensity) to seasonal (e.g., monsoons that drive boundary current reversals and dust/aerosol flux variability) to annual/interannual (e.g., Indian Ocean Dipole-driven thermocline fluctuations that impact nutrient upwelling and dust fluxes) to decadal/climate (which can result in changes in oxygen supply and demand, anthropogenic carbon uptake and alkalinity, and meridional overturning intensity and pathways). U.S.-led studies of the northern Indian Ocean OMZs could potentially address all of these timescales through a combination of biogeochemical profiling float, drifter and AUV (Autonomous Underwater Vehicle) deployments, shipboard sampling, and satellite and modeling studies, and by leveraging ongoing programs like IndOOS/RAMA, Argo (an international program that uses profiling floats to observe temperature, salinity, currents, and, recently, bio-optical properties in the Earth's oceans) and GO-SHIP. A few examples are provided below. Efforts should also be undertaken to leverage international partners' shiptime/experimental expertise, especially India. The IIOE-2 Endorsed Projects page (see http://www.iioe-2.incois.gov.in/IIOE-2/Endorsed_Projects.jsp) can be used to help determine what other groups are doing in the northern Indian Ocean so as to facilitate collaboration and leveraging of resources.

U.S.-led research could greatly accelerate the deployment of biogeochemical (BGC) Argo floats (Biogeochemical-Argo Planning Group, 2016) in the northern Indian Ocean to characterize the variability in physical and biogeochemical properties over synoptic to interannual timescales. The Arabian Sea and Bay of Bengal currently have a growing number of BGC-Argo floats carrying oxygen and optical sensors, but the regions need more of these floats for expanded coverage. Fully equipped BGC-Argo floats, with $\mathrm{O}_{2}$, 
$\mathrm{NO}_{3}, \mathrm{pH}$, fluorescence, backscatter and irradiance, would provide regional to basinscale estimates of net community production and ocean carbon parameters, including $\mathrm{pCO}_{2}$ and air-sea fluxes, as well as monitoring of oxygen throughout the OMZs. These deployments, combined with physical and biogeochemical measurements at the central Arabian Sea and Bay of Bengal (BOBOA (Bay of Bengal Ocean Acidification) mooring with biogeochemical sensors and MAP $\mathrm{CO}_{2}$ system) RAMA flux mooring sites, could provide a rich dataset and context for focused, process study cruises. These cruises could provide critically needed rate measurements of physical and biological processes (e.g., air-sea exchange, mixing, primary productivity, respiration, denitrification, $\mathrm{N}_{2}$ and $\mathrm{N}_{2} \mathrm{O}$ production, and carbon and nitrogen export). In addition, historical and upcoming GO-SHIP lines (e.g., I07N, which was occupied again in 2018, and I01E, which is possible but has not been funded) will continue to provide a large-scale, retrospective decadal/climate perspective on physical and biogeochemical variability. Future cruises could be leveraged to deploy BGC-Argo floats, which can also be deployed from other research cruises with water sampling for sensor validation. An effort should be mounted to occupy I01E (Fig. 4.4), either by India or the United States. This line is not only important for providing context for Bay of Bengal studies, but also for estimating fluxes across the boundary. A repeat of $101 \mathrm{~W}$ (Fig. 4.4) may not be feasible because the western (Somali) coast is still potentially inaccessible due to piracy issues.

Figure 4.4: Indian Ocean GO-SHIP lines.

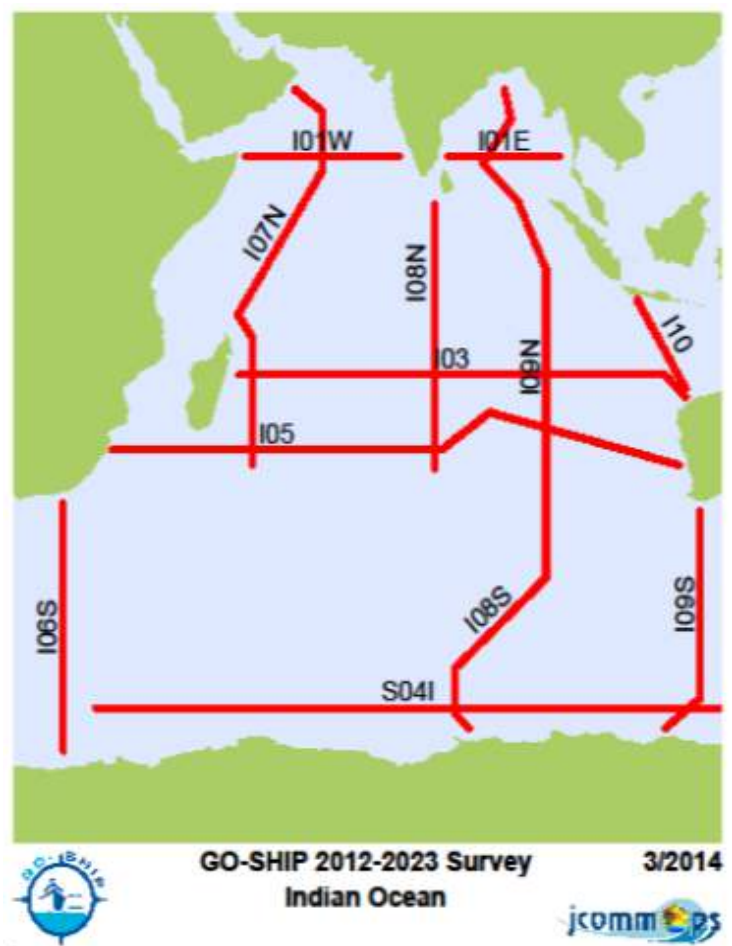

Process studies within the Arabian Sea and Bay of Bengal do not necessarily need to be contemporaneous. A sequence of cruises over multiple years could be proposed/undertaken to the central Arabian Sea and Bay of Bengal in different seasons to provide comparative measurements. (The assumption here is that, though the climate is changing, in a 5 to 10year time frame the system is relatively stable and that interannual variability will be relatively weak compared to the main background conditions.) Indeed, comparative studies aimed at examining the seasonal physical, biogeochemical and microbial variability of the OMZs would be valuable and unprecedented. Indian human resources and assets should be leveraged, perhaps in combination with German, French and Indian GEOTRACES, to execute a multilateral joint IIOE2/GEOTRACES process study that is focused on trace metals, rate processes and nutrient limitations. Short (3-5 stations) N-S oriented transects in the Arabian Sea and Bay of Bengal are preferred and likely most feasible, given exclusive economic zone (EEZ) restrictions. These transects could be "anchored" by GO-SHIP and GEOTRACES lines. Atmospheric measurements of aerosols, dust deposition, many of which are done on GEOTRACES cruises, should also be made. Comparative studies of the Arabian Sea and Bay of Bengal OMZs can leverage the recent ONR-funded MISO-BOB and NASCar studies to evaluate the 
physical impacts of mixing and air-sea exchange on upper ocean ventilation. ONR has collected and remains open to collecting biogeochemical measurements in its efforts.

Process studies are also needed along these lines to give a broader basin-wide context for variability in transport and biogeochemistry of source water masses into the northern Indian Ocean. Thermocline-oxycline relationships can be used in the equatorial Indian Ocean to estimate impacts of, for example, IOD on source water characteristics. Integrated modeling efforts could be motivated that complement process studies and link to basin-scale remote forcing factors. Models and state estimates, which combine models and observations, would be central for studies of carbon and oxygen fluxes in the Arabian Sea and Bay of Bengal (e.g., using NASA and UCAR (University Corporation for Atmospheric Research) biogeochemical models, HYCOM (Hybrid Coordinate Model) + offline biogeochemistry, and application of the mechanics of BSOSE (Biogeochemical Southern Ocean State Estimate) to the northern Indian Ocean, etc.).

U.S. research should also target improvements and enhancement in the sustained observing system (i.e., IndOOS/RAMA) to provide broader temporal and spatial coverage of physical and biogeochemical variability. OSSEs are needed to estimate how many measurements are required, and over what timescales, to resolve changes in $\mathrm{OMZs}$ and also to understand sensitivity to external forcing with uncharacterized variability. These kinds of studies can/should also utilize remote sensing measurements (e.g., SST, SSH (Sea Surface Height), SSS (Sea Surface Salinity), CDOM (Colored Dissolved Organic Matter), pigments, primary production). Proposals to NASA involving modeling and remote sensing that are aimed at evaluating uncertainties and aliases in observational studies and monitoring should be encouraged. Additional issues and challenges that could be addressed through NASA-funded research include the need to solve retrieval problems and errors caused by aerosols (anthropogenic and natural), and the need for better atmospheric corrections in both the Arabian Sea and the Bay of Bengal. In both basins, dust varies with the monsoons, which causes problems, in particular, for ocean color (e.g., limited or no retrievals in the Arabian Sea in June and July). NOAA RAMA-servicing cruises could also be leveraged to make additional measurements of optical properties, aerosols, water vapor, etc.

\section{Theme 5: Marine Geology and Deep Ocean Biogeochemistry and Ecology}

\section{Introduction}

The Indian Ocean offers a wealth of sub-seafloor targets that are unparalleled in other ocean basins. However, the many possible high-scientific value targets can be narrowed to three that maximize U.S. scientific interest, and uniqueness relative to other more accessible ocean basins. The targeted sites encompass a much wider spread of geographic localities and geological regimes than the recent IODP campaign (Legs 353362 ) in the Indian Ocean, as well as a recent French-led north south transect in the Bay of Bengal that performed deep coring, but did not sample the resident deep subsurface 
biosphere. These suggestions are distinct from the work to drill to the Mohorovicic discontinuity and the crust-mantle boundary with repeat visits through IODP.

\section{A) Crustal genesis, mantle processes, hydrothermal activity and the deep biosphere at the Ultraslow Spreading (14 mm/yr) Southwest Indian Ridge}

\section{Scientific Motivation}

The Southwest Indian Ridge offers a unique opportunity to understand the formation of ocean lithosphere and the most abundant magma type on Earth. Unlike at locations with faster spreading rates, the Southwest Indian Ridge, at $<20 \mathrm{~mm} / \mathrm{yr}$, contains midocean ridge basalts (MORB) whose composition reflects a thicker lithosphere and ultraslow mantle upwelling. The degree of mantle melting varies from near zero to $>15 \%$ at rates $<20 \mathrm{~mm} / \mathrm{yr}$ (Fig. 5.1), allowing identification of the contribution of the different components in a heterogeneous mantle to MORB, and how the process responds to ridge geometry and changes in mantle composition. Due to ultraslow spreading rates the extent of mantle melting is far more sensitive to variations in spreading rate, tectonic setting, mantle composition, and mantle potential temperature than at faster spreading ridges (e.g.: Bown \& White, 1994). It thus provides a remarkable opportunity to explore the relationship between mantle hot spots at Bouvet and Marion Islands and volcanism along the adjacent ocean ridge. The SW Indian Ridge also exhibits remarkable and extensive exposures of the abyssal mantle, making it the best place on Earth to study the oceanic upper mantle. No other accessible ridge provides so many opportunities to understand mantle dynamics, ridge tectonics, and generation of Earth's most abundant magma. The Southwest Indian Ridge also affords a unique opportunity to study the deep biosphere in the mantle exposed on the seafloor and the geochemical exchange between it and the ocean, which are largely unknown.

Twenty-six sites of suspected hydrothermal activity have been identified along the SW Indian Ridge (Fig. 5.2), although only one active site of high-temperature hydrothermal venting - the Dragon Flag or Longqi hydrothermal field - has been observed and sampled (Tao et al., 2011). Dragon Flag is hosted on the basaltic hanging wall of a detachment fault, and includes numerous active and inactive chimneys up to 20-m high, mounds, and large areas of diffuse flow. It appears similar in size, fluid chemistry and mineral deposits to the TAG hydrothermal field on the Mid-Atlantic Ridge (Jia et al., 2017). However, the complexity of the structure of the Southwest Indian Ridge and the diversity of geotectonic settings and substrates that might host both high- and lowtemperature hydrothermal systems makes it an excellent location to investigate the diversity of hydrothermal systems and their associated biological communities. Studies of the hydrothermal activity on the Southwest Indian Ridge will provide fundamental new knowledge on the biogeochemistry, community ecology and biogeography of these systems. 


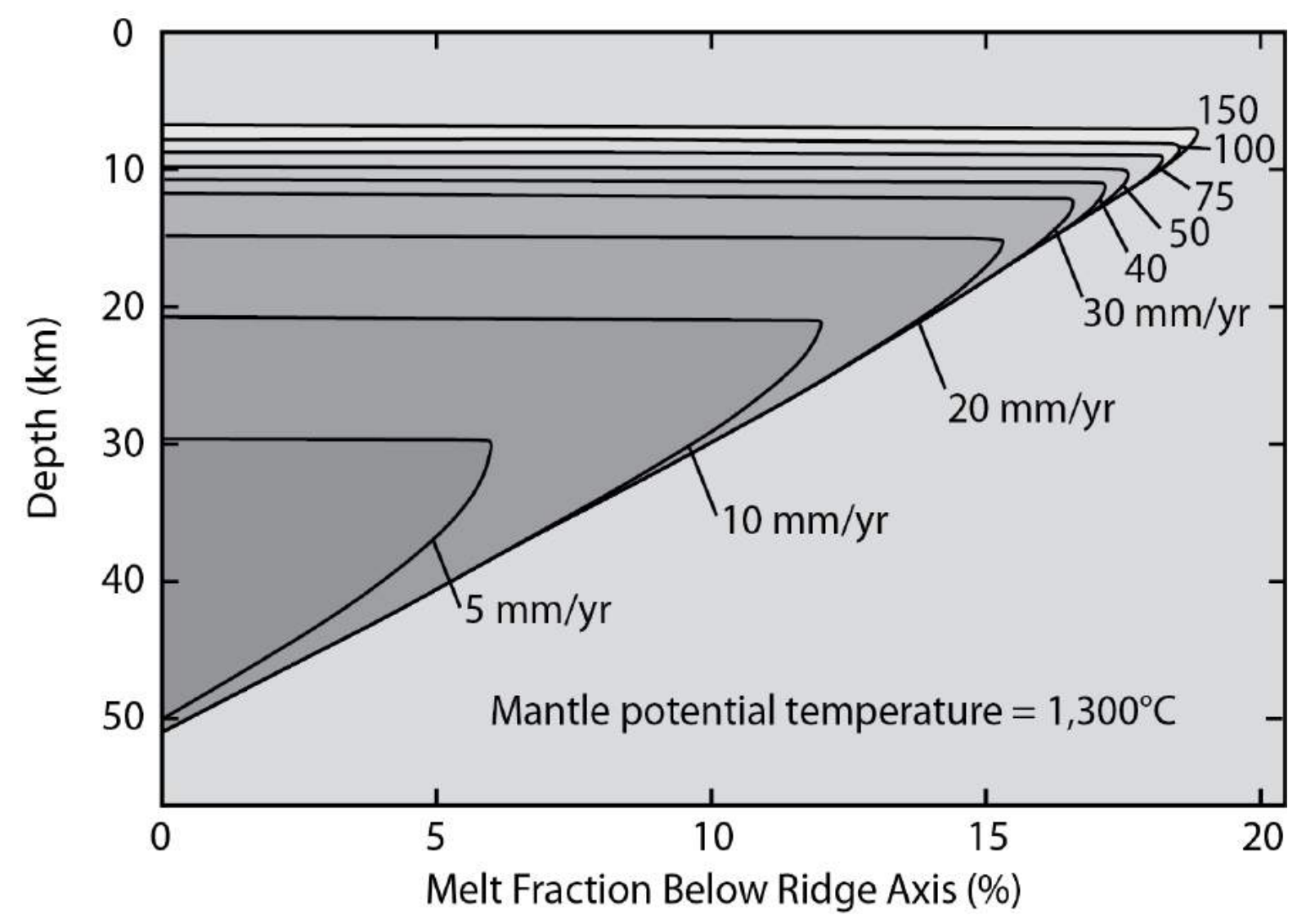

Figure 5.1: Predicted melt fraction against depth beneath spreading centers calculated for full spreading rates, as annotated on the curves for a mantle potential temperature of $1,300^{\circ} \mathrm{C}$. Curves show the marked increase with depth for the depth at which melting ceases with decreasing spreading rate below $20 \mathrm{~mm} / \mathrm{yr}$. Figure reprinted from Bown and White (1994), Copyright (1994), with permission from Elsevier.

\section{Societal Relevance}

Mid-ocean ridge studies have revolutionized our understanding of the geological and geophysical dynamics of the Earth, leading to the development of the theory of plate tectonics, which has influenced all branches of Earth science. But many questions remain about the formation of the ocean lithosphere and the currently unknown microbial ecosystems that may be supported by chemical interactions between mantle rocks and seawater. The Southwest Indian Ridge provides a unique opportunity to constrain the geochemical fluxes between the Earth's interior, crust, ocean and atmosphere, both as a potential sink for carbon, and for metals of economic interest over a broad range of crustal architecture ranging from broad regions tens of thousands of $\mathrm{km}^{2}$ in extent, where the mantle is exposed directly to the seafloor, to regions where the crust is up to 10-km thick. In addition, hydrothermal investigations on the Southwest Indian Ridge will advance our understanding of basic ocean biogeochemistry and ecology and they will very likely result in the discovery of new vent sites, communities and species. Hydrothermal systems hosted in mantle rocks could also shed new light on the potential role of hydrothermal activity in the evolution of life on Earth. 


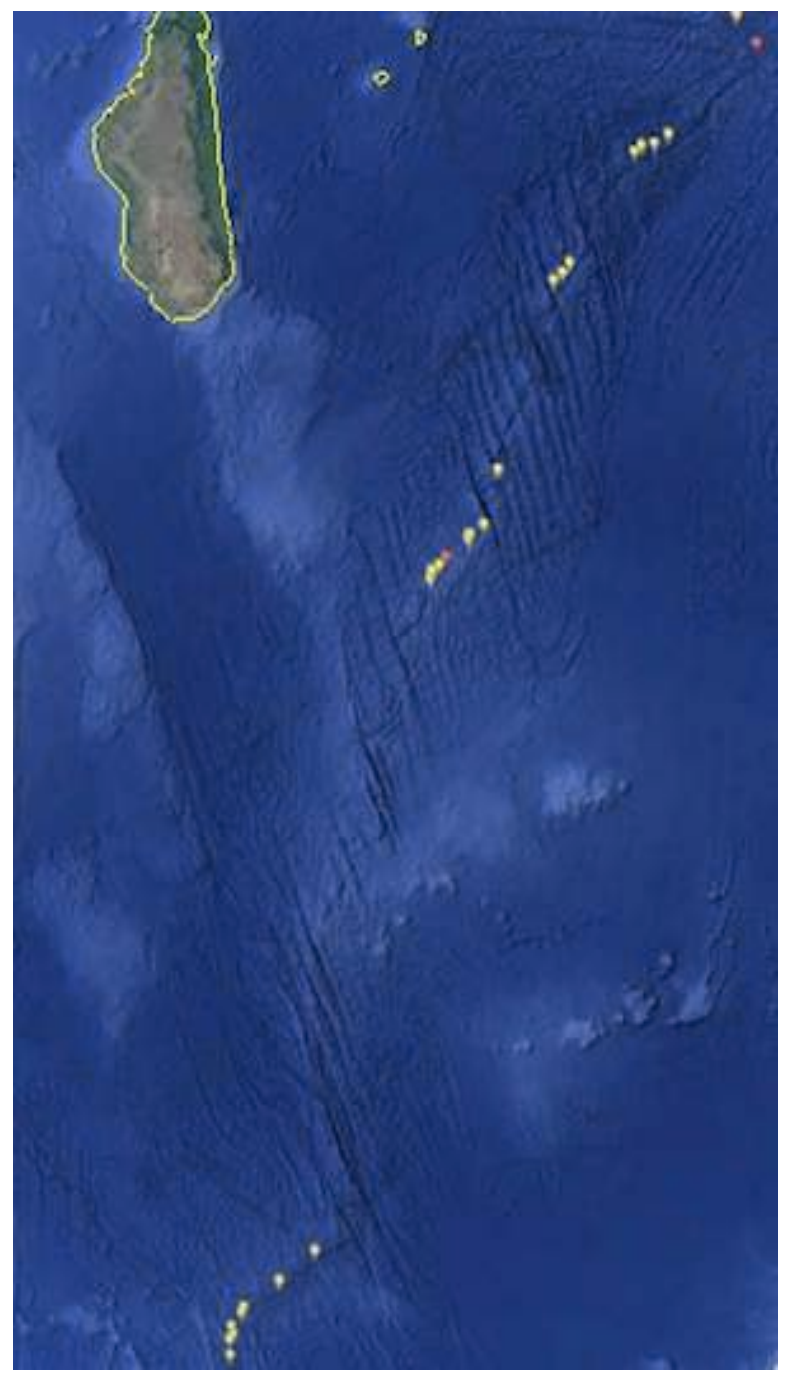

Figure 5.2: Locations of inferred hydrothermal activity on the Southwest Indian Ridge from the InterRidge Vents Database, visualized on Google Earth (Credit for KML file: S. Beaulieu, Woods Hole Oceanographic Institution, 2015; funding from U.S. National Science Foundation \#1202977).

\section{Scientific questions}

The U.S. IIOE-2 research strategy on the Southwest Indian Ocean Ridge should focus on the following fundamental questions to advance the integrated understanding of the geophysical, biogeochemical and ecological dynamics (including deep biosphere communities) of the region. What controls the local and regional variability of midocean ridge basalt and ridge tectonics, and how does this reflect mantle prehistory? How is the rock-hosted subsurface biosphere impacted by mantle below ocean crust in magmatic segments? How does chemical exchange during hydrothermal circulation affect the biogeochemistry and microbial ecology of the deep Indian Ocean water column? How do different rock substrates affect the nature and composition of hydrothermal mineral deposits? Do the micro and macro hydrothermal biological communities reflect different geochemical environments, or does biogeography (founders' effects) determine the community makeup?

\section{Implementation}

Previous expeditions have conducted systematic sampling along the Southwest Indian Ridge, but the wide spacing of samples (rarely $<70 \mathrm{~km}$ ) is inadequate to understand local geochemical variability and the response of crustal accretion to ridge dynamics. Previously sampled basalts are virtually all capping lavas from neovolcanic zones, leaving the rift-mountains, their exposures of lower crust and mantle and the full variability of MORB unknown. The conclusion that only $5 \%$ of the crust is gabbro (mafic intrusive igneous rock that is a chemically equivalent coarse-grained analogue to basalt) is almost entirely based on sampling fracture zones. Fracture zones, however, represent a unique ridge environment: understanding the nature of the crust and mantle requires much additional sampling parallel to ridge segments on rift valley walls and offaxis where deep crust and mantle are exposed to obtain a more fully representative sample suit. The many large fracture zones, though, with their rough topography enable 
timeline studies. Initially, swath bathymetric mapping and sampling along 300-km flow lines across axis should be made, with a focus on the poorly mapped and sampled central region of the ridge $\left(30^{\circ}-56^{\circ} \mathrm{E}\right)$. Dredging with MAPR's (self-contained instruments with temperature, pressure, and nephelometer sensors) will allow detection of hydrothermal plumes. Based on these results, seafloor sampling and high-resolution mapping by ROVs (Remotely Operated Vehicles) and AUVs, as well as water-column sampling in key target areas, would follow on later cruises. Biosphere sampling could be conducted alongside all geological expeditions that are equipped for rock and water recovery.

Studies of hydrothermal activity on the Southwest Indian Ridge should be coordinated with geological and subsurface biosphere objectives to take advantage of the previously collected MAPR data at both on- and off-axis locations. This information, combined with already suspected hydrothermal locations, should be used to develop a nested strategy approach to target specific regions representing diverse geotectonic environments based on the mapping and sampling program described above. As an initial step, CTDs fitted with redox sensors and transmissometers should be used to conduct surveys to further narrow the likely location of hydrothermal fields. This could be followed by high-resolution $(\sim 1 \mathrm{~m})$ bathymetric mapping using AUV's with hydrothermal sensors for each area. This would enable hydrothermal structures (mounds, chimneys) to be identified for further investigation as well as rock, fluid, and biological sampling using ROV's.

\section{B) Deep subsurface sediments of the Bengal and Indus Fans}

\section{Scientific Motivation}

The Indus and Bengal fans are the two largest submarine sediment repositories - the resting place of the eroded Himalayas (Fig. 5.3). This Indian Ocean sector has ultrahigh sedimentation rates with organic-rich sediments contributing to fan deposits sequestering up to $20 \%$ of the mass of the total terrestrial organic matter buried in marine sediments (Galy et al. 2007). This is a completely unexplored habitat for the deep biosphere, and likely increases our global estimates of its biomass, which are based on models that do not incorporate data from fan systems (Kallmeyer et al. 2012).

\section{Societal Relevance}

Studies of the deep biosphere in these fans will contribute greatly to our current understanding of the importance and diversity of the relatively recently discovered, but globally important deep subsurface biome, and will contribute to understanding the diverse environments that can support life on Earth and other planets, as well as constrain sedimentary carbon cycling on Earth.

\section{Scientific questions}

The U.S. IIOE-2 research strategy should focus on the following questions to understand the subsurface biosphere: Do potentially high microbial cell numbers in 
the Bengal and/or Indus fans alter global estimates of the marine deep subsurface biosphere's size? Do subsurface microbial populations respond to long-term exposure to elevated organic matter content in an anoxic environment? Do sedimentary microbial communities in these fans respond to monsoon cycles in a consistent way over the entire northern basin? Do they and the biogeochemistry vary across sediments underlying swaths of the oxygen minimum zones?
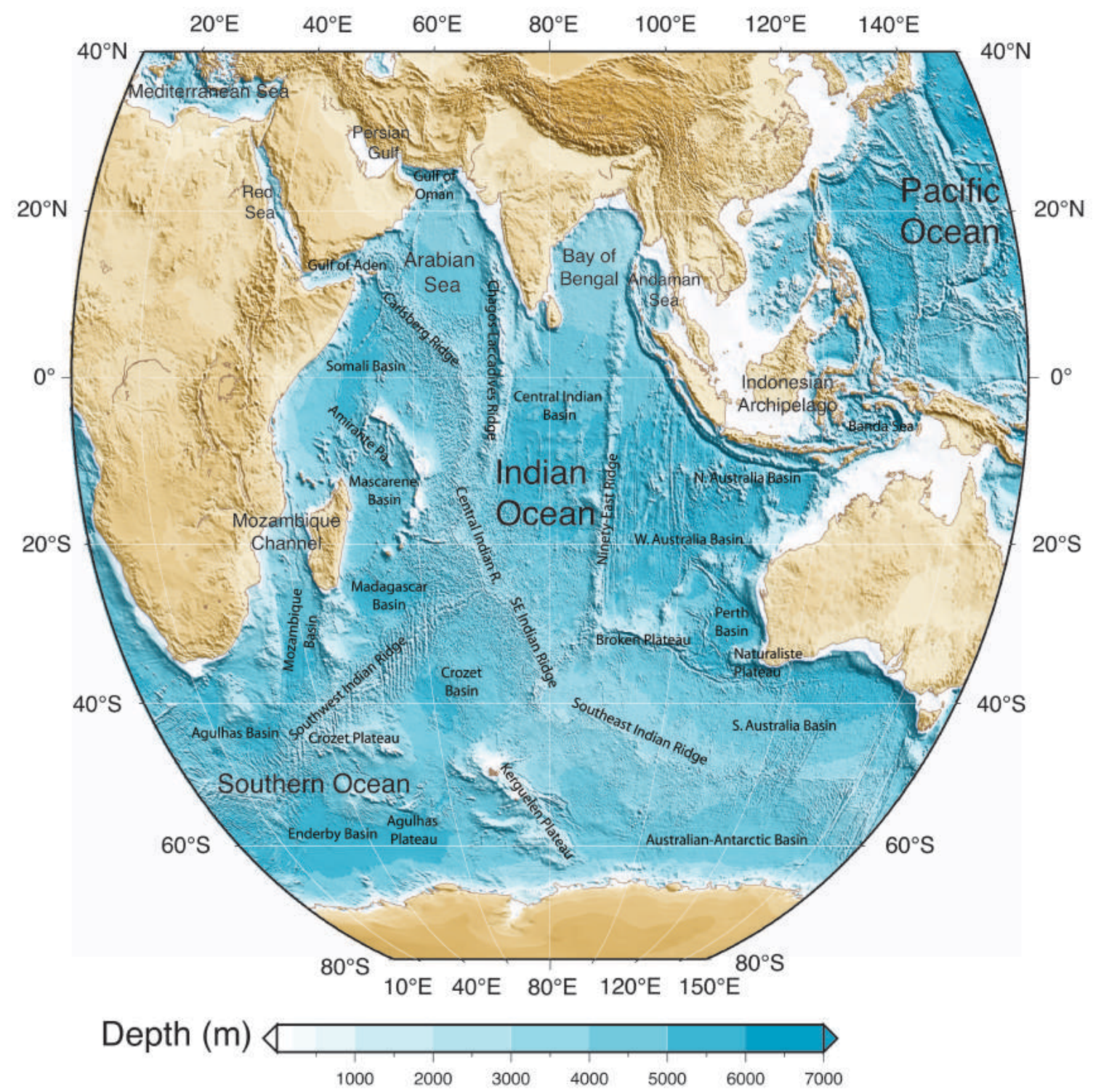

Figure 5.3: Map of Indian Ocean topography, derived from Etopo2 bathymetry data from NOAA NGDC. Reprinted from Talley et al. (2011), with permission granted by the author.

\section{Implementation}

This research would be greatly facilitated by regaining U.S. long-coring capabilities lost with decommissioning the $R / V$ Knorr. Otherwise, scientists are limited to infrequent 
IODP expeditions or sub-ten meter gravity coring. Sampling platforms preferably would have clean labs for culturing, or pressurized core retrieval. Piggybacking coring operations on water column cruises is impractical; GEOTRACES has demonstrated the difficulty of doing this on water sampling CTD-driven cruises. Physical oceanographers actively studying the northern Indian Ocean on recent U.S.-India cruises, also confirm this incompatibility. Thus, dedicated coring expeditions are needed, with possible synergies with geologists who need cores. These cruises could focus on systematic sampling of north-south and east-west organic matter gradients, possibly starting in the Bay of Bengal. Previous biogeochemistry and physical oceanography cruises show that tracks can be chosen at least partially avoiding EEZs and high-piracy areas. IIOE-2 begins with a solid geophysical knowledge of Indian Ocean fans from IIOE-I and more recent IODP efforts. In addition, a GEOTRACES-style standardization of sample measurements for all sediment coring would help comparisons with the similar basin, the Arabian Sea.

\section{C) Regional tectonics of the Northern Indian Ocean}

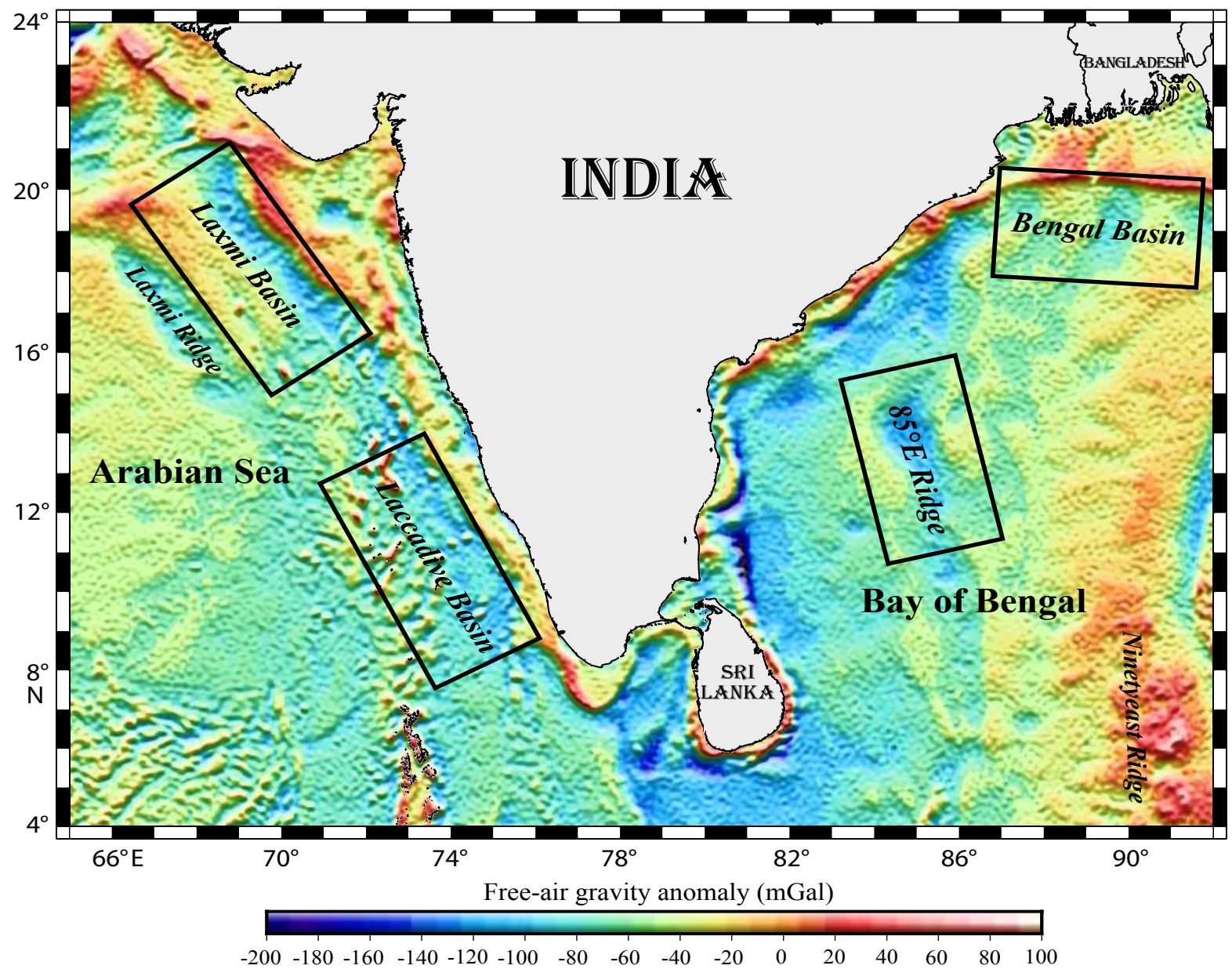

Figure 5.4: Satellite-derived free-air gravity anomaly map of the northern Indian Ocean. Boxes show the locations of study regions for carrying out detailed seismic refraction and magnetotelluric investigations. The image was provided by K. S. Krishna, University of Hyderabad, India. The map was generated using global grids of gravity anomalies described in Sandwell et al. (2014). 


\section{Scientific Motivation}

The Indian Western Continental Margin was shaped by excessive magmatism, multiple rifting episodes, and mantle plumes. Existing magnetic, gravity and seismic reflection data have led to competing evolutionary models on the nature of the lithosphere, magmatic activity, and sedimentation in the region (Talwani and Reif, 1988; Todal and Eldholm, 1988; Bhattacharya et al., 1994; Krishna et al., 2006). Studies of the Laxmi and Laccadive basins are needed to understand these processes and the nature of the crust (Fig. 5.4). The nature of the crust beneath the northern Bay of Bengal, particularly the Bangladesh margin, is also ambiguous (Fig. 5.4). A unified model for the nature of crust would allow precise plate reconstructions for Greater India and East Antarctica. The $85^{\circ} \mathrm{E}$ Ridge and the associated prominent negative gravity anomaly in the western Bay of Bengal is a major unsolved enigma (Fig. 5.4): What is its structure; its origin; is it loading the crust; why is there a negative gravity anomaly; and how does it fit into global plate reconstructions? Several countries, including India and Australia, have extensively studied continental margins, ocean basins, and deep-water regions with conventional magnetics, gravity and seismic reflection. These tools fail to resolve geological complexities. Therefore, our target areas need new geophysical approaches, such as seismic refraction with ocean bottom seismometers, and magnetotellurics.

In addition, the large Indian Ocean Indo-Australian plate is breaking into three subplates with diffuse boundaries (Royer and Gordon, 1997) (Fig. 5.5) with different styles and timing of seismicity and deformation (Krishna et al., 2001, 2009; Sager et al., 2013; Singh et al., 2017). This is not well documented across the boundary from the Central Indian Ridge to the trench.

\section{Societal Relevance}

Fundamental questions remain about the geological processes in the northern Indian Ocean. Studying the nature of the western continental margin, the Bay of Bengal and the structure of the Indo-Australian plate will advance our fundamental understanding of the formation of Earth's crust, improving plate tectonic models in a complex undersampled region, and facilitate prediction of devastating earthquakes and tsunamis around the Indian Ocean rim.

\section{Scientific questions}

U.S. IIOE-2 strategy should focus on these questions: How did the diffuse plate boundary from Central Indian Ridge to the Sunda subduction zone evolve? How and where are micro-continents like Elan Bank and Southern Kerguelen Plateau split from the Indian subcontinent? What is the structure and evolution of the $85^{\circ} \mathrm{E}$ Ridge? What is the nature of the crust beneath the Bangladesh Margin, the Laxmi and Laccadive Basins? 


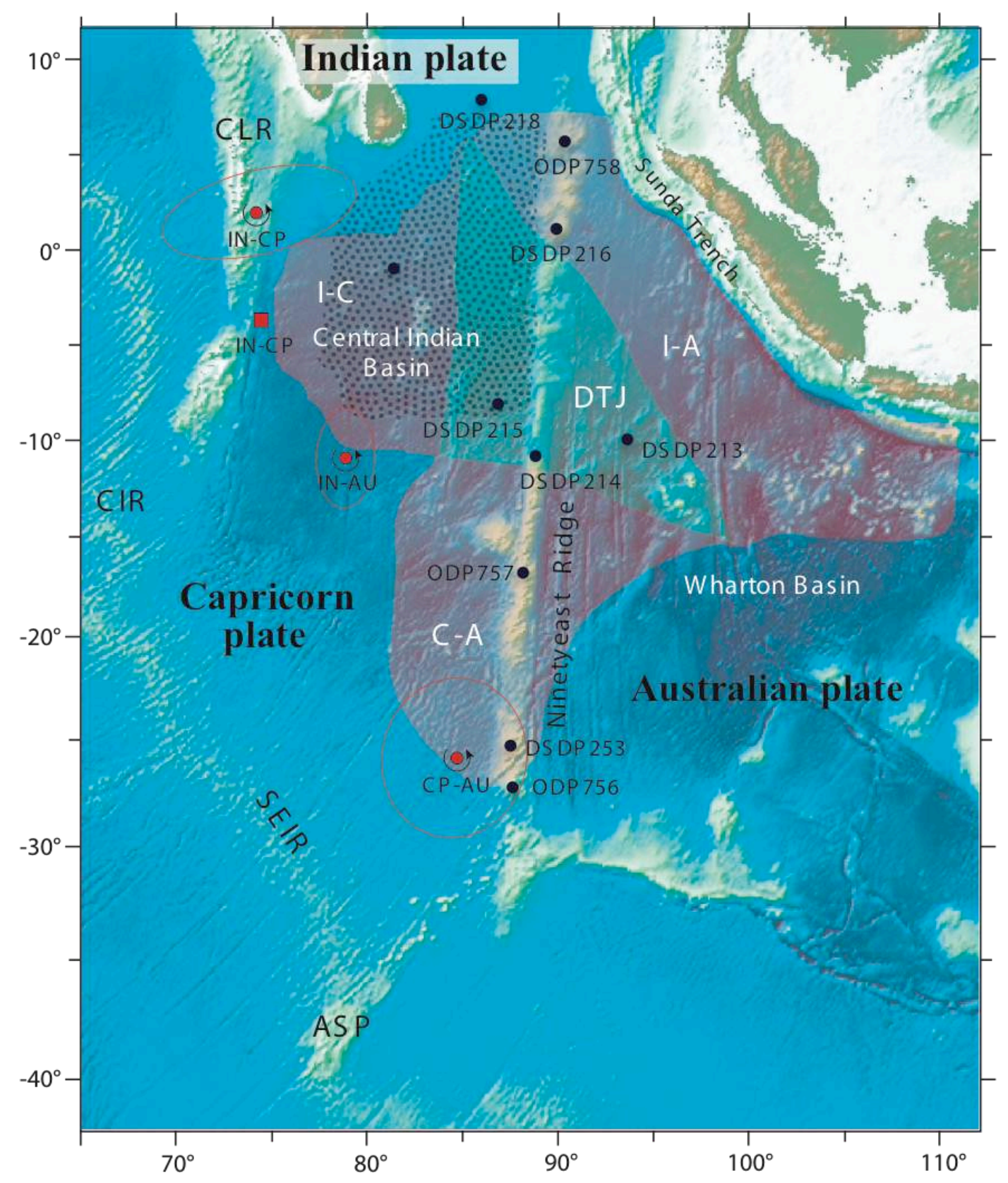

Figure 5.5: General seafloor map of the central Indian Ocean, including three sub-lithospheric plates (Indian, Capricorn and Australian) and diffuse plate boundaries. From Royer and Gordon (1997). Reprinted with permission from AAAS. Stippled zone in the Central Indian Basin shows lithospheric compression from India-Capricorn convergence (Krishna et al., 2001, 2009). Reprinted with permission of the Geological Society of America.

\section{Implementation}

The target areas first need extensive geophysical characterization, followed by drilling in the Bengal Fan, south of Sri Lanka, and along the Indian margins. India has extensive facilities and experienced geophysicists in general seismology of terrestrial and marine settings who seek collaborative use of specialized U.S. tools and methodologies (e.g., 
ocean bottom seismometers, magnetotellurics, and deep multichannel seismics). They have generous ship time analogous to UNOLS (University-National Oceanographic Laboratory System), and U.S. efforts should take full advantage of Indian interests, assets and human resources with bilateral proposals and programs encouraged. These will ease restrictions on access to target areas overlapping with the Indian EEZ (Fig. 5.4). This could couple sample sharing with those interested in the $3-4 \mathrm{~km}$ of sediments overlying the Indus and Bengal fan basement, while water column-focused cruises can be leveraged to obtain shallow mono-push cores of surface sediments for initial microbiological and biogeochemical data (Section 5C).

\section{Strategy for Obtaining Funding}

The funding model for U.S. IIOE-2 will follow that established by the ongoing GEOTRACES program, to submit coordinated proposals to both federal and private agencies. The U.S. IIOE-2 Steering Committee will help motivate and coordinate U.S. IIOE-2 proposal development and submission. A key aspect of this funding model is raising awareness among these agencies about IIOE-2, the U.S. IIOE-2 initiative, and the U.S. IIOE-2 research priorities that are identified in this document.

The U.S. research emphasis on upwelling, inter-ocean exchanges, monsoon dynamics, inter-basin contrasts, marine geology and the deep ocean will complement and significantly expand the scope of the international effort. Any of these themes could be developed and proposed to U.S. funding agencies as a focused U.S. research program. The following articulates strategies for obtaining federal support to carry out research under each Theme.

Theme 1 (Physical, Biogeochemical and Ecological Dynamics of the SeychellesChagos Thermocline Ridge) is the subject of ongoing bilateral exchanges between the U.S. and South Korean research community that were initiated in 2017 by NOAA. These exchanges are aimed at formulating a Science Plan to guide South Korean participation in IIOE-2. A bilateral workshop was convened in Seoul, on November 29 to December 1, 2017. The science plan that emerged from this workshop recommends that a joint South Korean and U.S. research initiative should be motivated as part of IIOE-2 focusing on the Seychelles-Chagos Thermocline Ridge (McPhaden et al., 2018). The motivations and research questions articulated in this plan are similar to those that are articulated in Theme 1 above. A second bilateral workshop will be convened in San Diego (at Scripps Institution of Oceanography) on November 6-8, 2018 that is aimed at formulating research proposals for submission to South Korean and U.S. funding agencies. U.S. scientists who are interested in pursuing research under Theme 1 should participate in this bilateral planning process and second workshop, with potential proposal submissions to U.S. federal agencies (NSF, NOAA and NASA) anticipated in 2019.

Theme 2 (Physical and Biogeochemical Budgets and Exchanges) is unique in that it articulates what might be considered one large coordinated program that could be funded through a single proposal or a few coordinated proposals in cooperation with 
measurements made by other countries (e.g., South Africa and Australia). The U.S. IIOE-2 Steering Committee will work to motivate and coordinate proposal(s) related to Theme 2. U.S. Scientists that are interested in pursuing research related to this theme are encouraged to contact the U.S. IIOE-2 Steering Committee so that it can help coordinate proposal development and submission. Relevant units within NSF include the Physical Oceanography and Chemical Oceanography programs in the Ocean Sciences division. Relevant units within NOAA include the Office of Oceanic and Atmospheric Research and the Climate Program Office.

Theme 3 (Monsoon Dynamics) is probably the broadest. U.S. Scientists that are interested in pursuing research related to this theme should formulate proposals for submission to NSF's Atmospheric and Geospace Sciences, Earth Sciences and Ocean Sciences Physical Oceanography programs, and also to NOAA's Office of Oceanic and Atmospheric Research and their Climate Program Office. Research proposals related to this theme that focus on using remote sensing data should formulate proposals for submission to NASA's Earth Science Division. The Weather, Climate Variability and Change, and the Water and Energy Cycle research focus areas are particularly relevant. Research in the Indian Ocean related to air-sea exchange processes and upper-ocean physical dynamics has been funded by previous and ongoing ONR programs (e.g., Forced Upper-Ocean Dynamics Experiment, ASIRI, MISO-BOB and NASCar). Opportunities for additional funding can be ascertained by contacting the relevant ONR program managers.

Theme 4 (Physical, Biogeochemical and Ecological Contrasts Between the Arabian Sea and the Bay of Bengal) is, perhaps, the research theme with the most relevance to the Ocean Carbon and Biogeochemistry (OCB) Program (us-ocb.org), which is supported by the NSF Chemical and Biological Oceanography programs and NASA's Ocean Biology and Biogeochemistry program. The focus of OCB is on promoting the study of marine ecosystems and biogeochemical cycles in the face of environmental change. U.S. scientists that are interested in pursuing research related to Theme 4 should formulate proposals for submission to these programs. Interdisciplinary proposals should also consider submission to NSF's Physical Oceanography program and/or relevant NASA Physical Oceanography research focus areas. Coordinated proposal submissions in the 2018 and 2019 are strongly encouraged. The U.S. IIOE-2 Steering Committee intends to focus its advocacy in OCB for research related to this theme.

Theme 5 (Marine Geology and Deep Ocean Biogeochemistry and Ecology) is primarily a geological and geophysical research theme, though with biological and biogeochemical elements related to hydrothermal vents and the deep biosphere. U.S. Scientists that are interested in pursuing research related to this theme should formulate proposals for submission to Marine Geology and Geophysics program (division of Ocean Sciences) in NSF. Interdisciplinary proposals involving hydrothermal vent and/or the deep biosphere should also consider submission to NSF's Chemical Oceanography and/or Biological Oceanography programs. Coordinated proposal submissions in the 2018 and 2019 are also strongly encouraged. The U.S. IIOE-2 Steering Committee will establish a subcommittee dedicated to motivating and coordinating proposal submissions under this theme. 
U.S. Scientists are also encouraged to seek funding to support U.S. IIOE-2 research through private sources. For example, the Moore Foundation supports oceanographic research related to marine microbiology, ecology and metabolism, marine genetic diversity, and also marine technology development. Funding from the Moore foundation could, for example, potentially be obtained to support microbiological research in the northern Indian Ocean OMZs related to Theme 4. The Schmidt Ocean Institute provides state of the art operational, technological, and informational support to ocean science and technology development projects at sea. This support includes deep-sea environments. Funding from the Schmidt Ocean Institute could potentially be obtained to support any of the U.S. IIOE-2 research themes. Proposals aimed at undertaking some of the biogeochemical and ecological research in hydrothermal vents identified under Theme 5 might be particularly good candidates for submission to the Schmidt Ocean Institute. U.S. scientists should contact these and other relevant foundations and institutes to obtain information related to funding priorities and proposal submission deadlines.

Efforts are currently being undertaken by the U.S. IIOE-2 Steering Committee to raise awareness in all of these foundations and agencies of IIOE-2 and the U.S. research priorities that are articulated in this document. The U.S. IIOE-2 Steering Committee will assist with proposal development and coordination for all of the research themes.

Finally, it is important to emphasize that U.S. proposals that do not fall under the five U.S. research themes should also be considered for funding as part of U.S. IIOE-2. There are many important scientific questions that need to be addressed in the Indian Ocean that are outside the scope of the U.S. themes. The U.S. IIOE-2 Steering Committee will work to facilitate and coordinate all U.S. funded research in the Indian Ocean.

\section{Training, Education and Outreach}

The IIOE-2 is designed to build and expand research capacity in the international community and especially among developing Indian Ocean rim nations by promoting training courses to develop multidisciplinary science skills, workshops, summer schools and a program of personnel exchange. U.S. participation in IIOE-2 will create many opportunities to bring students and scientists from Indian Ocean rim nations onboard U.S. research vessels for training and education and it will also create many opportunities for outreach.

U.S.-funded research projects should seek to engage Indian Ocean scientists and associated institutions from developed and developing countries that are planning to undertake science activities in the region. U.S. IIOE-2 proposals should include training, education and outreach components that will accomplish collaborative use of expertise and physical resources from within and outside the Indian Ocean region. These kinds of activities could, for example, be incorporated into "broader impacts" components of submitted proposals. 
Examples of potential training, education, and outreach activities include:

- Creating online workshops/courses for educators in the United States and in the Indian Ocean region that are designed to reach K-12 educators and other interested participants, such as university students and faculty, policymakers and industry representatives;

- Developing environmental "Report Cards" for the Indian Ocean for communication and education - environmental report cards synthesize data from scientists and volunteers and convert it into an image-rich format that is easily accessible to a broad audience;

- Formulating Ocean Literacy Principles for the Indian Ocean and creating a guide for the Indian Ocean based on the current ocean literacy guide (see http://oceanliteracy.wp2.coexploration.org/);

- Developing curricula for schools and teachers that include educational resources, highlighting IIOE-2 research findings, which could be posted online and used by teachers in their classrooms or other educational settings;

- Connecting science experts with the education community through transdisciplinary education programs and science communication methods that engage students, educators, and the public in IIOE-2 expeditions.

Development of these types of training, education and outreach activities could be facilitated by partnering with organizations like the University of Maryland Center for Environmental Science Integration and Application Network (IAN), which provides science communication services and environmental report card production and training (see http://ian.umces.edu/), and/or the College of Exploration, which specializes in the development of ocean science and environmental education programs, particularly teacher professional development and organizational training, global ocean literacy development, program evaluation, and educational research (for more information, visit http://www.coexploration.org/).

Proposed training, education and outreach activities could also be linked to ongoing NOAA-sponsored capacity development programs in the Indian Ocean (see capacity development under https://cpo.noaa.gov). In addition, IOC, SCOR and POGO are pursuing a variety of international training, education and outreach activities under IIOE2 that could be leveraged by U.S.-funded efforts. For example, the IOC's International Oceanographic Data and Information Exchange (IODE) has established a network of regional training centers, several of which are located in the Indian Ocean Region (Kenya, Mozambique, India and Malaysia) that could be leveraged by U.S.-funded IIOE2 research projects to build capacity in nations contributing to IIOE-2 research efforts. The IODE Ocean Teacher Global Academy is another IODE training platform that can be leveraged by U.S. projects at the regional level. SCOR's current activities in capacity building focus on travel support to scientific meetings, training in oceanographic observations (with POGO), and SCOR Visiting Scholars. SCOR-sponsored research 
programs (the Integrated Marine Biosphere Research (IMBeR) project, the Surface Ocean Lower Atmosphere Study (SOLAS), and GEOTRACES each have their own capacity building experience and approaches that can also be leveraged by U.S.-funded IIOE-2 research projects.

Through these efforts, U.S. participants in IIOE-2 can provide an important vehicle to help the international community build research capacity in Indian Ocean rim nations and promote the long-term sustainability of this capacity.

\section{Data Policy}

U.S. IIOE-2 investigators will be expected to follow current best-practice recommendations for sharing research results. Most U.S. federal funding sources (e.g., NSF, NASA, NOAA and ONR) have written policies describing expectations for making data and research results publicly available in a timely manner following conclusion of the proposed research. For example, NSF-funded IIOE-2 investigators will be required to conform to the National Science Foundation Division of Earth Sciences (EAR) datasharing policy and/or Division of Ocean Sciences (OCE) Sample and Data Policy. The overall purpose and fundamental objective of both policies is to ensure and facilitate full and open access to quality data for research and education in the Earth Sciences. The following core elements of the EAR data-sharing policy summarize the requirements:

1. Preservation of all data, samples, physical collections and other supporting materials needed for long-term earth science research and education is required of all researchers.

2. Data archives must include easily accessible information about the data holdings, including quality assessments, supporting ancillary information, and guidance and aids for locating and obtaining data.

3. It is the responsibility of researchers and organizations to make results, data, derived data products, and collections available to the research community in a timely manner and at a reasonable cost.

4. Data may be made available for secondary use through submission to a national data center, publication in a widely available scientific journal, book or website, through the institutional archives that are standard for a particular discipline (e.g., IRIS (UCI machine learning repository) for seismological data, UNAVCO (a data center that handles data management tasks for GPS data and products) for GPS (Global Positioning System) data, IEDA (Interdisciplinary Earth Data Alliance) for marine geology data and sample metadata, BCO-DMO (Biological and Chemical Oceanography Data Management Office) for water column data).

5. For those programs in which selected principle investigators have initial periods of exclusive data use, data should be made openly available as soon as possible, but no later than two (2) years after the data were collected. This period may be extended under exceptional circumstances, but only by agreement between the Principal Investigator and the funding agency. For continuing 
observations or for long-term (multi-year) projects, data are to be made public annually.

6. Data inventories should be published or entered into a public database periodically and when there is a significant change in type, location or frequency of such observations.

The principles behind the OCE policy are similar to those of EAR, with additional specifications for more types of research products, including requirements that metadata files, full data sets, derived data products and physical collections must be made publicly accessible within two (2) years of collection. This includes software and derived data products (e.g., model results, output, and workflows).

For details see: https://www.nsf.gov/geo/ear/2010EAR_data_policy_9_28_10.pdf and https://www.nsf.gov/pubs/2017/nsf17037/nsf17037.pdf.

Additionally, investigators will be encouraged to work with data centers and publishers to acquire Digital Object Identifiers (DOIs) to uniquely identify all research products (e.g., data and publications), and to submit data and other research products to NCEI (National Centers for Environmental Information, https://www.ncei.noaa.gov/archive) for permanent archive.

\section{Leveraging and Coordination}

U.S. IIOE-2 will generate multidisciplinary links among marine geologists, atmospheric scientists, biological, chemical and physical oceanographers in the U.S. and internationally, building upon the research experience of past projects such as the JGOFS (Joint Global Ocean Flux Study) Arabian Sea Process Study, and the World Ocean Circulation Experiment (WOCE). U.S. IIOE-2 will also build upon and directly leverage recent and ongoing U.S.-funded research programs such as the ONR-funded ASIRI, MISO-BOB and NASCar projects in the Bay of Bengal and Arabian Sea, the NOAA-funded RAMA mooring array measurements in the tropical and subtropical Indian Ocean, and the NSF-funded ASCA Agulhas Current mooring array in the southwestern Indian Ocean. U.S. IIOE-2 will also build upon and leverage International programs such as the CLIVAR/IOGOOS Indian Ocean Observing System, GEOTRACES, the Global Ocean Ship-Based Hydrographic Investigations Program, the International Ocean Discovery Program, and InterRidge.

U.S. IIOE-2 studies in the Indian Ocean should also take full advantage of remote sensing programs and measurements to characterize physical and biological variability in the ocean and on adjacent landmasses. Relevant U.S. NASA measurements include satellite ocean color (retrospective SeaWiFS (Sea-viewing Wide Field-of-view Sensor) and MODIS-Aqua (Moderate Resolution Imaging Spectroradiometer; Aqua-PM Equatorial Crossing)), sea surface temperature (NOAA/AVHRR (Advanced Very High Resolution Radiometer), MODIS-Terra/Aqua (Terra-AM Equatorial Crossing)), sea surface height (Satellite Altimeters; Topex/Poseidon and Jason), surface vector winds 
(International Space Station (ISS) Scatterometer; ISS-RapidScat) and precipitation (Global Precipitation Mission, GPM).

Coordination among U.S.-funded efforts and with other national and international efforts will be vital to the success of U.S. IIOE-2. U.S. IIOE-2 PIs will need to be aware of all U.S.-funded research in the Indian Ocean and also the activities of many other national and international Indian Ocean research programs and integrate with them where appropriate. This coordination will be facilitated by the U.S. IIOE-2 Steering Committee, which has also tasked itself to do the following:

- Coordinate ongoing U.S. research in the Indian Ocean region and coordinate planning of new research;

- Provide a forum for interagency discussions of Indian Ocean research and a liaison between the scientific community and agencies;

- Communicate U.S. research in the Indian Ocean region to national and international audiences through a Web site, newsletters, articles in the peerreviewed and grey literature, social media, and other approaches;

- Represent the U.S. community on the international IIOE-2 Steering Committee and in international IIOE-2 meetings and discussions;

- Liaise with U.S. SCOR and IOC committees.

The U.S. IIOE-2 Steering Committee will work to improve the integration of existing and planned studies. This includes increasing the promotion of crosscutting science activities and the exchange of personnel, expertise, methodology, data and equipment. This should increase the efficiency and scientific value of the individual-projects. Toward this end, the U.S. IIOE-2 Steering Committee has helped develop an inventory of ongoing and planned international and U.S. IIOE-2-related research activities that is now maintained by the IIOE-2 Joint Program Office.

\section{Conclusions and Legacy}

U.S. IIOE-2 motivation, coordination and integration of Indian Ocean geologic, oceanographic and atmospheric research will advance our knowledge of this undersampled basin and provide an important scientific contribution to the larger international effort. The U.S. research emphasis on upwelling, inter-ocean exchanges, monsoon dynamics, inter-basin contrasts, marine geology and the deep ocean will complement and significantly expand the scope of the international IIOE-2 effort helping to create a lasting legacy on which future research can build. The data, reports and papers produced by the U.S.-funded effort will inform scientists in the international community and provide a focus for future research on important regional, basin-wide and global issues. In the global context, U.S. IIOE-2 will help provide a mechanism for facilitating the development of research and monitoring infrastructure and human resources in the Indian Ocean and it will also help to inspire a new generation of U.S. scientists who are interested in studying and understanding the Indian Ocean and its role in the global ocean and the Earth System. 


\section{References}

Alexander, D., A. Ameer, B. Rupakjyoti, F. Vivian Louis, G. Sandy, L. O. David, H. Jasmine, H. A. John, H. J. Paula, T. Jacob, G. L. Leighton, O. L. Ciara, D. R. Sergei, and A. R. David. 2012. "Indian Ocean: A Sea of Uncertainty." In Independent Strategic Analysis of Australia's Global Interests. Perth Australia: Future Directions International.

Alford, M. H., M. C. Gregg, and M. Ilyas. 1999. 'Diapycnal mixing in the Banda Sea: Results of the first microstructure measurements in the Indonesian Throughflow', Geophysical Research Letters, 26: 2741-44.

Alory, G., S. Wijffels, and G. Myers. 2007. 'Observed temperature trends in the Indian Ocean over 1960 - 1999 and associated mechanisms', Geophysical Research Letters, 34: Art. No. L02606.

Ayers, J. M., P. G. Strutton, V. J. Coles, R. R. Hood, and R. J. Matear. 2014. 'Indonesian throughflow nutrient fluxes and their potential impact on Indian Ocean productivity', Geophysical Research Letters, 41: 5060-67.

Bange, H. W., and et. al. 2000. 'A revised nitrogen budget for the Arabian Sea', Global Biogeochemical Cycles, 14: 1283-97.

Bange, H. W., S. Rapsomanikis, and M. O. Andreae. 2001. 'Nitrous oxide cycling in the Arabian Sea', Journal of Geophysical Research. C. Oceans, 106: 1053-65.

Bange, H. W., T. Rixen, A. M. Johansen, R. L. Siefert, R. Ramesh, V. Ittekkot, M. R. Hoffmann, and M. O. Andreae. 2000. 'A revised nitrogen budget for the Arabian Sea', Global Biogeochemical Cycles, 14: 1283-97.

Beal, L. M., W. P. M. De Ruiter, A. Biastoch, R. Zahn, and SCOR/WCRP/IAPSO_Working_Group_136. 2011. 'On the role of the Agulhas system in ocean circulation and climate', Nature, 472: 429-36.

Beal, L. M., and S. Elipot. 2016. 'Broadening not strengthening of the Agulhas Current since the early 1990s', Nature, doi:10.1038/nature19853.

Beal, L. M., S. Elipot, A. Houk, and G. M. Leber. 2015. 'Capturing the transport variability of a western boundary jet: results from the Agulhas Current time-series experiment (ACT)', Journal of Physical Oceanography, 45: 1302-24.

Bhattacharya, G. C., A. K. Chaubey, G. P. S. Murty, K. Srinivas, K. V. L. N. S. Sarma, V. Subrahmanyam, and K. S. Krishna. 1994. 'Evidence for seafloor spreading in the Laxmi Basin, northeastern Arabian Sea', Earth and Planetary Science Letters, 125: 211-20.

Biastoch, A., and C. W. Boning. 2013. 'Anthropogenic impact on Agulhas leakage', Geophysical Research Letters, 40: 1138-43.

Biogeochemical-Argo_Planning_Group. 2016. "The Scientific Rationale, Design and Implementation Plan for a Biogeochemical-Argo Float Array." In, edited by K. Johnson and H. Claustre. doi:10.13155/46601.

Bown, J. W., and R. S. White. 1994. 'Variation with spreading rate of oceanic crustal thickness and geochemistry', Earth and Planetary Science Letters, 121: 435-49.

Brierley, A. S., and M. J. Kingsford. 2009. 'Impacts of climate change on marine organisms and ecosystems', Current Biology, 19: R602-R14.

Bryden, H. L., and L. M. Beal. 2001. 'Role of the Agulhas Current in Indian Ocean circulation and associated heat and freshwater fluxes', Deep Sea Research Part I, 48: 1821-45. 
Bryden, H. L., L. M. Beal, and L. M. Duncan. 2005. 'Structure and transport of the Agulhas Current and its temporal variability', Journal of Oceanography, 61: 47992.

Cai, W., T. Cowan, M. Dix, L. Rotstayn, J. Ribbe, G. Shi, and S. Wijffels. 2007. 'Anthropogenic aerosol forcing and the structure of temperature trends in the southern Indian Ocean', Geophysical Research Letters, 34, doi: 0.1029/2007GL030380.

Chatterjee, P., and B. N. Goswami. 2004. 'Structure, genesis and scale selection of the tropical quasi-biweekly mode', Quarterly Journal of the Royal Meteorological Society, 130: 1171-94.

Cheng, L., K. Trenberth, J. Fasullo, T. Boyer, J. Abraham, and J. Zhu. 2017. 'Improved estimates of ocean heat content from 1960 to 2015', Science Advances, 3: e1601545.

Codispoti, L., J. A. Brandes, J. Christensen, A. Devol, S. Naqvi, H. W. Paerl, and T. Yoshinari. 2001. 'The oceanic fixed nitrogen and nitrous oxide budgets: Moving targets as we enter the anthropocene?', Scientia Marina (Barcelona), 65, suppl. 2: 85-105.

Conkright, M. E., R. A. Locarnini, H. E. Garcia, T. D. O'Brien, T. P. Boyer, C. Stephens, and J. I. Antonov. 2002. "World Ocean Atlas 2001: Objective Analyses, Data Statistics, and Figures, CD-ROM Documentation." In, 17. National Oceanographic Data Center, Silver Spring, MD.

Dong, L., and T. J. Zhou. 2014. 'The Indian Ocean sea surface temperature warming simulated by CMIP5 models during the 20th century: Competing forcing roles of GHGs and anthropogenic aerosols', Journal of Climate, 27: 3348-62.

Feng, M., C. Boning, A. Biastoch, E. Behrens, E. Weller, and Y. Masumoto. 2011. 'The reversal of the multi-decadal trends of the equatorial Pacific easterly winds, and the Indonesian Throughflow and Leeuwin Current transports', Geophysical Research Letters, 38.

Feng, M., G. Meyers, A. Pearce, and S. Wijffels. 2003. 'Annual and interannual variations of the Leeuwin Current', Journal of Geophysical Research, Oceans, 108: 3355-76.

Feng, M., D. Susanto, H. Phillips, and L. Beal. 2017. 'Oceanic fluxes: boundary currents and Indonesian Throughflow', IndOOS Review white paper, Chapter 9.

Ferrari, R. , and D. Ferreira. 2011. 'What processes drive the ocean heat transport', Ocean Modelling, 38: 171-86.

Ffield, A., and A. L. Gordon. 1996. 'Tidal mixing signatures in the Indonesian seas', Journal of Physical Oceanography, 26: 1924-37.

Findlater, J. 1969. 'A major low-level air current near the Indian Ocean during the northern summer ', Quarterly Journal of the Royal Meteorological Society, 95: $362-80$.

Foltz, G., J. Vialard, P. Kumar, and M. J. McPhaden. 2010. 'Seasonal mixed layer heat balance of the southwestern tropical Indian Ocean', Journal of Climate, 23: 94765.

Fonteneau, A., V. Lucas, E. Tewkai, A. Delgado, and H. Demarcq. 2008. 'Mesoscale exploitation of a major tuna concentration in the Indian Ocean', Aquatic Living Resources, 21: 109-21.

Funk, C., M. D. Dettinger, J. C. Michaelsen, J. P. Verdin, M. E. Brown, M. Barlow, and A. Hoell. 2008. 'Warming of the Indian Ocean threatens eastern and southern 
African food security but could be mitigated by agricultural development', Proceedings of the Indian Academy of Sciences-Earth and Planetary Sciences, 105: 11081-86.

Gadgil, S. 2003. 'The Indian Monsoon and Its Variability', Annual Review of Earth and Planetary Science, 31: 429-67.

Galy, V., C. France-Lanord, O. Beyssac, P. Faure, H. Kudrass, and F. Palhol. 2007. 'Efficient organic carbon burial in the Bengal fan sustained by the Himalayan erosional system', Nature, 450: 407-10.

Goes, J. I., P.G. Thoppil, H. D. Gomes, and J. T. Fasullo. 2005. 'Warming of the Eurasian landmass is making the Arabian Sea more productive', Science, 308: $545-47$.

Gomes, H. D., J. I. Goes, S. G. P. Motondkar, E. J. Buskey, S. Basu, S. Parab, and P. G. Thoppil. 2014. 'Massive outbreaks of Notiluca scintillans blooms in teh Arabian Sea due to spread of hypoxia', Nature Communications, 5: http://dx.doi.org/10.1038/ncomms5862.

Gomes, H. R. , S. G. Prabhu Matondkar, S. G. Parab, J. I. Goes, S. Pednekar, A. R. N. Al-Azri, and P.G. Thoppil. 2009. 'Unusual blooms of green Noctiluca miliaris (Dinophyceae) in the Arabian Sea.' in J. D. Wiggert, R. R. Hood, S. W. A. Naqvi, K. H. Brink and S. L. Smith (eds.), Indian Ocean Biogeochemical Processes and Ecological Variability (American Geophysical Union: Washington, D.C., USA).

Gordon, A. L. 1985. 'Indian-Atlantic transfer of thermocline water at the Agulhas retroflection', Science, 227: 1030-33.

Goswami, B. N., V. Venugopal, D. Sengupta, M. S. Madhusoodanan, and P. K. Xavier. 2006. 'Increasing trend of extreme events over India in a warming environment', Science, 314: 1442-45.

Gruber, N. 2011. 'Warming up, turning sour, losing breath: Ocean biogeochemistry under global change', Philosophical Transactions of the Royal Society of London Series A - Mathematical, Physical and Engineering Sciences, 369: 546-50.

Halpern, B. S., C. Longo, D. Hardy, K. L. McLeod, J. F. Samhouri, S. K. Katona, K. Kleisner, S. E. Lester, J. O'Leary, M. Ranelletti, A. A. Rosenberg, C. Scarborough, E. R. Selig, B. D. Best, D. R. Brumbaugh, F. S. Chapin, L. B. Crowder, K. L. Daly, S. C. Doney, C. Elfes, M. J. Fogarty, S. D. Gaines, K. I. Jacobsen, L. B. Karrer, H. M. Leslie, E. Neeley, D. Pauly, S. Polasky, B. Ris, K. St. Martin, G. S. Stone, U. Sumaila, and D. Zeller. 2012. 'An index to assess the health and benefits of the global ocean', Nature, 488: 615-20.

Han, W. , J. Vialard, M. J. McPhaden, T. Lee, Y. Masumoto, M. Feng, and W. P. de Ruiter. 2014. 'Indian Ocean decadal variability: A review', Bulletin of the American Meteorological Society, 95: 1679-703.

Han, W. Q., G. A. Meehl, B. Rajagopalan, J. T. Fasullo, A. Hu, and J. Lin. 2010. 'Patterns of Indian Ocean sea-level change in a warming climate', Nature Geoscience, 3: 546-50.

Hartmann, D. L., and H. H. Hendon. 2007. 'Resolving and atmospheric enigma', Science, 318(5857):1731-1732.

Hatayama, T. 2004. 'Transformation of the Indonesian throughflow water by vertical mixing and its relation to tidally generated internal waves', Journal of Oceanography, 60: 569-85. 
Hermes, J. C., and C. J. C. Reason. 2008. 'Annual cycle of the South Indian Ocean (Seychelles-Chagos) thermocline ridge in a regional ocean model', Journal of Geophysical Research, 113: C04035, doi:10.1029/2007JC004363.

Hernandez-Guerra, A., and L. D. Talley. 2016. 'Meridional overturning transports at $30 \mathrm{~S}$ in the Indian and Pacific Oceans in 2002-2003 and 2009', Progress in Oceanography, 146.

Hood, R. R. , H. W. Bange, L. Beal, L. E. Beckley, P. Burkill, G. L. Cowie, N. D'Adamo, G. Ganssen, H. Hendon, J. Hermes, M. Honda, M. McPhaden, M. Roberts, S. Singh, E. Urban, and W. Yu. 2015. "Science Plan of the Second International Indian Ocean Expedition (IIOE-2): A Basin-Wide Research Program." In. Newark, Delaware, USA: Scientific Committee on Oceanic Research.

IOTC. 2017. 'Report of the 21st Session of the Indian Ocean Tuna Commission ', Yogyakarta, Indonesia, IOTC-2017-S21-R[E]: $114 \mathrm{pp}$.

IPC. 2015. "Implementation Strategy for the Second International Indian Ocean Expedition." In Written by: UNESCO IOC IIOE-2 Interim Planning Committee (Group of Experts), edited by N D'Adamo. Paris, France.

IPCC. 2007. 'Contribution of Working Groups I, II and III to the Fourth Assessment Report of the Intergovernmental Panel on Climate Change.' in Core_Writing_Team, R. K. Pachauri and A. Reisinger (eds.) (IPCC: Geneva, Switzerland).

Izumo, T., C. de Boyer Montegut, J. J. Luo, S. K. Behera, S. Masson, and T. Yamagata. 2008. 'The role of the western Arabian Sea upwelling in Indian monsoon rainfall variability', Journal of Climate, 21: 5603-23.

Jena, B., S. Sahu, K. Avinash, and D. Swain. 2013. 'Observation of oligotrophic gyre variability in the south Indian Ocean: environmental forcing and biological response', Deep Sea Research Part I, 80: 1-10.

Jia, F., H. Zhou, Q. Yang, H. Gao, H. Wan, and M. Lilley. 2017. 'Geochemistry of hydrothermal vent fluids and its implications for subsurface processes at the active Longqi hydrothermal field, Southwest Indian Ridge', Deep Sea Research I, 122: $41-47$.

Johns, W. , M. O. Baringer, L. M. Beal, S. A. Cunniingham, T. Kanzow, H. L. Bryden, M. Hirschi, J. Marotzke, C. S. Meinen, B. Shaw, and R. Curry. 2011. 'Continuous, array-based estimates of Atlantic Ocean heat transport at $26.5 \mathrm{~N}$. ', Journal of Climate, 23: 2429-49.

Kallmeyer, J. , R. Pockalny, R. R. Adhikari, D. C. Smith, and S. D'Hondt. 2012. 'Global distribution of microbial abundance and biomass in subseafloor sediment. ', Proceedings of the National Academy of Sciences of the United States of America, 109: 16213-16.

Kanzow, T., S. A. Cunningham, W. E. Johns, J. J. Hirschi, J. Marotzke, M. O. Baringer, C. S. Meinen, M. P. Chidichimo, C. Atkinson, L. M. Beal, H. L. Bryden, and J. Collins. 2010. 'Seasonal variability of the Atlantic meridional overturning circulation at $26.5 \mathrm{~N}$. ', Journal of Climate, 23: 5678-98.

Katsumata, K., and S. Masuda. 2013. 'Variability in Southern Hemisphere Ocean Circulation from the 1980s to the 2000s. Journal of Physical Oceanography', Journal of Physical Oceanography, 43: 1981-2007.

Kinzer, J., R. Bottgerschnack, and K. Schulz. 1993. 'Aspects of horizontal distribution and diet of myctophid fish in the Arabian Sea with reference to the deep-water oxygen deficiency', Deep Sea Research Part II, 40: 783-800. 
Koch-Larrouy, A., M. Lengaigne, P. Terray, G. Madec, and S. Masson. 2010. 'Tidal mixing in the Indonesian Seas and its effect on the tropical climate system', Climate Dynamics, 34: 891-904.

Kone, V., O. Aumont, M. Levy, and L. Resplandy. 2009. 'Physical and biogeochemical controls of the phytoplankton seasonal cycle in the Indian Ocean: A modeling study.' in J. D. Wiggert, R. R. Hood, S. W. A. Naqvi, K. H. Brink and S. L. Smith (eds.), Indian Ocean Biogeochemical Processes and Ecological Variability (American Geophysical Union: Washington, DC).

Krishna, K. S., J. M. Bull, and R. A. Scrutton. 2001. 'Evidence for multiphase folding of the central Indian Ocean lithosphere', Geology, 29.

- 2009. 'Early (pre-8 Ma) fault activity and temporal strain accumulation in the central Indian Ocean', Geology, 37: 227-30.

Krishna, K. S., D. Gopala Rao, and D. Sar. 2006. 'Nature of the crust in the Laxmi Basin (14-20N), western continental margin of India', Techtonics, 25: TC1006.

Kumar, Dileep, M., S.W.A. Naqvi, M. D. George, and A. Jayakumar. 1996. 'A sink for atmospheric carbon dioxide in the northeastern Indian Ocean', Journal of Geophysical Research, 101: 18,121 - 18,25.

Lawrence, D. M., and P. J. Webster. 2002. 'The boreal summer intraseasonal oscillation: Relationship between northward and eastward movement of convection', Journal of the Atmospheric Sciences, 59: 1593-606.

Lee, S-K., W. Park, M. O. Baringer, A. Gordon, B. Huber, and Y. Liu. 2015. 'Pacific origin of the abrupt increase in Indian Ocean heat content during the warming hiatus', Nature Geoscience, 8: 445-50.

Lee, T. 2004. 'Decadal weakening of the shallow overturning circulation in the South Indian Ocean', Geophysical Research Letters, 31.

Lee, T., and M. J. McPhaden. 2008. 'Decadal phase change in large-scale sea level and winds in the Indo-Pacific region at the end of the 20th century', Geophysical Research Letters, 35: L01605, doi:10.1029/2007GL032419.

Lévy, M., D. Shankar, J. M. André, S. S. C. Shenoi, F. Durand, and C. D. B. Montégut. 2007. 'Basin-wide seasonal evolution of the Indian Ocean's phytoplankton blooms', Journal of Geophysical Research, 112: doi:10.1029/2007JC004090.

$\mathrm{Li}$, J. P., and Q. C. Zeng. 2003. 'A new monsoon index, its interannual variability and relation with monsoon precipitation', Climatic and Environmental Research, 10: 351-65.

Liu, Q. Y., M. Feng, D. Wang, and S. Wijffels. 2015. 'Interannual variability of the Indonesian Throughflow transport: A revisit based on 30 year expendable bathythermograph data', Journal of Geophysical Research, Oceans, 120: 827082.

Loveday, B., P. Penven, and C. J. C. Reason. 2015. 'Southern Annular Mode and westerly-wind-driven changes in Indian-Atlantic exchange mechanisms', Geophysical Research Letters, 42: 4912-21.

Lumpkin, R., and K. Speer. 2007. 'Global ocean meridional overturning', Journal of Physical Oceanography, 37: 2550-62.

Lutjeharms, J. R. E., and T. G. Bornman. 2010. 'The importance of the greater Agulhas Current is increasingly being recognised', South African Journal of Science, 106: $1-4$. 
Madden, R. A., and P. R. Julian. 1972. 'Description of global-scale circulation cells in the tropics with a 40-50 day period', Journal of Atmospheric Sciences, 29: 110923.

McCarthy, G. D., D. A. Smeed, W. E. Johns, E. Frajka-Williams, B. I. Moat, D. Rayner, M. O. Baringer, C. S. Meinen, J. Collins, and H. L. Bryden. 2015. 'Measuring the Atlantic meridional overturning circulation at $26 \mathrm{~N}$ ', Progress in Oceanography, 130: 91-111.

McClanahan, T. R., M. Ateweberhan, N. A. J. Graham, S. K. Wilson, C. R. Sebastian, M. M. M. Guillaume, and J. H. Bruggemann. 2007. 'Western Indian Ocean coral communities: bleaching responses and susceptibility to extinction', Marine Ecology Progress Series, 337: 1-13.

McClanahan, T. R., M. Ateweberhan, C. R. Sebastian, N. A. J. Graham, S. K. Wilson, J. H. Bruggemann, and M. M. M. Guillaume. 2007. 'Predictability of coral bleaching from synoptic satellite and in situ temperature observations', Coral Reefs, 26: 695-701.

McCreary, J. P., Z. Yu, R. R. Hood, P. N. Vinayachandran, R. Furue, A. Ishida, and K. J. Richards. 2013. 'Dynamcis of the Indian-Ocean oxygen minumum zones', Progress in Oceanography, 112-113: 15-37.

McDonagh, E. L., H. L. Bryden, B. A. King, and R. J. Sanders. 2008. 'The circulation of the Indian Ocean at 32 S', Progress in Oceanography, 79: 20-36.

McPhaden, M. J., H. W. Kang, R. Anderson, R. Hood, S. H. Choi, C. J. Jang, D. J. Kang, Y. H. Lee, S. Nam, T. Rho, U. Send, J. Wiggert, and U. Yi. 2018. 'A KoreaUS inDian Ocean Scientific (KUDOS) Research Program on the Physical, Biogeochemical and Ecological Dynamics of the Seychelles-Chagos Thermocline Ridge', Report from a workshop held at Seoul National University over 29 November to 1 December 2017, 26 pp.: Available at: https://kiost-noaalab.wixsite.com/kudos2018/logistic-information.

McPhaden, M. J., G. Meyers, K. Ando, Y. Masumoto, V. S. N. Murty, M. Ravichandran, F. Syamsudin, J. Vialard, L. Yu, and W. Yu. 2009. 'RAMA: The Research Moored Array for African-Asian-Australian Monsoon Analysis and Prediction*', Bulletin of the American Meteorological Society, 90: 459-80.

McPhaden, M. J., and M. Nagura. 2014. 'Indian Ocean dipole interpreted in terms of recharge oscillator theory', Climate Dynamics, 42: 1569-86.

Moffett, J. W., J. Vedamati, T. J. Goepfert, A. Pratihary, M. Gauns, and S. W. A. Naqvi. 2015. 'Biogeochemistry of iron in the Arabian Sea', Limnology and Oceanography, 60: 1671-88.

Moore, J. A., L. M. Bellchambers, M. R. Depczynski, R. D. Evans, S. N. Evans, S. N. Field, K. J. Friedman, J. P. Gilmour, T. H. Holmes, R. Middlebrook, B. T. Radford, T. Ridgway, G. Shedrawi, H. Taylor, D. P. Thompson, and S. K. Wilson. 2012. 'Unprecedented mass bleaching and loss of coral across 12 degrees of latitude in Western Australia in 2010-11', PloS ONE, 7: e51087, doi:10.1317/journal.pone.0051807.

Nagai, T. , and T. Hibiya. 2015. 'Internal tides and associated vertical mixing in the Indonesian Archipelago', Journal of Geophysical Research, 120: 3373-90.

Naqvi, S. W. A. 1987. 'Some aspects of the oxygen-deficient conditions and denitrification in the Arabian Sea', Journal of Marine Research, 45: 1049-72. 
Naqvi, S. W. A. , P. V. Narvekar, and E. Desa. 2006. 'Coastal biogeochemical processes in the North Indian Ocean.' in A. Robinson and K. Brink (eds.), The Sea (Harvard University Press).

Naqvi, S. W. A., D. A. Jayakumar, P. V. Narvekar, H. Naik, Vvss Sarma, W. D'Souza, S. Joseph, and M. D. George. 2000. 'Increased marine production of $\mathrm{N}_{2} \mathrm{O}$ due to intensifying anoxia on the Indian continental shelf', Nature, 408: 346-49.

Naqvi, S. W. A., H. Naik, A. Jayakumar, A. Pratihary, G. Narvenkar, S. Kurian, R. Agnihotri, M. S. Shailaja, and P. V. Narvekar. 2009. 'Seasonal anoxia over the western Indian continental shelf.' in J. D. Wiggert, R. R. Hood, S. W. A. Naqvi, S. L. Smith and K. H. Brink (eds.), Indian Ocean Biogeochemical Processes adn Ecological Variability (American Geophysical Union: Washington, DC).

Nieves, V. , J. K. Willis, and W. C. Patzert. 2017. 'Recent hiatus caused by decadal shift in Indo-Pacific heating', Science, 349: 532-35.

Nugroho, D., A. Koch-Larrouy, F. Lyard, G. Reffray, P. Gaspar, and B. Tranchant. 2017. 'Modelling explicit tides in the Indonesian seas: An important process for surface seawater properties', Marine Pollution Bulletin, 12: 16.

Obura, D., et al. 2015. 'Reviving the Western Indian Ocean Economy: Actions for a Sustainable Future', WWF International, Gland, Switzerland: 64 pp.

Pathak, A., S. Ghosh, P. Kumar, and R. Murtugudde. 2017. 'Role of oceanic and terrestrial atmospheric moisture sources in intraseasonal variability of Indian summer monsoon rainfall', Scientific Reports, 7: 1-11.

Peeters, F. J. , R. Acheson, G.-J. A. Brummer, W. P. M. de Ruiter, R. R. Schneider, G. M. Ganssen, E. Ufkes, and D. Kroon. 2004. 'Vigorous exchange between the Indian and Atlantic oceans at the end of the past five glacial periods', Nature, 430: 661-65.

Potemra, J. 2005. 'Indonesian Throughflow transport variability estimated from satellite altimetry', Oceanography, 18: doi:10.5670/oceanog.2005.10.

Potemra, J. T., R. Lukas, and G. T. Michum. 1997. 'Large-scale estimation of transport from the Pacific to the Indian Ocean', Journal of Geophysical Research - Oceans, 102: 27,795-27,812, doi:1.1029/97JC01719.

Rashid, T., S. Hoque, and F. Akter. 2013. 'Ocean acidification in the Bay of Bengal', Scientific Reports, 2: 699.

Ray, R., and R. D. Susanto. 2016. 'Tidal mixing signatures in the Indonesian seas from high-resolution sea-surface temperature ', Geophysical Research Letters, 43: doi:10.1002/ 2016GL069485.

Resplandy, L., M. Levy, G. Madec, S. Pous, O. Aumont, and D. Kumar. 2011. 'Contribution of mesoscale processes to nutrient budgets in the Arabian Sea', Journal of Geophysical Research, 116: C11007.

Resplandy, L., J. Vialard, M. Lévy, O. Aumont, and Y. Dandoneau. 2009. 'Seasonal and intraseasonal biogeochemical variability in the thermocline ridge of the Indian Ocean', Journal of Geophysical Research, 114: C07024, doi:10.29/2008JC005246.

Robbins, P. E., and J. M. Toole. 1997. 'The dissolved silica budget as a constraint on the meridional overturning circulation of the indian ocean', Deep Sea Research Part I, 44: 879-906.

Roberts, C. D., M. D. Palmer, R. P. Allan, D. G. Desbruyeres, P. Hyder, C. Liu, and D. Smith. 2017. 'Surface flux and ocean heat transport convergence contributions to 
seasonal and interannual variations of ocean heat content', Journal of Geophysical Research, 122: 726-44.

Robinson, A. R., P. Guillotreau, R. Jimenez-Toribio, F. Lantz, L. Nadzon, J. Dorizo, C. Gerry, and F. Marsac. 2010. 'Impacts of climate variability on the tuna economy of Seychelles', Climate Research, 43: 149-62.

Roxy, M. K., A. Modi, R. Murtugudde, V. Valsala, S. Panickal, S. P. Kumar, M. Ravichandran, M. Vichi, and M. Levy. 2016. 'A reduction in marine primary productivity driven by rapid warming over the tropical Indian Ocean', Geophysical Research Letters, 43: 826-33.

Royer, J. Y., and R. G. Gordon. 1997. 'The motion and boundary between the Capricorn and Australian plates', Science, 277: 1268-74.

Sager, W. W., J. M. Bull, and K. S. Krishna. 2013. 'Active faulting on the Ninetyeast Ridge and its relation to deformation of the Indo-Australian plate', Journal of Geophysical Research Solid Earth, 118.

Saji, N. H., B. N. Goswami, P. N. Vinayachandran, and T. Yamagata. 1999. 'A dipole mode in the tropical Indian Ocean', Nature, 401: 360-63.

Sandwell, D. T., R. D. Muller, W. H. F. Smith, E. Garcia, and R. Francis. 2014. 'New global marine gravity model from CryoSat-2 and Jason-1 reveals buried tectonic structure', Science, 346: 65-67.

Schoenefeldt, R., and F. A. Schott. 2006. 'Decadal variability of the Indian Ocean crossequatorial exchange in SODA', Geophysical Research Letters, 33.

Schott, F. A., and J. P. McCreary. 2001. 'The monsoon circulation in the Indian Ocean', Progress in Oceanography, 51: 1-123.

Sen Gupta, A., S. McGregor, E. van Sebille, A. Ganachaud, J. N. Brown, and A. Santoso. 2016. 'Future changes to the Indonesian Throughflow and Pacific circulation: The differing role of wind and deep circulation changes', Geophysical Research Letters, 43: 1669-78.

Sibuet, J. C. , F. Klingelhoefer, Y-P. Huang, Yi-C. Yeh, C. Rangin, C-S. Lee, and S-K. Hsu. 2016. 'Thinned continental crust intruded by volcanics beneath the northern Bay of Bengal', Marine and Petroleum Geology, 77: 471-86.

Sibuet, J. C., F. Klingelhoefer, Yi-C. Yeh, C. Rangin, and C-S. Lee. 2017. 'Reply to the comment of Talwani et al. (2017) on the Sibuet et al. (2016) paper entitled "Thinned continental crust intruded by volcanics beneath the northern Bay of Bengal'", Marine and Petroleum Geology, 88: 1126-29.

Singh, S. C. , N. Hananto, Y. Qin, F. Leclerc, P. Avianto, P. E. Tapponnier, H. Carton, S. Wei, A. B. Nugroho, W. A. Gemilang, K. Sieh, and S. Barbot. 2017. 'The discovery of a conjugate system of faults in the Wharton Basin intraplate deformation zone', Science Advances, 3: e1601689.

Souza, J. M. A. C., C. de Boyer Montegut, C. Cabanes, and P. Klein. 2011. 'Estimation of the Agulhas ring impacts on meridional heat fluxes and transport using ARGO floats and satellite data', Geophysical Research Letters, 38: L21602.

Sprintall, J., A. L. Gordon, A. Koch-Larrouy, T. Lee, J. T. Potemra, K. Pujiana, and S. E. Wijffels. 2014. 'The Indonesian seas and their role in the coupled ocean-climate system', Nature Geoscience, 7: 487-92, doi:10.1038/ngeo2188.

- 3014. 'The Indonesian seas and their role in the coupled ocean-climate system', Nature Geoscience, 7: 487-92.

Sprintall, J., and A. Revelard. 2014. 'The Indonesian Throughflow response to IndoPacific climate variability', Journal of Geophysical Research, 119: 1161-75. 
Stramma, L., G. C. Johnson, J. Sprintall, and V. Mohrholz. 2008. 'Expanding oxygenminimum zones in the tropical oceans,' Science, 320: 655-58.

Stramma, L., S. Schmidtko, L. A. Levin, and G. C. Johnson. 2010. 'Ocean oxygen minima expansions and their biological impacts', Deep-Sea Research, Part I, 57: 587-95.

Susanto, R. D., A. Ffield, A. Gordon, and T. R. Adi. 2012. 'Variability of the Indonesian throughflow', Journal of Geophysical Research - Oceans, 117: doi:10.1029/2012JC008096.

Susanto, R. D., A. L. Gordon, and J. Sprintall. 2007. 'Observations and proxies of the surface layer throughflow in Lombok Strait', Journal of Geophysical Research Oceans, 112: C03S92, doi:10.1029/2006JC003790.

Susanto, R. D., and Y. T. Song. 2015. 'Indonesian throughflow proxy from satellite altimeters and gravimeters', Journal of Geophysical Research, 120: 2844-55.

Susanto, R. D., Z. Wei, T. R. Adi, Q. Zheng, G. Fang, B. Fan, A. Supangat, T. Agustiadi, S. Li, M. Tenggono, and A. Setiawan. 2016. 'Oceanography surrounding Krakatau Volcano in the Sunda Strait, Indonesia', Oceanography, 29: 264-72.

Takahashi, T., S.C. Sutherland, C. Sweeney, A. Poisson, N. Metzl, B. Tilbrook, N. Bates, R. Wanninkhof, R.A. Feely, C. Sabine, J. Olafsson, and Y. Nojiri. 2002. 'Global sea-air $\mathrm{CO}_{2}$ flux based on climatological surface ocean $\mathrm{pCO}_{2}$, and seasonal biological and temperature effects', Deep-Sea Research Part II, 49: 1601-23.

Talley, L. D. 2003. 'Shallow, intermediate, and deep overturning components of the global heat budget', Journal of Physical Oceanography, 33: 530-60.

- 2013. 'Closure of the global overturning circulation through the Indian, Pacific and Southern Oceans: Schematics and transports', Oceanography, 26: 80-97.

Talley, L. D., G. L. Pickard, W. J. Emery, and J. H. Swift. 2011. Descriptive Physical Oceanography: An Introduction (Elsevier: New York).

Talley, L. D., and J. Sprintall. 2005. 'Deep expression fo the Indonesian Throughflow: Indonesian Intermediate Water in the South Equatorial Current', Journal of Geophysical Research, Oceans, 110.

Talwani, M. , and C. Reif. 1998. 'Laxmi Ridge-A continental sliver in the Arabian Sea', Marine Geophysical Research, 20: 259-71.

Talwani, M., M. A. Desa, M. Ismaiel, and K. S. Krishna. 2016. 'The Tectonic origin of the Bay of Bengal and Bangladesh', Journal of Geophysical Research Solid Earth, 121: 4836-51.

Tao, C., J. Lin, S. Guo, Y. J. Chen, G. Wu, X. Han, C. R. German, D. R. Yoerger, N. Zhou, H. Li, X. Su, and J. Zhu. 2011. 'First active hydrothermal vents on an ultraslow-spreading center: Southwest Indian Ridge', Geology, 40: 47-50.

Todal, A., and O. Eldholm. 1998. 'Continental margin off western India and Deccan Large Igneous Province', Marine Geophysical Research, 20: 273-91.

Tsarin, S. A., and A. R. Boltachev. 2006. 'Mesopelagic fishes of the Arabian Sea.' in K. Banse and S. A. Piontkovski (eds.), The Mesoscale Structure of the Epipelagic Ecosystem of the Open Northern Arabian Sea (Universities Press (India): Hyderabad).

Turner, A. G., and H. Annamalai. 2012. 'Climate change and the South Asian summer monsoon', Nature Climate Change, 2: 587-95. 
Vialard, J., G. Foltz, M. J. McPhaden, J. P. Duvel, and C. de Boyer Montegut. 2008. 'Strong Indian Ocean sea surface temperature signals associated with the Madden-Julian oscillation in late 2007 and early 2008', Geophysical Research Letters, 35: L19608, doi:10.1029/2008GL035238.

Vialard, J., J. P. Duvel, M. McPhaden, P. Bouruet-Aubertot, B. Ward, E. Key, D. Bourras, R. Weller, P. Minnett, A. Weill, C. Cassou, L. Eymard, T. Fristedt, C. Basdevant, Y. Dandoneau, O. Duteil, T. Izumo, C. de Boyer Montégut, S. Masson, F. Marsac, C. Menkes, and S. Kennan. 2009. 'Cirene: Air-sea interactions in the Seychelles-Chagos thermocline ridge region', Bulletin of the American Meteorological Society, 90: 45-61.

Vranes, K., A. L. Gordon, and A. Ffield. 2002. 'The heat transport of the Indonesian Throughflow and implications for the Indian Ocean heat budget', Deep Sea Research Part II, 49: 1391-410.

Wang, Y. , and M. J. McPhaden. 2017. 'Seasonal cycle of cross-equatorial flow in the central Indian Ocean', Journal of Geophysical Research, 122: doi:10.1002/2016JC012537.

Ward, B. B., A. H. Devol, J. J. Rich, B. X. Chang, S. E. Bulow, Hema Naik, Anil Pratihary, and A. Jayakumar. 2009. 'Denitrification as the dominant nitrogen loss process in the Arabian Sea', Nature, 461: 78-81.

Watson, P. J. 2011. 'Is there evidence yet of acceleration in mean sea level rise around mainland Australia? ', Journal of Coastal Research, 27: 368-77.

Webster, P. J., G. J. Holland, J. A. Curry, and H. R. Chang. 2005. 'Changes in tropical cyclone number, duration, and intensity in a warming environment', Science, 309: 1844-46.

Webster, P. J., A. M. Moore, J. P. Loschnigg, and R. R. Leben. 1999. 'Coupled oceanatmosphere dynamics in the Indian Ocean during 1997-98', Nature, 401: 356-60.

Wheeler, M. , and G. N. Kiladis. 1999. 'Convectively coupled equatorial waves: Analysis of clouds and temperature in the wavenumber-frequency domain', Journal of Atmospheric Sciences, 56: 374-99.

Wiggert, J. D., and R. G. Murtugudde. 2007. 'The sensitivity of the Southwest Monsoon phytoplankton bloom to variations in aeolian iron deposition over the Arabian Sea', Journal of Geophysical Research, 112: doi:10.1029/2006JC003514.

Wiggert, J. D., R. G. Murtugudde, and J. R. Christian. 2006. 'Annual ecosystem variability in the tropical Indian Ocean: Results of a coupled bio-physical ocean general circulation model', Deep-Sea Research, Part II, 53: 644-76.

Wu, L., W. Cai, L. Zhang, H. Nakamura, A. Timmermann, T. Joyce, M. J. Mcphaden, M. Alexander, B. Qiu, M. Visbeck, P. Chang, and B. Giese. 2012. 'Enhanced warming over the global subtropical western boundary currents', Nature Climate Change, 2: 161-66.

Xie, S. P., H. Annamalai, F. A. Schott, and J. P. McCreary. 2002a. 'Origin and predictability of South Indian Ocean climate variability', Journal of Climate, 15: 864-74.

2002b. 'Structure and mechanisms of South Indian Ocean climate variability', Journal of Climate, 15: 874-78.

Yan, X. H., T. Boyer, K. Trenberth, T. R. Karl, S. P. Xie, V. Nieves, K. K. Tung, and D. Roemmich. 2016. 'The global warming hiatus: Slowdown or redistribution', Earth Future, doi:10.1002/2016EF000417. 
Yang, H. , G. Lohmann, W. Wei, M. Dima, M. Ionita, and J. Liu. 2016. 'Intensification and poleward shift of subtropical western boundary currents in a warming climate', Journal of Geophysical Research, 121: 4928-45.

Yokoi, T., T. Tozuka, and T. Yamagata. 2008. 'Seasonal variations of the Seychelles Dome', Journal of Climate, 21: 3740-54.

Zhang, C. , and J. Ling. 2017. 'Barrier effect of the Indo-Pacific Maritime Continent: Perspectives from tracking MJO precipitation', Journal of Climate, 30: 3439-59.

Zhang, C. D. . 2013. 'Madden-Julian Oscillations bridging weather and climate', Bulletin of the American Meteorological Society, December 2013: 1849-70.

Zhang, R. , and T. L. Delworth. 2006. 'Impact of Atlantic multidecadal oscillations on India/Sahel rainfall and Atlantic hurricanes', Geophysical Research Letters, 33: doi:10.1029/2006GL026267.

Zhao, and Di Lorenzo. 2017. 'The role of southern and northern hemisphere ENSO precursors in tropical Pacific decadal variability', in review.

Zhou, L., and R. Murtugudde. 2009. 'Ocean-atmosphere coupling on different spatiotemporal scales: A mechanism for intraseasonal instabilities', Journal of the Atmospheric Sciences, 66: 1834-44.

Zhou, L., R. Murtugudde, and M. Jochum. 2008a. 'Dynamics of the intraseasonal oscillations in the Indian Ocean South Equatorial current', Journal of Physical Oceanography, 38: 121-32.

2008b. 'Seasonal influence of Indonesian Throughflow in the Southwestern Indian Ocean', Journal of Physical Oceanography, 38: 1529-41.

\section{APPENDIX. ACRONYMS}

\section{SCIENTIFIC ACRONYMS}

\begin{tabular}{|l|l|}
\hline ADCP & Acoustic Doppler Current Profiler \\
\hline Argo & $\begin{array}{l}\text { An international program that uses profiling floats to } \\
\text { observe temperature, salinity, currents, and, recently, bio- } \\
\text { optical properties in the Earth's oceans }\end{array}$ \\
\hline AS & Arabian Sea \\
\hline AUV & Autonomous Underwater Vehicle \\
\hline AVHRR & Advanced Very High Resolution Radiometer (NOAA) \\
\hline BGC & Biogeochemical \\
\hline BoB & Bay of Bengal \\
\hline B-SOSE & biogeochemical Southern Ocean State Estimate \\
\hline CDOM & Colored Dissolved Organic Matter \\
\hline CTD & Conductivity/Temperature/Depth sensor \\
\hline DOI & Digital Object Identifier \\
\hline EEZ & Exclusive Economic Zone \\
\hline E-P & Evaporation minus Precipitation \\
\hline ETIO & Eastern Tropical Indian Ocean \\
\hline GPM & Global Precipitation Mission (NASA) \\
\hline GPS & Global Positioning System \\
\hline
\end{tabular}


U.S. Contributions to the Second International Indian Ocean Expedition (U.S. IIOE-2)

\begin{tabular}{|l|l|}
\hline HYCOM & Hybrid Coordinate Model \\
\hline IOD & Indian Ocean Dipole \\
\hline ISS RapidScat & $\begin{array}{l}\text { An International Space Station (ISS) borne scatterometer } \\
\text { for measuring wind speed and direction (NASA) }\end{array}$ \\
\hline ITF & Indonesian Through Flow \\
\hline ITCZ & Inter-Tropical Convergence Zone \\
\hline MAPR & $\begin{array}{l}\text { Self-contained instruments with temperature, pressure, } \\
\text { and nephelometer sensors }\end{array}$ \\
\hline MISO & Monsoon Intraseasonal Oscillation \\
\hline MJO & Madden-Julian Oscillation \\
\hline MOC & Meridional Overturning Circulation \\
\hline MODIS-Terra & $\begin{array}{l}\text { Moderate Resolution Imaging Spectroradiometer (Terra- } \\
\text { AM Equatorial Crossing; Aqua - PM Equatorial Crossing) } \\
\text { (NASA) }\end{array}$ \\
\hline MODIS-Aqua & Mid-Ocean Ridge Basalts \\
\hline NERB & Northeast Monsoon \\
\hline OMZ & Oxygen Minimum Zone \\
\hline OSSE & Observing System Simulation Experiments \\
\hline ROV & Remotely Operated Vehicle \\
\hline S2S & Subseasonal-to-Seasonal \\
\hline SCTR & Seychelles-Chagos Thermocline Ridge \\
\hline SeaWiFS & Sea-viewing Wide Field-of-view Sensor (NASA) \\
\hline SEC & South Equatorial Current \\
\hline SECC & South Equatorial Countercurrent \\
\hline SSH & Sea Surface Height \\
\hline SSS & Sea Surface Salinity \\
\hline SST & Sea Surface Temperature \\
\hline SWM & Southwest Monsoon \\
\hline SWTIO & Southwestern Tropical Indian Ocean \\
\hline TOPEX/Poseidon, Jason & Satellite Altimeters that measure SSH (NASA) \\
\hline XBT & Expendable Bathythermograph \\
\hline & \\
\hline
\end{tabular}

PROJECT, PROGRAM AND ORGANIZATIONAL ACRONYMS

\begin{tabular}{|l|l|}
\hline ASCA & Agulhas System Climate Array \\
\hline ASIRI & Air-Sea Interaction Regional Initiative (ONR) \\
\hline BCO-DMO & $\begin{array}{l}\text { Biological and Chemical Oceanography Data Management } \\
\text { Office (US NSF) }\end{array}$ \\
\hline BOBLME & Bay of Bengal Large Marine Ecosystem \\
\hline BOBOA & $\begin{array}{l}\text { Bay of Bengal Ocean Acidification Mooring (NOAA and } \\
\text { BOBLME) }\end{array}$ \\
\hline CLIVAR & \begin{tabular}{l} 
Climate Variability and Predictability (WCRP) \\
\hline CMIP5/6
\end{tabular} \\
\hline
\end{tabular}




\begin{tabular}{|c|c|}
\hline EAR & National Science Foundation Division of Earth Sciences (US) \\
\hline EIOURI & Eastern Indian Ocean Upwelling Research Initiative \\
\hline GEOTRACES & $\begin{array}{l}\text { A collaborative multi-national programme to investigate the } \\
\text { global marine biogeochemical cycles of trace elements and } \\
\text { their isotopes (SCOR) }\end{array}$ \\
\hline GOOS & Global Ocean Observing System \\
\hline GO-SHIP & $\begin{array}{l}\text { Global Oceans Ship-Based Hydrographic Investigations } \\
\text { Program }\end{array}$ \\
\hline IAN & Integration and Application Network \\
\hline IEDA & Interdisciplinary Earth Data Alliance \\
\hline IIOE-2 & $\begin{array}{l}\text { The Second International Indian Ocean Expedition (SCOR, } \\
\text { IOC, IOGOOS) }\end{array}$ \\
\hline IMBeR & $\begin{array}{l}\text { Integrated Marine Biosphere Research project (SCOR, } \\
\text { Future Earth) }\end{array}$ \\
\hline IndOOS & Indian Ocean Observing System \\
\hline InterRidge & $\begin{array}{l}\text { An international organization that promotes interdisciplinary, } \\
\text { international studies of oceanic spreading centers }\end{array}$ \\
\hline IOC & Intergovernmental Oceanographic Commission \\
\hline IODE & $\begin{array}{l}\text { International Oceanographic Data and Information Exchange } \\
\text { (IOC) }\end{array}$ \\
\hline IODP & International Ocean Discovery Program \\
\hline IOGOOS & Indian Ocean Global Ocean Observing System \\
\hline IUSSTF & Indo-US Science and Technology Forum \\
\hline JGOFS & Joint Global Ocean Flux Study (SCOR, IGBP) \\
\hline MISO-BOB & $\begin{array}{l}\text { Oceanic Control of Monsoon Intra-seasonal Oscillations in } \\
\text { the Tropical Indian Ocean and the Bay of Bengal (ONR) }\end{array}$ \\
\hline NASA & National Aeronautics and Space Administration (USA) \\
\hline NASCar & $\begin{array}{l}\text { Northern Arabian Sea Circulation-autonomous research } \\
\text { (ONR) }\end{array}$ \\
\hline NCEI & National Centers for Environmental Information (NOAA) \\
\hline NOAA & National Oceanic and Atmospheric Administration (USA) \\
\hline NSF & National Science Foundation (USA) \\
\hline OCB & Ocean Carbon Biogeochemistry Program (NSF, NASA) \\
\hline OCE & $\begin{array}{l}\text { National Science Foundation Division of Ocean Sciences } \\
\text { (USA) }\end{array}$ \\
\hline ONR & Office of Naval Research (USA) \\
\hline POGO & Partnership for Observation of the Global Oceans \\
\hline RAMA & $\begin{array}{l}\text { Research moored Array for African-Asian-Australian } \\
\text { Monsoon Analysis and Prediction }\end{array}$ \\
\hline SCOR & Scientific Committee on Oceanic Research \\
\hline $\mathrm{SIO}$ & Scripps Institution of Oceanography \\
\hline SOLAS & $\begin{array}{l}\text { Surface Ocean-Lower Atmosphere Study (SCOR, IGBP, } \\
\text { WCRP, iCACGP) }\end{array}$ \\
\hline UCAR & University Corporation for Atmospheric Research \\
\hline UNAVCO & $\begin{array}{l}\text { A data center that handles data management tasks for GPS } \\
\text { data and products }\end{array}$ \\
\hline WOCE & World Ocean Circulation Experiment (WCRP) \\
\hline
\end{tabular}

